\title{
National Register Eligibility Testing of Site 41B0184, Brazoria County, Texas
}

Richard B. Mahoney

Steve A. Tomka

Raba Kistner

Follow this and additional works at: https://scholarworks.sfasu.edu/ita

Part of the American Material Culture Commons, Archaeological Anthropology Commons, Environmental Studies Commons, Other American Studies Commons, Other Arts and Humanities Commons, Other History of Art, Architecture, and Archaeology Commons, and the United States History Commons

Tell us how this article helped you.

This Article is brought to you for free and open access by the Center for Regional Heritage Research at SFA ScholarWorks. It has been accepted for inclusion in Index of Texas Archaeology: Open Access Gray Literature from the Lone Star State by an authorized editor of SFA ScholarWorks. For more information, please contact cdsscholarworks@sfasu.edu. 


\section{National Register Eligibility Testing of Site 41B0184, Brazoria County, Texas}

\section{Licensing Statement}

This is a work produced for the Texas Department of Transportation (TxDOT) by the report producer. TxDOT and the report producer jointly own all rights, title, and interest in and to all intellectual property developed under TXDOT's contract with the report producer. The report may be cited and brief passages from this publication may be reproduced without permission provided that credit is given to both TxDOT and the report producer. Permission to reprint an entire chapter, section, figures or tables must be obtained in advance from either the Supervisor of the Archeological Studies Branch, Environmental Affairs Division, Texas Department of Transportation, 125 East 11th Street, Austin, Texas, 78701 or from the report producer. 


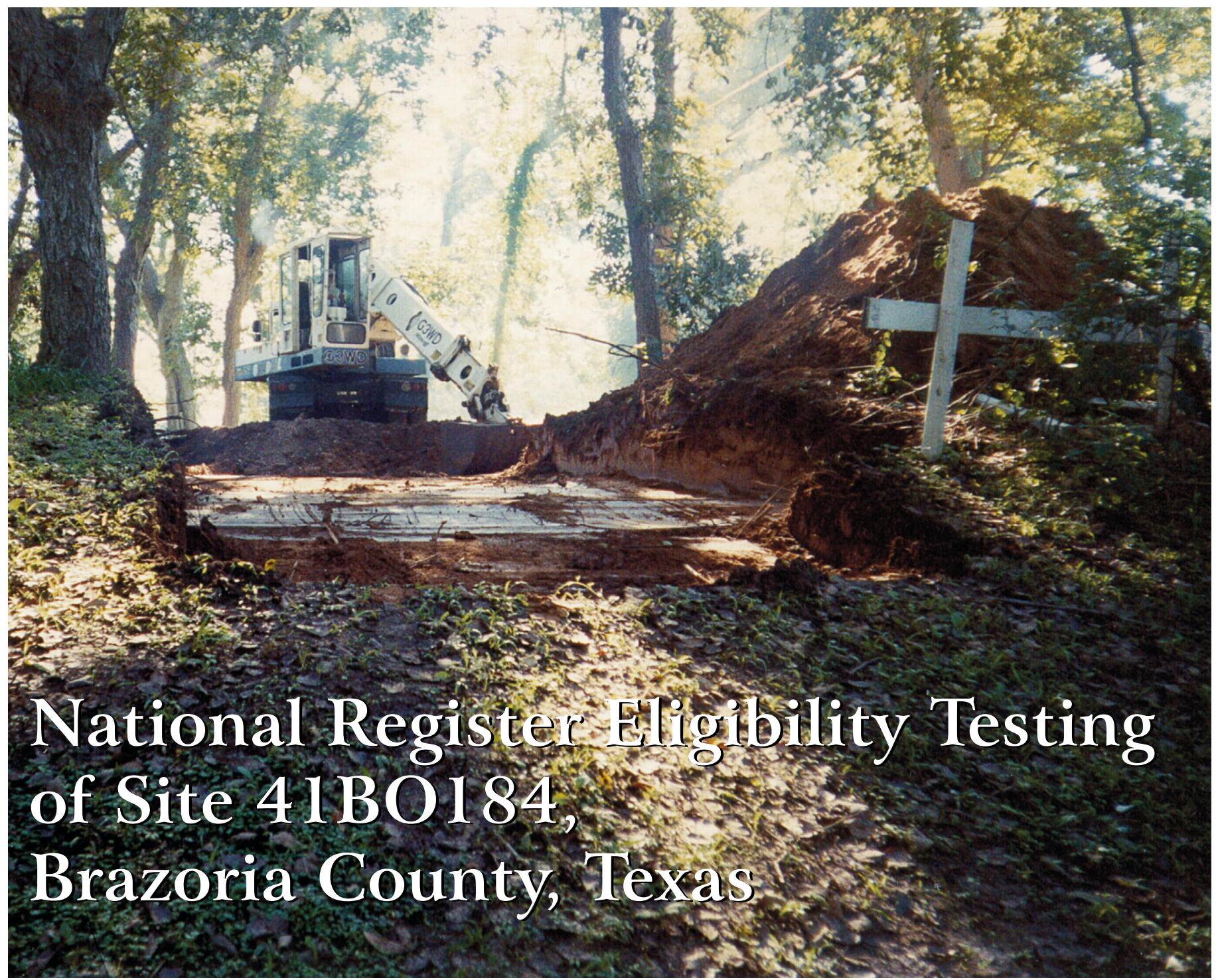

\section{by \\ Richard B. Mahoney and Steve A. Tomka}

Work Authorization No. 57307 SA002

Contract No. 573 XX SA002

CSJ: 0179-01-028

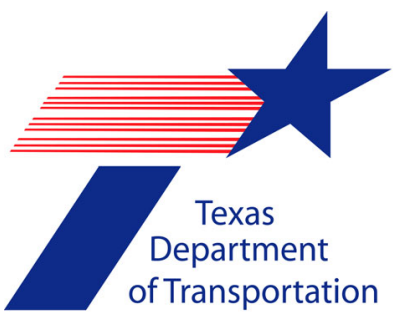

Environmental Affairs Division

Texas Department of Transportation

Archeological Studies Program, Report No. 63

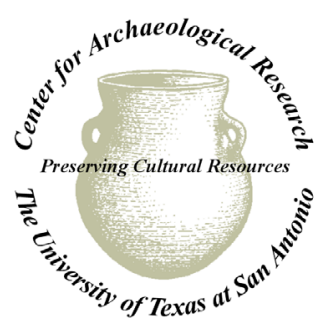

Center for Archaeological Research The University of Texas at San Antonio Archaeological Survey Report, No. 349 


\title{
National Register Eligibility Testing of Site 41BO184, Brazoria County, Texas
}

\author{
by \\ Richard B. Mahoney and Steve A. Tomka
}

Texas Antiquities Committee Permit No. 3210

Steve A. Tomka

Principal Investigator

\author{
Work Authorization No. 57307 SA002 \\ Contract No. 573 XX SA002 \\ CSJ: 0179-01-028
}

Prepared for:

Environmental Affairs Division

Texas Department of Transportation

Archeological Studies Program, Report No. 63

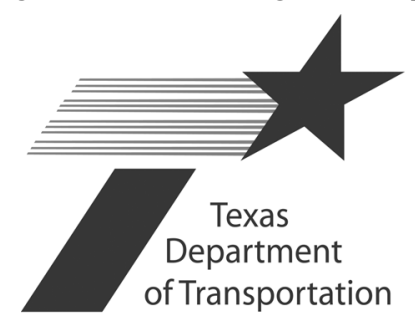

Prepared by:

Center for Archaeological Research The University of Texas at San Antonio Archaeological Survey Report, No. 349

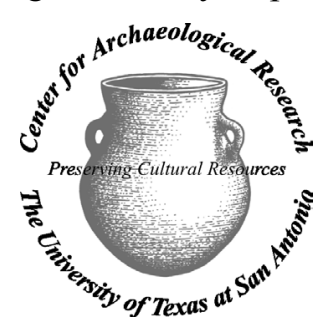




\title{
National Register Eligibility Testing of Site 41BO184, Brazoria County, Texas
}

\author{
Copyright ${ }^{{ }^{\circ}} 2004$ \\ Texas Department of Transportation (TxDOT) and Center for Archaeological Research, \\ The University of Texas at San Antonio (CAR-UTSA)
}

\begin{abstract}
All rights reserved
TxDOT and CAR-UTSA jointly own all rights, title, and interest in and to all data and other information developed for this project under Contract 573XXSA002. Brief passages from this publication may be reproduced without permission provided that credit is given to TxDOT and CAR-UTSA. Permission to reprint an entire chapter, section, figures or tables must be obtained in advance from the Supervisor of the Archeological Studies Program, Environmental Affairs Division, Texas Department of Transportation, 125 East 11th Street, Austin, 78701. Copies of this publication have been deposited with the Texas State Library in compliance with the State Depository requirements.
\end{abstract}

Printed by Kwik Kopy Printing on Main, San Antonio

2004

jointly published by

Texas Department of Transportation

Environmental Affairs Division

Archeological Studies Program

Owen Lindauer, Ph.D., Supervisor

Archeological Studies Program, Report No. 63

A. McGraw, Series Editor

and

Center for Archaeological Research

The University of Texas at San Antonio

Archaeological Survey Report, No. 349

Printed on acid-free, $60 \mathrm{lb}$. paper

ISBN: 1-930788-33-9 


\section{Abstract:}

Site 41BO184 is located within the right-of-way for the proposed expansion of State Highway 35 at the Oyster Creek crossing in southern Brazoria County. It was originally recorded as a multicomponent site in 1994 and was the subject of three distinct and limited archeological investigations by Texas Department of Transportation (TxDOT) staff. In 2003, TxDOT contracted with the Center for Archaeological Research (CAR) of The University of Texas at San Antonio to test the National Register of Historic Places and State Archeological Landmark eligibility of the site. Systematic mechanical auger borings, ten hand-excavated 1-x-1-meter test units, and Gradall scrapings helped identify a very sparse Late Prehistoric, possibly Rockport, component at the site. Although it is possible that at least some of the prehistoric artifacts come from the shell-paved driveway that cross-cut the site, it is also possible that some of the prehistoric artifacts represent in situ finds. The historic component, rich in temporally diagnostic ceramic fragments, dates to the mid-nineteenth century. The lack of intact features, the small size of the artifact assemblage, and the reduced size of the available materials, severely limits the research potential of the site. Therefore, it is recommended that site 41BO184 is not eligible for listing on the National Register of Historic Places nor does it warrant designation as a State Archeological Landmark. 


\section{Table of Contents:}

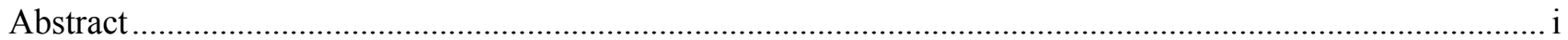

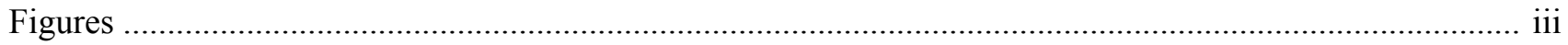

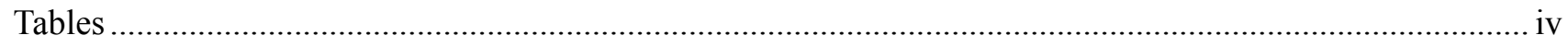

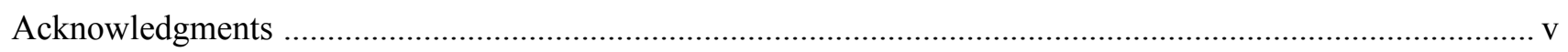

Chapter 1: Introduction

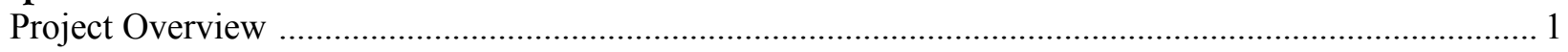

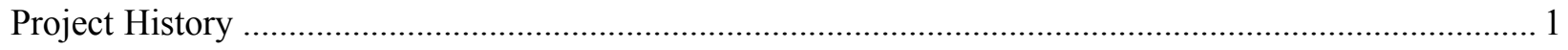

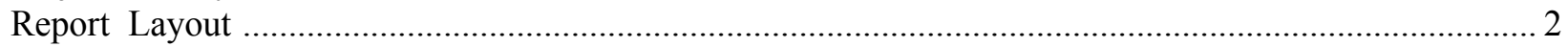

Chapter 2: Archeological Background

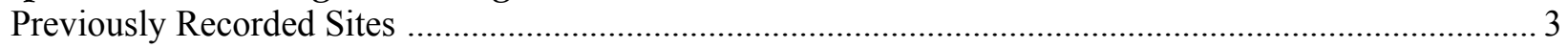

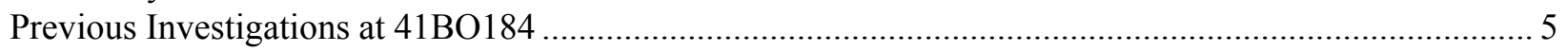

Chapter 3: Research Perspective

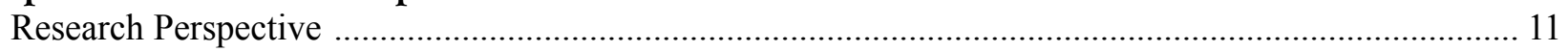

Chapter 4: Methodology

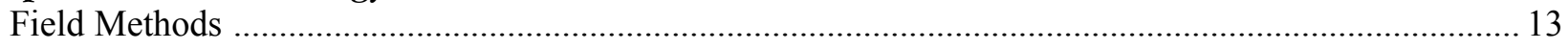

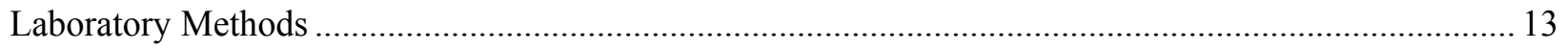

Chapter 5: Results

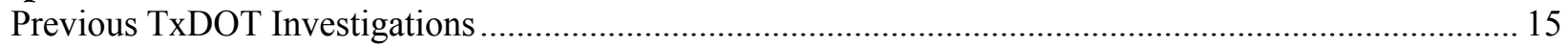

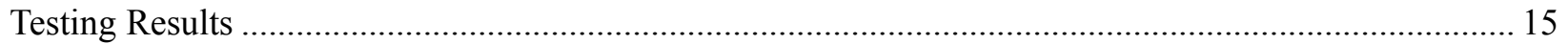

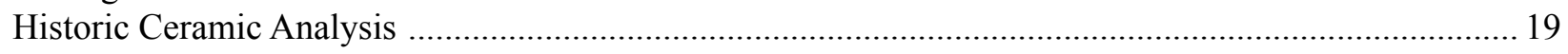

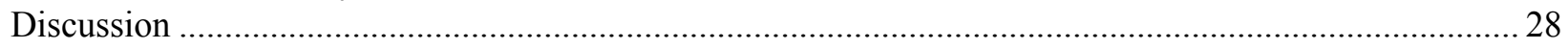

Chapter 6: Summary

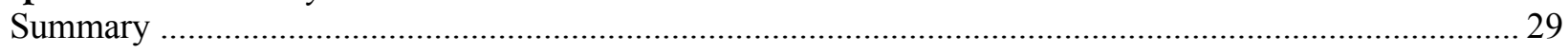

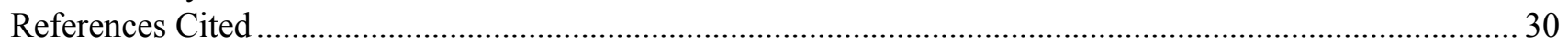

Appendix A: Historic Context Report, SH 35, Brazoria County, Texas

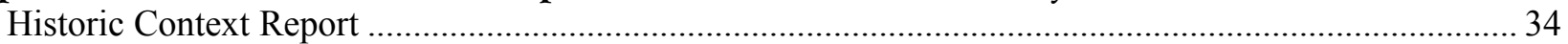




\section{Figures:}

Figure 1-1. Location of State Highway 35 Corridor Improvements Project in Brazoria County. .............................2

Figure 2-1. Number of recorded sites and population density of coastal counties. ................................................ 3

Figure 2-2. Relationship of selected historic sites to 41BO184 and SH 35 ................................................5

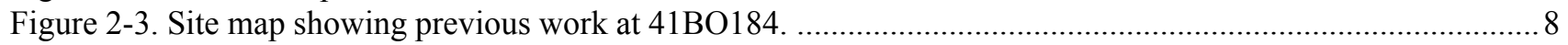

Figure 4-1. Site map with locations of Gradall scrapes and test units. .......................................................... 14

Figure 5-1. Rockport ceramic sherd recovered during the TxDOT 2002 investigations....................................... 16

Figure 5-2. Site map with locations of positive metal detector signals and test units. .......................................... 17

Figure 5-3. Photograph of completed Test Unit 7. Note oyster shell in profile. .................................................... 19

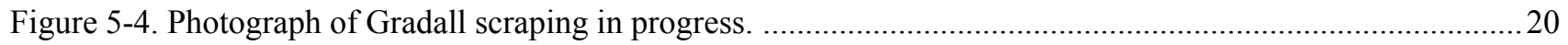

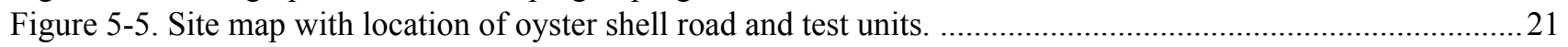

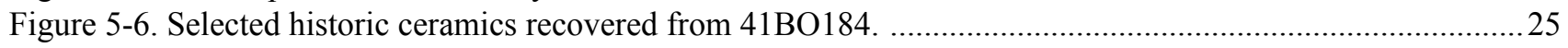

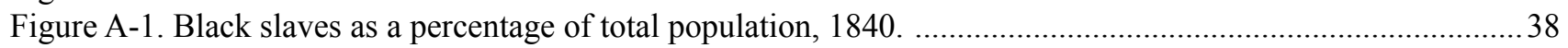

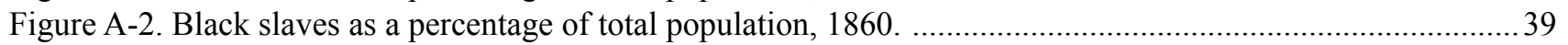

Figure A-3. Cotton gin on the Sweeny Plantation, Brazoria County, Texas, ca. 1870 ........................................ 41

Figure A-4. Waldeck sugar mill at Waldeck Plantation, Brazoria County, Texas. ................................................. 43

Figure A-5. Chenango Sugar Mill, Brazoria County, Texas. .............................................................................. 43

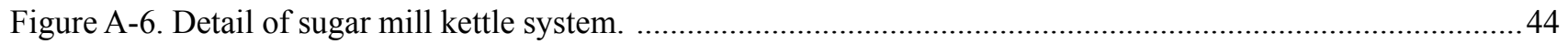

Figure A-7. 1914 plat map showing the location of Willow Glen Plantation. .........................................................4 48

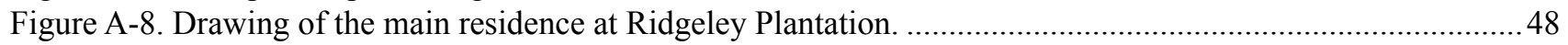

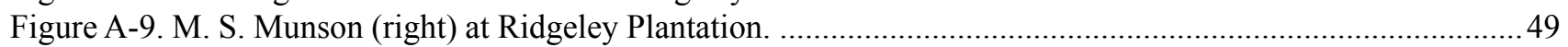

Figure A-10. Plat map showing Abner Jackson's plantation with sugar house, residence and outbuilding. .............50

Figure A-11. Map showing a public road adjacent to a ginhouse, residence, and slave quarters. ..........................55

Figure A-12. Drawing showing the Josiah Bell plantation, Brazoria County, circa 1830 ....................................53

Figure A-13. Abner Jackson's plantation home at Lake Jackson, Brazoria County. ...............................................53

Figure A-14. Slave cabin at Ridgeley Plantation, Brazoria County. ................................................................5

Figure A-15. Typical sugar plantation layout showing location of slave quarters. ...........................................5

Figure A-16. Slave community at Bernardo Plantation, Brazoria County..........................................................56

Figure A-17. Postbellum settlement patterns indicative of the sharecropping system. ........................................57

Figure A-18. Oil, gas, and sulfur deposits in Brazoria County, circa 1940 .........................................................5 


\section{Tables:}

Table 2-1. Number of Recorded Sites, Area, and Population of Coastal Counties ................................................

Table 2-2. Previously Recorded Historic Sites in Brazoria County .....................................................................5

Table 2-3. Horizontal Distribution of Artifacts Recovered During Auger Boring ................................................. 9

Table 2-4. Vertical Distribution of Artifacts Recovered During Auger Boring ................................................ 10

Table 2-5. Seriation of Ceramics Recovered During Auger Boring ................................................................... 10

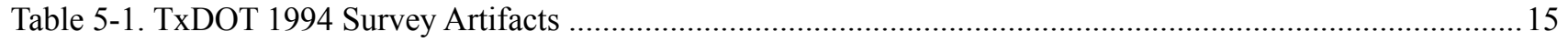

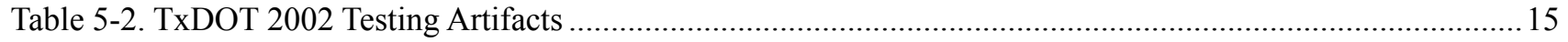

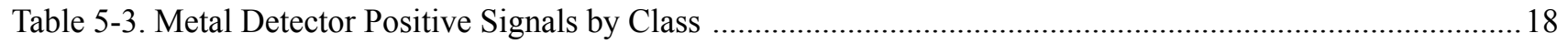

Table 5-4. Vertical Distribution of Artifacts Recovered During Testing ............................................................... 18

Table 5-5. Horizontal Distribution of Artifacts Recovered During Testing ....................................................... 18

Table 5-6. Classification of Historic Ceramics Recovered from 41BO184 ......................................................22

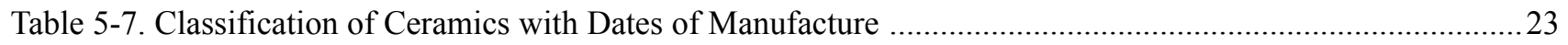

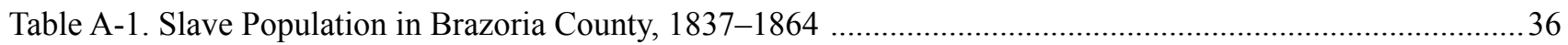

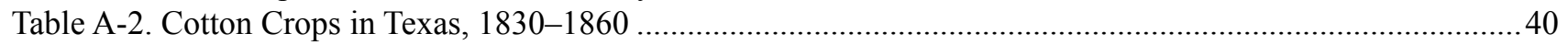

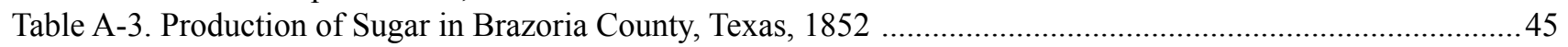

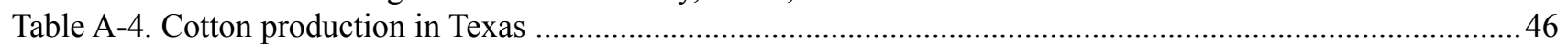




\section{Acknowledgments:}

The test excavations carried out at $41 \mathrm{BO} 184$ were successful in defining site eligibility due in large part to the cooperative efforts of numerous TxDOT and CAR staff members. James Abbott, Allen Bettis, Owen Lindauer, and Lain Ellis of the Environmental Affairs Division of TxDOT provided valuable advice and opinions during the development of a testing strategy at the site. Allen Bettis shared freely of his knowledge of the site and helped identify previously excavated areas. We also appreciate the logistical help of Mr. Mike Cristley P.E. of TxDOT's Brazoria Area Office. The mechanical auger was provided to CAR by the Berry Company of Houston and was operated by the project archeologist. The Gradall and operator were furnished by Reliant Sand and Gravel of Rosharon, Texas. We appreciate their cooperation and assistance. The hard working field crew consisted Rachael Davies, David Hafernik, and Stacy Wagner, who were directed by Project Archeologist Richard Mahoney. The laboratory processing, cataloging and quality checks were completed by Cindy Muñoz and Rebecca Galdeano under the supervision of Marybeth S. F. Tomka, CAR Laboratory Coordinator. Dr. Steve A. Tomka served as Principal Investigator and did the internal review of the manuscript. We also would like to acknowledge the assistance of Justin Edgington and HHM, Inc. in Houston, for providing the historic context for the project area and Dana Anthony of Anthony and Brown Consulting for reviewing the draft manuscript. Richard Young and Bruce Moses, CAR draftsmen, collaborated on the illustrations present in the text and Johanna Hunziker, CAR editor, hammered this manuscript in shape. We extend our heartfelt appreciation to each and every one of these hard working individuals. 



\section{Chapter 1: Introduction}

The Center for Archaeological Research (CAR) of The University of Texas at San Antonio was contracted by the Texas Department of Transportation (TxDOT; Work Authorization No. 57307SA002 to Contract No. 573XXSA002), Environmental Affairs Division, Austin, Texas, to conduct test excavations at a previously recorded archeological site in Brazoria County. The purpose of the current investigation was to assess, via manual and mechanical excavations, the National Register of Historic Places (NRHP) eligibility and State Archeological Landmark (SAL) status of site 41BO184.

The site is located within the proposed right-of-way (ROW) of State Highway 35 (SH 35) at the Oyster Creek crossing (TxDOT CSJ: 0179-01-028) in southern Brazoria County. Site 41BO184 will be impacted by the proposed expansion of SH 35. Subsurface disturbance as a result of the proposed development will impact an area of approximately 1,250 $\mathrm{m}^{2}$ of 41BO184 within the current and expanded ROW. The archeological investigations were conducted under Texas Antiquities Permit No. 3210, with Steve A. Tomka, CAR Director, serving as Principal Investigator.

\section{Project Overview}

The eligibility testing, the subject of this report, is part of the SH 35 Corridor Improvements Project, a highway improvement undertaking covering approximately 30 miles between the cities of Van Vleck in Matagorda County and Angleton in Brazoria County (Figure 1-1). Site 41BO184 is located in Bailey's Prairie, a small community just west of Angleton. The existing SH 35 is a two-lane, undivided rural facility with shoulders and open ditches. The existing ROW ranges from 100-120 feet in width. The proposed corridor improvements will result in the construction of a four-lane, divided facility with a grass median.

The project is located in the southern portion of Brazoria County and is contained on the Angleton (2995-123) USGS 7.5 ' quadrangle map (1963, photo revised 1974). The width of the area of potential effect (APE) is depicted on TxDOT construction plans, with the proposed ROW expansion measuring roughly $13 \mathrm{~m}$ (42 feet) at this location.

Due to variable letting dates and to facilitate cultural resources antiquities clearance, the project area was divided into three sections. Site 41BO184 is contained within Section
2 of the Angleton to Old Ocean segment of the overall project. Section 2 extends between STA $20+00$ to STA $205+00$ (SH 288 to SH 251). It has a total length of roughly $5.64 \mathrm{~km}$ (3.5 miles).

\section{Project History}

Archeological survey for the development of SH 35 in this portion of Brazoria County has spanned nearly a decade prior to the production of this report. In 1994, then TxDOT Staff Archeologist Christine Ward conducted the first survey of the proposed SH 35 development. She identified two previously unrecorded archeological sites, 41BO184 and 41BO185. At that time, 41BO184 was interpreted as a prehistoric site of unknown temporal affiliation, and 41BO185 was interpreted as a historic site, likely associated with mid- to late-nineteenth-century occupations.

During 2001 and 2002, TxDOT Staff Archeologist Allen Bettis returned to site 41BO184 for further investigation. In addition to encountering a few prehistoric artifacts, Bettis identified a discrete historic component buried between 20 $40 \mathrm{~cm}$ below surface (Allen Bettis, personal communication 2003). Preliminary analysis of the recovered historic artifacts suggested antebellum affiliation.

In 2003, as part of the SH 35 Corridor Improvements Project, CAR continued site definition at 41BO184 with intensive mechanical auger excavations (Mahoney 2003). Thirty-six auger borings were dug to $120 \mathrm{~cm}$ below surface (bs) on a 5 -m grid across the previously delimited site bounds. A single lithic flake was recovered in a disturbed and/or redeposited context, and a discrete prehistoric component could not be defined. However, several additional historic artifacts and, most importantly, temporally diagnostic ceramics were recovered, suggestive of a promising historic component.

Concomitant with CAR's field survey, HHM, Inc. of Houston conducted archival research to determine the location and nature of potential antebellum plantations within the APE. Through their research, HHM located three plantations, portions of which will be impacted by the proposed ROW expansion. As expressed within the APE, the following portions of the plantations will be impacted along SH 35: Variety Grove Plantation ( $880 \mathrm{~m}$ long and 34 $\mathrm{m}$ wide; 3.0 ha [7.4 ac]); Bailey Plantation (900 $\mathrm{m}$ long and $40 \mathrm{~m}$ wide; 3.6 ha [8.9 ac]); and Willow Glen Plantation 
( $870 \mathrm{~m}$ long and $54 \mathrm{~m}$ wide; $4.7 \mathrm{ha}[11.6 \mathrm{ac}]$ ). The fact that site 41BO184 is located within the Variety Grove Plantation further highlighted the potential importance of its historic component. To provide a broad historic context to this report, the HHM report, written by J. B. Edgington, is reproduced in its entirety as Appendix A of this report.

\section{Report Layout}

This report is comprised of six chapters and one appendix. Following this introductory chapter, Chapter 2 reviews the archeological background for the area, including previously recorded archeological sites in Brazoria County and previous archeological investigations at 41BO184. Chapter 3 presents the research perspective that guided the eligibility testing fieldwork. Chapter 4 discusses the methodology employed for the testing, specifically the field and laboratory methods. Discussion of the field methods includes aspects of the metal detector survey, manual test excavations, and Gradall scraping. Chapter 5, Results, details the outcome of the fieldwork and laboratory processing. Chapter 6 summarizes the current project and makes recommendations regarding the site's eligibility for listing on the NRHP and for designation as a SAL. The single appendix contains the Historic Context report by HHM, Inc.

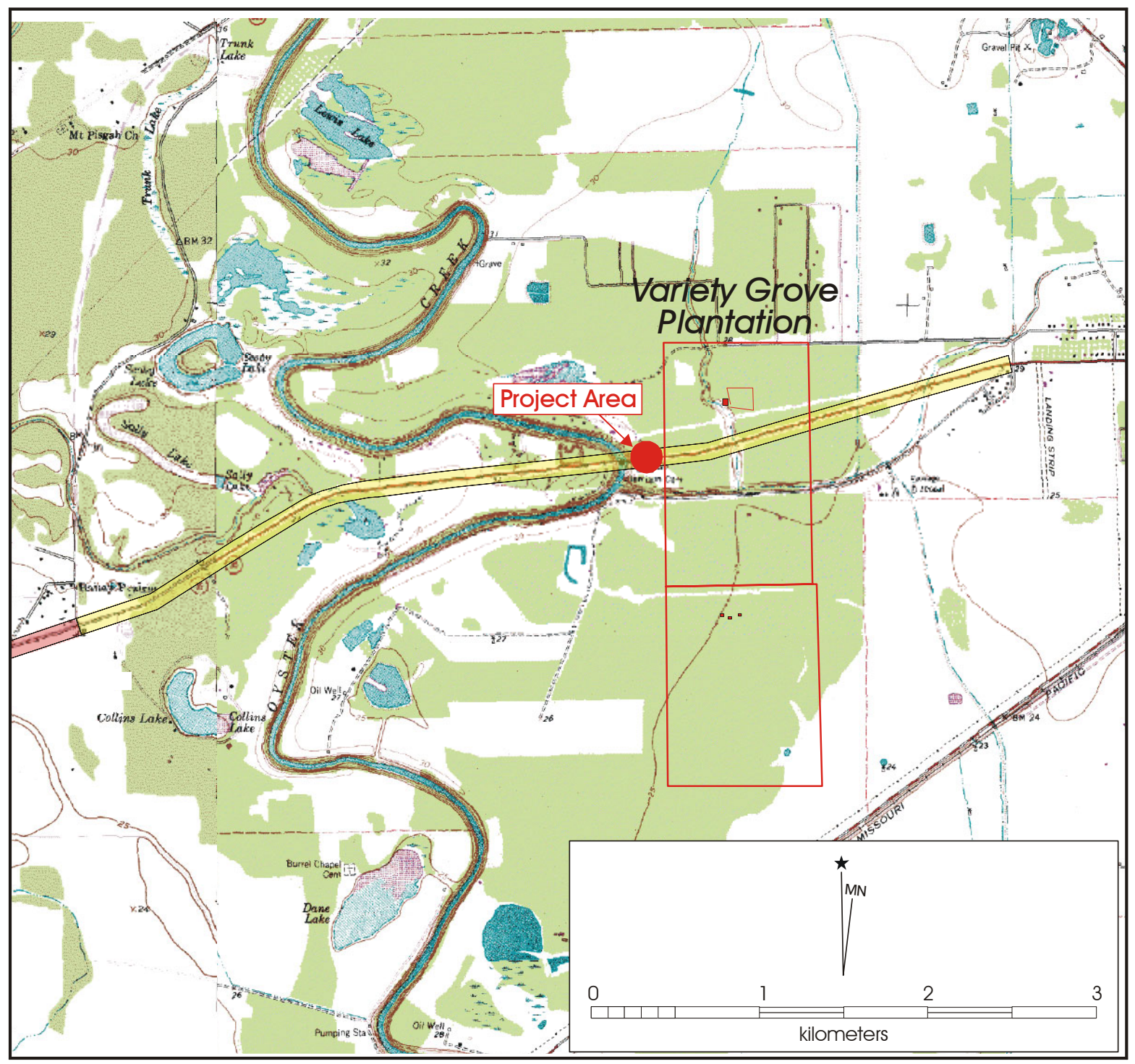

Figure 1-1. Location of State Highway 35 Brazoria County Corridor Improvements Project. 


\section{Chapter 2: Archeological Background}

This chapter briefly discusses the archeological background of the project area. Following an introduction to the sum of known archeological sites in Brazoria County, the discussion turns to the historic period sites. This focus is deemed relevant, as the tested component at 41BO184 was historic.

\section{Previously Recorded Sites}

To summarize the range of previously recorded sites in Brazoria County, the Texas Archeological Sites Atlas (Texas Historical Commission [THC] 2003a) was consulted in August 2003. At that time, a total of 217 archeological sites had been recorded in the county. Of this total, only 159 site forms were complete. The remainder of the sites contained either "corrupted" data $(\mathrm{n}=18)$ or Key Site Cards $(\mathrm{n}=34)$ with limited or incomplete data; six sites contained no data whatsoever.

To date, few investigations have been conducted in Brazoria County, resulting in the documentation of only 217 sites in the county, or only one recorded site per every 6.5 square miles. In comparison with surrounding counties, such as
Harris County with 974 recorded sites or one site per every 1.8 square miles, archeological sites in Brazoria County are clearly under-represented.

A probable explanation for the relative paucity of recorded archeological sites is the comparatively lower modern population density and associated construction and development of the landscape. Specifically, while Brazoria County is roughly 80 percent of the area of Harris County, the current population of Brazoria County is only six percent of that of Harris County. Figure 2-1 depicts that, with few exceptions, counties with high modern population densities also have a higher number of recorded sites. Thus, with few exceptions (i.e., Chambers and Jackson counties), the current population of a given county along the Texas Gulf Coast is a rough indicator of the number of recorded archeological sites within the county (Table 2-1). Nonetheless, it is recognized that the factors that explain the number of archeological sites within a region consist of a complex mix of factors including population density, land use, public and private development, and the influence of local and county archeological organizations.

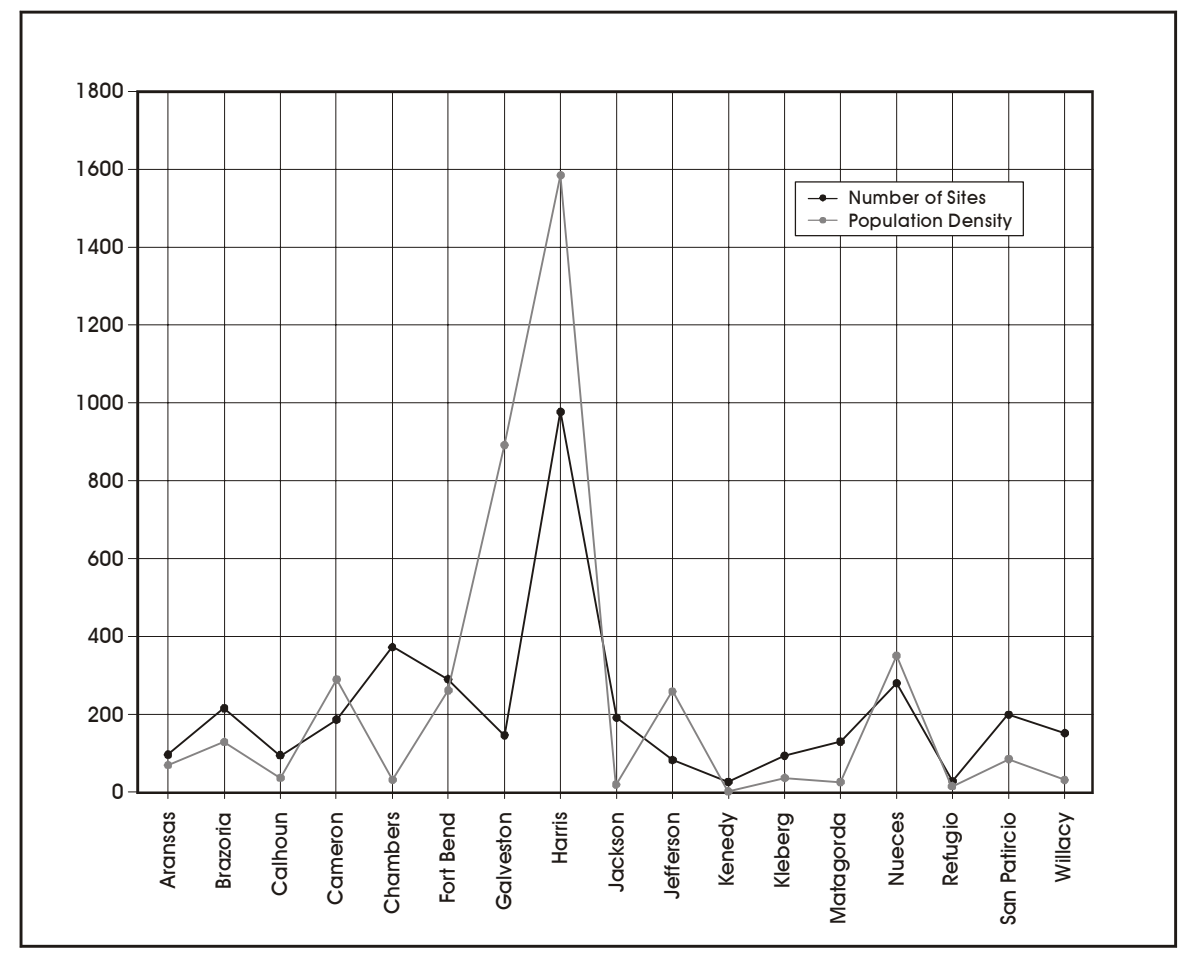

Figure 2-1. Number of recorded sites and population density of coastal counties. 
Table 2-1. Number of Recorded Sites, Area, and Population of Coastal Counties

\begin{tabular}{|l|c|c|c|}
\hline \multicolumn{1}{|c|}{ County } & \# of Sites & Square Miles & 1990 Population \\
\hline Aransas & 92 & 276 & 17892 \\
\hline Brazoria & 217 & 1407 & 182244 \\
\hline Calhoun & 94 & 540 & 19053 \\
\hline Cameron & 185 & 905 & 260120 \\
\hline Chambers & 372 & 616 & 19100 \\
\hline Fort Bend & 291 & 869 & 225421 \\
\hline Galveston & 147 & 225 & 200000 \\
\hline Harris & 974 & 1778 & 2818199 \\
\hline Jackson & 188 & 844 & 13039 \\
\hline Jefferson & 80 & 937 & 239397 \\
\hline Kenedy & 22 & 1389 & 460 \\
\hline Kleberg & 94 & 853 & 30274 \\
\hline Matagorda & 128 & 1612 & 36928 \\
\hline Nueces & 284 & 847 & 296527 \\
\hline Refugio & 23 & 771 & 7967 \\
\hline San Patricio & 201 & 693 & 59288 \\
\hline Willacy & 150 & 589 & 17705 \\
\hline
\end{tabular}

\section{Historic Sites}

Of the 217 previously recorded sites in Brazoria County, 43 contain primarily or solely historic components. Ages of recorded sites span the Mexican Republic period through the twentieth century. The earliest recorded site is the James Briton Bailey Plantation (41BO190) established in 1818, and the latest recorded site is the shipwreck of the George Vancouver (41BO183), with a build date of 1942.

Numerous historic site types comprise the assemblage in Brazoria County (Table 2-2). Antebellum plantations constitute the greatest number, with a total of ten $(23 \%)$ recorded as archeological sites. Nine (21\%) sites consist of artifact scatters or deposits not associated with structural or foundation remains. Historic shipwrecks account for six (14\%) sites. The remaining 42 percent of recorded historic sites includes cemeteries $(\mathrm{n}=5)$, structures $(\mathrm{n}=5)$, military sites $(\mathrm{n}=3)$, industrial sites $(\mathrm{n}=2)$, communities $(\mathrm{n}=2)$, and one corridor (the Brazos Canal).

The SH 35 project corridor passes through the area of Stephen F. Austin's "Old 300" land grant settlement. Two historic properties listed on the THC's Historic Sites Atlas (THC 2003b), the Munson Cemetery and the Bailey Plantation (41BO190), are indicated near the Section 1 (STA $205+00$ to STA 505+00) ROW, and the corridor also crosses or passes near portions of the Sweeny Plantation (41BO109), Ridgeley Plantation, Bynum Plantation, Josiah Bell Plantation, and the Ward or Old Jones Plantation. Figure 2-2 shows the relationship of some of these historic sites to 41BO184. The THC map files also indicate that the historic Jamison Cemetery is located south of 41BO184 across SH 35, and the historic African-American Morris Family Cemetery is located within the overall project corridor along the Ocean Bypass route (note that TxDOT is coordinating this portion of the proposed project with THC separately from these testing investigations). The Munson Cemetery is a Texas Historic Landmark originally set aside by Mordello S. Munson, son of Henry W. Munson, at Ridgeley Plantation on Bailey's Prairie. The Bailey Plantation was established in 1818 by Mr. James B. Bailey, the namesake of the prairie. Section 3a (STA 505+00 to STA 605+00) of the project area has four known historic properties in its vicinity but outside of the immediate ROW. Bell's Landing was founded in 1823 as a Brazos River landing for the Josiah $\mathrm{H}$. Bell plantation. It is located on the right-descending bank of the Brazos River south of the ROW. Carry Nation's Hotel was established in 1880 on the left-descending bank of the river in East Columbia. The Dance Brothers Gun Factory and Shop (41BO174), in East Columbia, were established in the late 1850 s to serve the Confederacy. Only foundations remain of the buildings that formerly stood on the leftdescending bank of the Brazos River. Finally, there are two other known historic sites immediately west of the western 
Table 2-2. Previously Recorded Historic Sites in Brazoria County

\begin{tabular}{|c|c|c|c|c|c|}
\hline $\begin{array}{r}\text { Site } \\
41 \mathrm{BO}\end{array}$ & Site Name & Site Age & Site Type & Owner / Founder & $\begin{array}{c}\text { Date } \\
\text { Founded }\end{array}$ \\
\hline 77 & McCroskey Log Cabin & Mexican Republic & Sugar Plantation & John McCroskey & 1824 \\
\hline 80 & Ellerslie Plantation & Mexican Republic & Sugar Plantation & John Greenville McNeel & 1824 \\
\hline 109 & Sweeny Plantation & Mexican Republic & Sugar Plantation & John Sweeny, Sr. & 1832 \\
\hline 110 & - & Twentieth Century & Artifact Scatter & $?$ & $?$ \\
\hline 116 & - & Civil War / WWII & Military & Confederate States of America & 1861 \\
\hline 122 & Velasco Cemetery & Late 19th / Early 20th Century & Cemetery & Brazos Investment Company & 1891 \\
\hline 123 & Quintana Cemetery & Late 19th / Early 20th Century & Cemetery & Henry Seaburn & 1895 \\
\hline 124 & Hudgins Cemetery & Late 19th / Early 20th Century & Cemetery & William P. Hudgins & 1909 \\
\hline 125 & Velasco & Mexican Republic & Village & Asa Mitchell & 1824 \\
\hline 127 & - & Antebellum & House Foundation & $?$ & $?$ \\
\hline 128 & - & Antebellum & House Foundation & $?$ & $?$ \\
\hline 133 & Patton Plantation (Varner-Hogg) & Mexican Republic / Texas Republic & Sugar Plantation & Columbus R. Patton & 1834 \\
\hline 136 & Durazno Plantation & Mexican Republic / Texas Republic & Sugar Plantation & William Joel Bryan & 1840 \\
\hline 147 & - & Late 19th / Early 20th Century & House Foundation & $?$ & $?$ \\
\hline 151 & Mud Island Fort & Civil War & Military & Confederate States of America & 1861 \\
\hline 157 & S.S. Acadia & Civil War & Shipwreck & Captain Thomas Leach & 1864 \\
\hline 164 & Fannin - Mims Plantation & Mexican Republic / Texas Republic & Cotton / Sugar Plantation & James Fannin, Jr., \& Joseph Mims & 1834 \\
\hline 170 & Ducroz Cemetery & Twentieth Century & Cemetery & Joseph Lawrence Ducroz & 1907 \\
\hline 171 & Gen. C.B. Comstock Shipwreck & Late 19th / Early 20th Century & Shipwreck & United States Army Corps of Engineers & 1895 \\
\hline 172 & Lake Jackson Plantation & Antebellum & Sugar Plantation & Abner Jackson & 1844 \\
\hline 173 & TPC Shipwreck & Twentieth Century & Shipwreck & $?$ & $?$ \\
\hline 174 & Dance Gun Shop & Civil War & Industrial & Dance Brothers (J.H., George, \& David) & 1850 \\
\hline 175 & Fort Terrell & Civil War & Military & $?$ & $?$ \\
\hline 177 & - & Twentieth Century & Artifact Scatter & $?$ & $?$ \\
\hline 178 & - & Twentieth Century & Artifact Scatter & $?$ & $?$ \\
\hline 183 & George Vancouver Shipwreck & Twentieth Century & Shipwreck & Kaiser Company & 1942 \\
\hline 184 & William Jamison Farm & Antebellum & Artifact Scatter & William Jamison & 1850 \\
\hline 185 & - & Civil War & Industrial & $?$ & $?$ \\
\hline 186 & McKinstry House & Mexican Republic & Town Lot & George B. McKinstry & 1830 \\
\hline 187 & Orozimbo Plantation & Mexican Republic & Cotton Plantation & James Aeneas Phelps & 1824 \\
\hline 188 & Waldneck Plantation & Mexican Republic / Texas Republic & Sugar Plantation & Count Ludwig von Boos-Waldeck & 1842 \\
\hline 189 & Lochridge Village & Twentieth Century & Community & Blackburn Lochridge & 1913 \\
\hline 190 & Brit Bailey House / Grave & Mexican Republic & House / Grave & James Briton Bailey & 1818 \\
\hline 196 & Brazos Canal & Texas Republic & Corridor & Brazos Canal Company & 1847 \\
\hline 199 & - & Twentieth Century & Shipwreck & $?$ & $?$ \\
\hline 200 & - & Twentieth Century & Shipwreck & $?$ & $?$ \\
\hline 202 & Pioneer Cemetery & Late 19th / Early 20th Century & Cemetery & $?$ & 1888 \\
\hline 203 & Bingham House & Twentieth Century & House & Bingham Family & 1904 \\
\hline 204 & Providence Plantation & Antebellum & Artifact Scatter & Francis Bingham & 1827 \\
\hline 212 & - & Late 19th / Early 20th Century & Artifact Scatter & $?$ & $?$ \\
\hline 213 & Darrington State Prison Farm & Twentieth Century & Trash Dump & State of Texas & 1917 \\
\hline 214 & Palmer General Store & Twentieth Century & Artifact Scatter & Morris Palmer & 1900 \\
\hline 216 & - & Late 19th / Early 20th Century & Artifact Scatter & $?$ & $?$ \\
\hline
\end{tabular}

\section{Previous Investigations at $41 \mathrm{BO} 184$ TxDOT Investigations}

portion of Section $3 a-41 B O 185$ and the site of the First Capitol of the Republic of Texas. Site $41 \mathrm{BO} 185$ is a possible Civil War-era campground located north of SH 35 and just east of West Columbia. The structure that actually became the First Capitol of the Republic of Texas in 1836 was built around 1833. This structure was destroyed in a 1900 storm and a replica was erected on the original site in 1976-77. The site is near downtown West Columbia.
A variety of surveys associated with the SH 35 corridor project proper have been conducted since 1993. A review of the Texas Archeological Sites Atlas for the survey area indicates two sites (41BO184 and 41BO185) within the corridor; 41BO185 was determined ineligible for nomination to the National Register of Historic Places on 5/22/2000 (Dismukes 2003). The other known site within the ROW, 41BO184, was originally defined as a multicomponent 


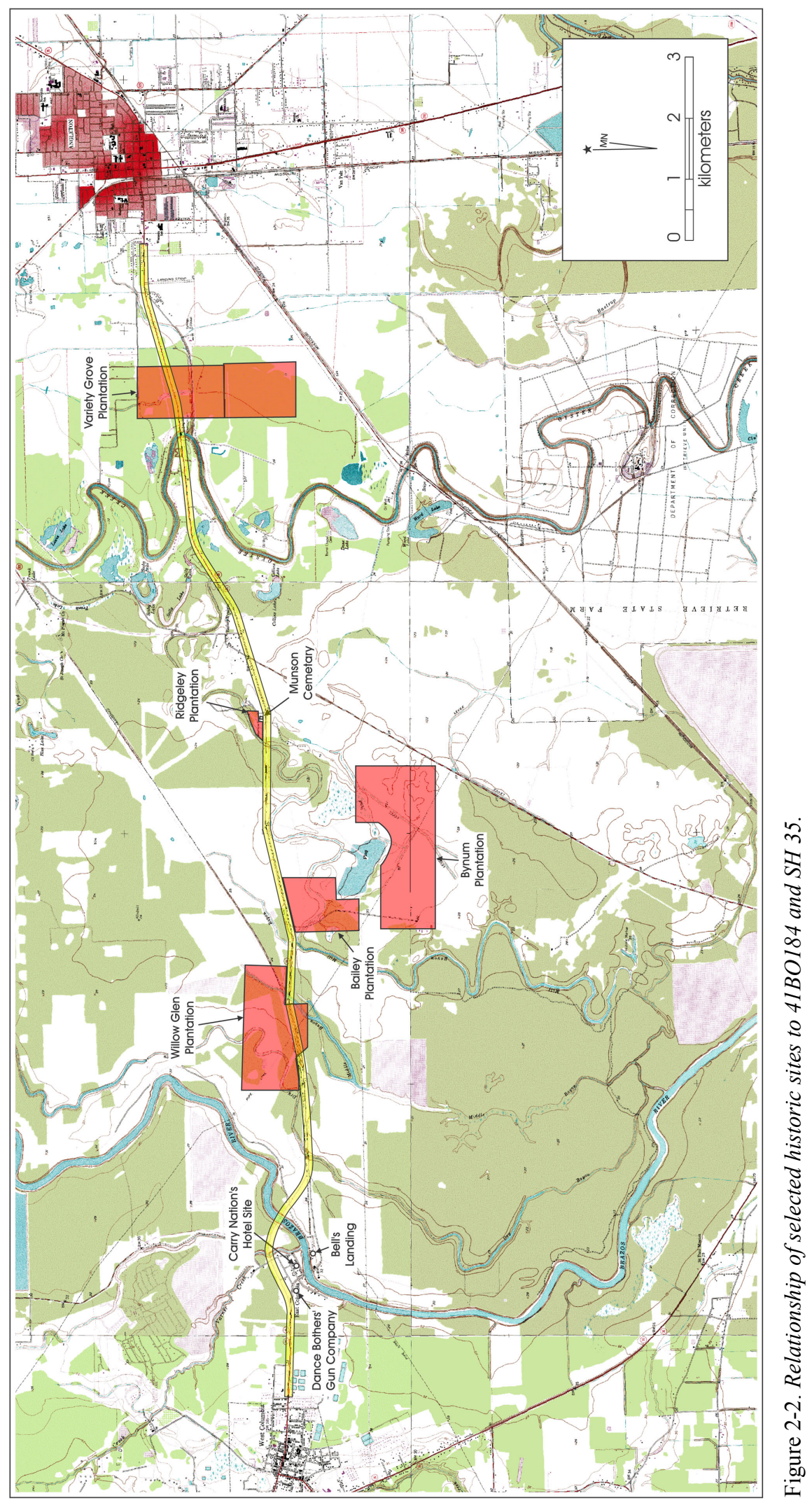


prehistoric open campsite and historic plantation site, located on the left-descending bank of Oyster Creek.

Ten shovel tests were excavated on site in 1994 at the time of the original survey conducted by Christine Ward. While materials were recovered in five of the ten shovel tests, unequivocally prehistoric materials (i.e., lithic debitage) were recovered in only two shovel tests (STs 4 and 8). Although the other three shovel tests did produce oyster shell, mussel shell and animal bone, the age of these materials was unclear particularly since a few historic artifacts (i.e., a wire nail and brick fragments) were also recovered in the shovel tests. In addition to these artifacts, a layer of mussel shell concentrated within a 20 -cm-thick zone buried between 40-60 cmbs was also identified during the original testing.

In 2001 and again in 2002, Allen Bettis of the Environmental Affairs Division of TxDOT made additional follow up visits to the site and excavated one additional shovel test the first year and two additional shovel tests and two shallow Gradall trenches in 2002. One of the shovel tests and one of the Gradall trenches were positive for cultural materials. While these tests produced a few prehistoric materials (i.e., debitage and a ceramic sherd), they also identified a discrete component of historic ceramic and faunal remains that may be associated with Steven F. Austin's “Old 300” colonist's plantation settlement. TxDOT Archeologist Al McGraw identified these as antebellum, possibly Republic of Texas, and Sergio Iruegas, formerly of the Texas Historical Commission, agreed with the identification based on the historic ceramics.

\section{CAR Investigations}

As part of the SH 35 Corridor Improvements Project, the systematic pedestrian survey carried out by CAR also included the Angleton to Old Ocean (Mahoney et al. 2003) segment of SH 35. During this phase of the project, site 41BO184, located on the banks of Oyster Creek, was subject to a preliminary survey (Mahoney 2003). The site assessment was performed to clarify various aspects of the site, including the types of sediments present, the degree of disturbance, and the density and distribution of cultural material. The assessment included the pedestrian survey and the excavation of shovel tests, shovel probes, backhoe scrapes, and mechanical auger borings.

\section{Pedestrian Survey}

The pedestrian survey consisted of a crew of two persons walking the entirety of the site at 15-m intervals. Allen Bettis,
TxDOT archeologist, joined the CAR crew during initial survey of the site. Mr. Bettis aided in relocation of the TxDOT Gradall trenches, which were nearly obscured by landowner maintenance activities and ground cover. Previously delimited site bounds were determined, as well as the extent of previous shovel test coverage. No structural or foundation features were observed during the survey. And, in fact, a single undecorated whiteware sherd, encountered at ground surface approximately $5 \mathrm{~m}$ west of the well, was the only indication that the location represented a historic site.

\section{Shovel Tests, Probes, and Backhoe Scrapes}

Prior to mechanical auger boring of the site, shovel tests, shovel probes, and backhoe scrapes were performed to investigate subsurface deposits. More specifically, the purpose of these preliminary excavations was twofold: (1) to determine whether the sediments would require water screening or were sufficiently coarse for standard dry screening; and (2) to investigate the horizontal extent of possible historic and/or modern road base material.

To accomplish the first goal, two shovel tests were manually dug to $80 \mathrm{cmbs}$ in the apparent highest point atop the existing ground surface, near the center of the site (Figure 2-3). Excavation to this depth extended below the depth of any of the cultural material from the previous TxDOT field efforts. All sediments were screened through 1/4-inch hardware cloth, and no cultural material was encountered. Sediments encountered during these shovel tests were consistent with coarse-grained overbank deposits that did not require labor-intensive water screening efforts.

To accomplish the second goal, 13 shovel probes and two backhoe scrapes were dug within the current ROW just north of SH 35 (Figure 2-3). None of the matrix from these shovel probes was screened and the probes were terminated once they encountered road metal consisting of a dense layer of oyster shell and concrete rubble. The top of this layer occurred between $10 \mathrm{~cm}$ and $20 \mathrm{~cm}$ below surface. Two backhoe scrapes were placed in the vicinity of the probes to further define the thickness of the impenetrable layer of oyster shell road metal, which varied from $10-30 \mathrm{~cm}$ in thickness and terminated at $20-40 \mathrm{cmbs}$. No archeologically significant deposits of cultural material or cultural features were encountered during these preliminary excavations.

\section{Mechanical Auger Excavations}

Following these preliminary field efforts, 36 auger borings were mechanically excavated within the combined current and expanded ROW corridor (Figure 2-3). A 5-m grid was 


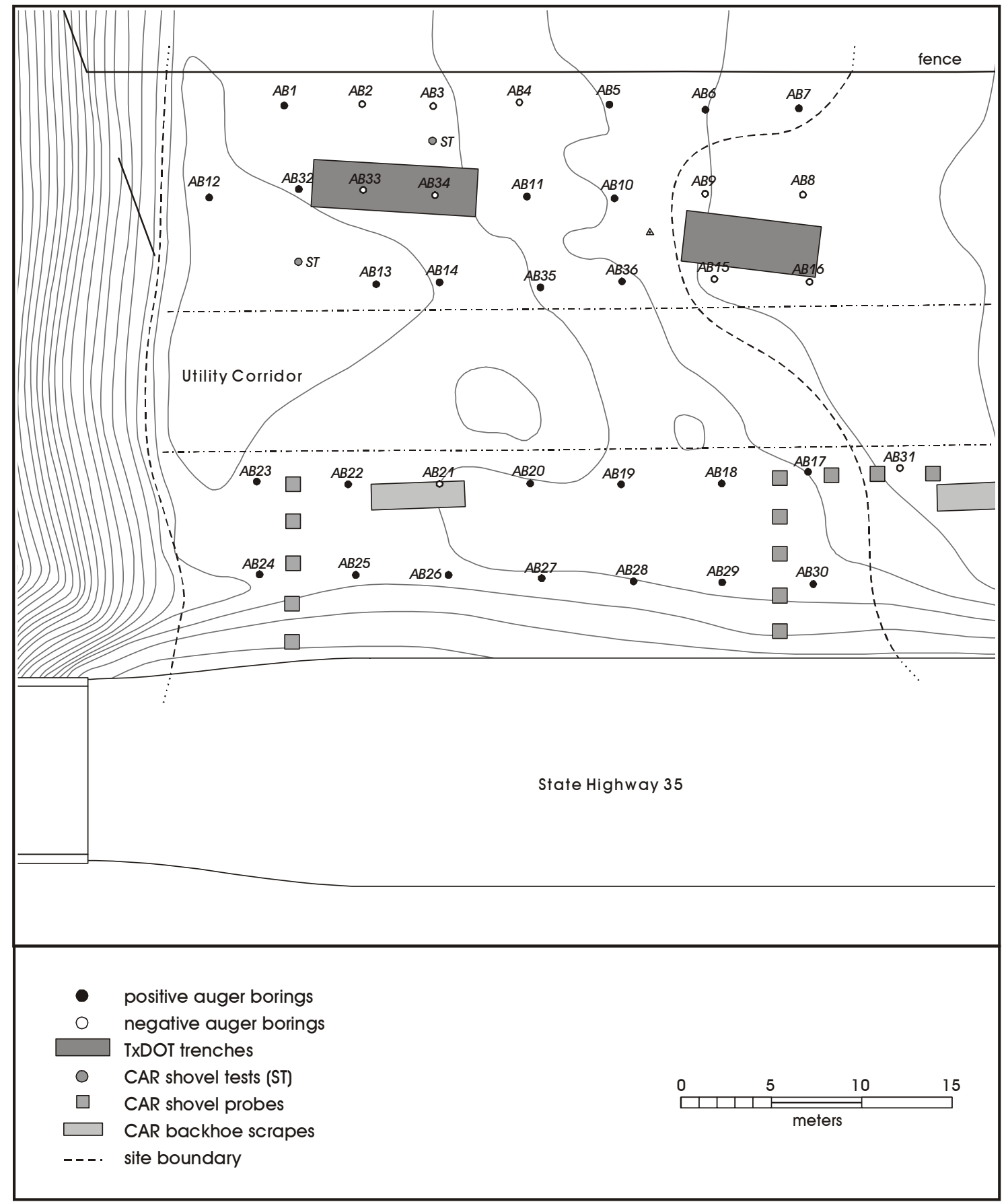

Figure 2-3. Site map showing previous work at 41 BO184. 
established over the site, with a single auger boring (AB) placed at each node along the grid. One exception to this method was the utility corridor that bisects the portion of the site within the ROW. Underground utilities were suspected along this portion of the site, and an eight-meter swath of the ROW lying directly beneath extant power lines remained untested due to the potential for underground lines.

Mechanical augering to $120 \mathrm{cmbs}$ was conducted using a Bobcat ${ }^{\circledR}$ MT50 equipped with a four-foot long and nineinch diameter auger bit. Each auger boring measured roughly $23 \mathrm{~cm}$ in diameter. The borings were excavated in three $40-\mathrm{cm}$ levels from ground surface to $120 \mathrm{cmbs}$. Cultural material recovered from each boring was maintained with the $40-\mathrm{cm}$ level with which it was associated, bagged accordingly, and recorded on a field sack log.
The mechanical excavation of the 36 auger borings across the site helped reveal the horizontal and vertical extent of the cultural material associated with 41BO184. As depicted in Figure 2-3, cultural material was present across the entire site area and dropped off east of the site boundary. Table 2-3 lists the number and types of artifacts recovered from each of the positive auger borings. Table 2-4 lists the number and types of artifacts recovered from each of the three 40$\mathrm{cm}$ levels excavated by auger. Of note in Table 2-4 is that only a single artifact was recovered below $40 \mathrm{cmbs}$.

The bulk of the diagnostic historic ceramics $(n=21 ; 56 \%)$ was recovered from the southern portion of the site: that portion of the site between the current SH 35 roadway and the power lines. A total of $16(44 \%)$ diagnostic historic ceramics was recovered north of the power lines. Based on

Table 2-3. Horizontal Distribution of Artifacts Recovered during Auger Boring

\begin{tabular}{|c|c|c|c|c|c|c|c|c|c|c|c|}
\hline $\begin{array}{l}\text { Auger } \\
\text { Boring }\end{array}$ & Bone & Brick & Ceramic & Concrete & Debitage & Glass & Gravel & Metal & Mortar & Plastic & Rubber \\
\hline 1 & - & 1 & - & - & 1 & - & - & - & - & - & - \\
\hline 5 & 30 & - & - & - & - & - & - & - & - & - & - \\
\hline 6 & 4 & - & - & - & - & - & - & - & - & - & - \\
\hline 7 & 1 & - & - & - & - & - & - & - & - & - & - \\
\hline 10 & - & 12 & - & - & - & - & - & - & - & - & - \\
\hline 11 & - & - & 1 & - & - & - & - & - & - & 2 & - \\
\hline 12 & 1 & - & - & - & - & - & - & - & - & - & - \\
\hline 13 & 3 & - & 1 & - & - & - & - & - & - & - & - \\
\hline 14 & - & - & 4 & - & - & 1 & - & 1 & - & - & - \\
\hline 17 & 2 & 17 & 3 & 5 & - & 1 & 1 & 4 & - & - & - \\
\hline 18 & 1 & - & 1 & 1 & - & - & - & - & 1 & 1 & - \\
\hline 19 & 3 & - & 4 & 3 & - & 3 & 11 & - & - & - & - \\
\hline 20 & 1 & - & 1 & 3 & - & - & 1 & 2 & - & - & - \\
\hline 22 & 1 & - & - & - & - & - & - & - & - & - & - \\
\hline 23 & 2 & - & 1 & - & - & 2 & - & 1 & - & - & - \\
\hline 24 & - & 9 & 4 & - & - & 9 & 1 & - & - & - & - \\
\hline 25 & - & - & 1 & 3 & - & 3 & 17 & - & - & - & - \\
\hline 26 & 1 & 11 & 3 & - & - & 3 & 4 & 2 & - & 1 & - \\
\hline 27 & - & 2 & 2 & - & - & 10 & 4 & 6 & - & 2 & - \\
\hline 28 & - & 1 & - & 2 & - & 10 & 9 & 1 & - & - & 1 \\
\hline 29 & 2 & - & 1 & 2 & - & 3 & 12 & 2 & - & 2 & - \\
\hline 30 & 1 & - & - & - & - & 1 & 4 & 2 & - & 1 & - \\
\hline 32 & 1 & - & 5 & 9 & - & - & - & - & - & - & - \\
\hline 35 & 1 & - & 2 & - & - & 1 & - & - & - & 1 & - \\
\hline 36 & - & - & 3 & - & - & 1 & - & - & - & - & - \\
\hline Totals & 55 & 53 & 37 & 28 & 1 & 48 & 64 & 21 & 1 & 10 & 1 \\
\hline \multicolumn{2}{|c|}{ Grand Total } & \multicolumn{10}{|l|}{319} \\
\hline
\end{tabular}


diagnostic historic ceramics (Table 2-5), an approximate mean date of 1856 was assigned to the historic occupation at 41BO184 (Mahoney 2003).

In reference to Table 2-3, a single prehistoric artifact was recovered during the field efforts. One lithic flake was encountered at $0-40 \mathrm{cmbs}$ in $\mathrm{AB} 1$. The flake was associated with a relatively dense layer of oyster shell approximately $10 \mathrm{~cm}$ in thickness. A single brick fragment was recovered in this same level. No stratigraphic separation between the oyster shell layer and the flake and brick fragment was discernible. Given the lack of temporally diagnostic prehistoric artifacts, no date can be assigned to the possible prehistoric component at the site.

The encounter of dense (10-15 cm thick) oyster shell in some of the auger borings (most notably in ABs 1, 2, 20, 21, 22, and 25) indicates the former presence of a historic, lined road or drive. Such paths subject to vehicular traffic were commonly lined with marine and/or estuarine shell along historic coastal sites. Procurement of the requisite quantities of shell to line roads often came at the expense of intact, prehistoric shell middens lining the embayments of the Texas Gulf Coast. Consequently, prehistoric cultural material (i.e., the single flake) could have been procured along with the shell and redeposited as road metal. Also included in the oyster shell layer were crushed chert pebbles, mechanical chert flakes, and a few mollusk specimens (Rangia sp).

Lacking unequivocal evidence for a discrete prehistoric component at $41 \mathrm{BO} 184$, the above scenario is a likely possibility. It is equally possible, however, that a sparse lithic scatter may have existed at the site and has since become turbated into, and indistinct from, the historic occupation.

Table 2-4. Vertical Distribution of Artifacts Recovered during Auger Boring

\begin{tabular}{|c|c|c|c|c|c|c|c|c|c|c|c|}
\hline $\begin{array}{c}\text { Depth } \\
\text { (cmbs) }\end{array}$ & Bone & Brick & Ceramic & Concrete & Debitage & Glass & Gravel & Metal & Mortar & Plastic & Rubber \\
\hline $0-40$ & 54 & 53 & 37 & 28 & 1 & 48 & 64 & 21 & 1 & 10 & 1 \\
\hline $40-80$ & 1 & - & - & - & - & - & - & - & - & - & - \\
\hline $80-120$ & - & - & - & - & - & - & - & - & - & - & - \\
\hline
\end{tabular}

Table 2-5. Seriation of Ceramics Recovered during Auger Boring

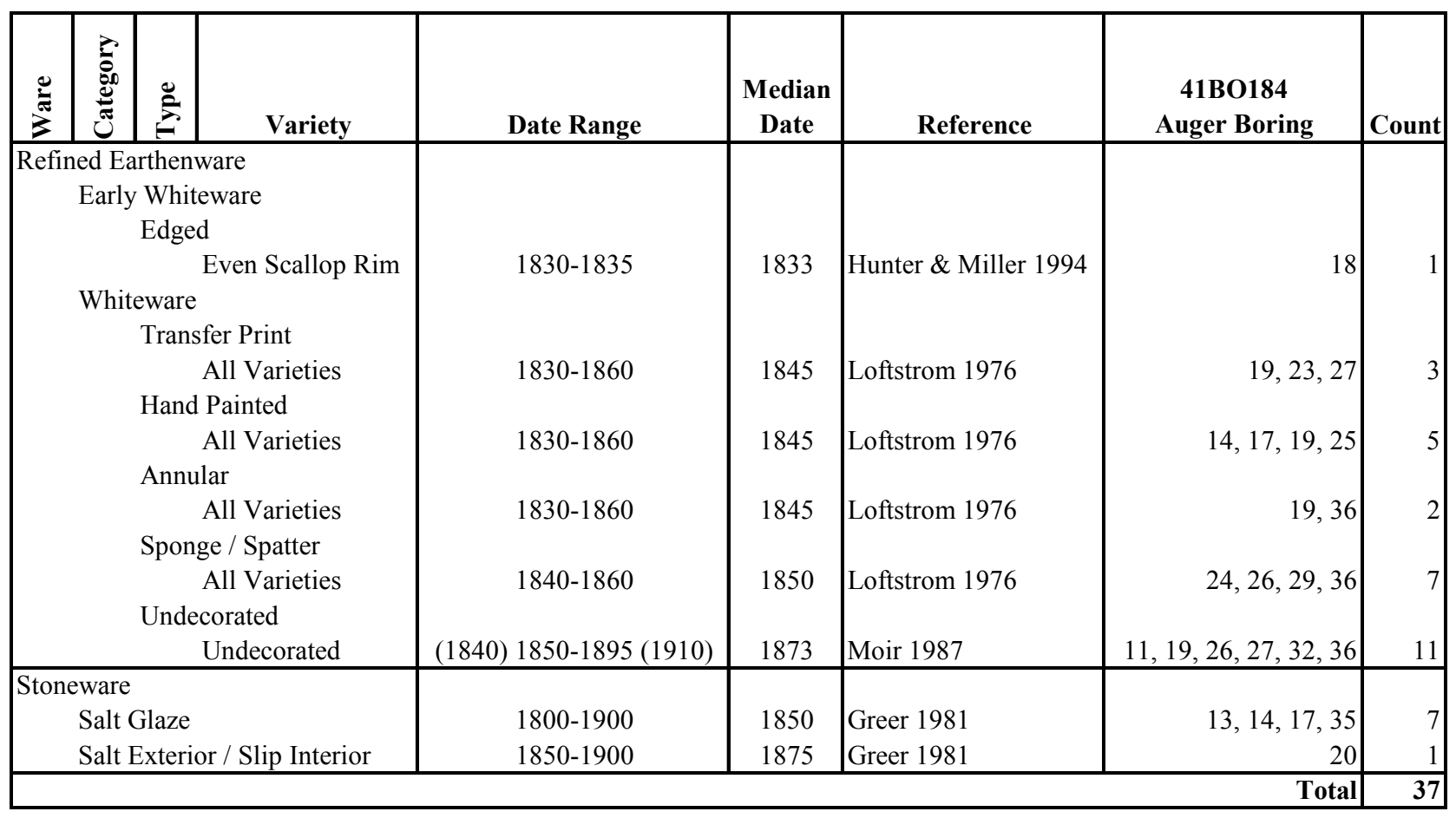




\section{Chapter 3: Research Perspective}

This chapter presents the research perspective that guided the NRHP testing at 41BO184. Based on the results of previous work conducted at the site, only the historic component was addressed with additional testing efforts. Specifically, as the results of the intensive auger boring have demonstrated (Mahoney 2003), the prehistoric material at $41 \mathrm{BO} 184$ is not expressed as a discrete, isolable component and, therefore, does not warrant further investigation.

Archival research carried out by HHM, Inc. (Appendix A) on historic resources of Brazoria County has identified that site 41BO184 is located within the former Variety Grove Plantation established prior to 1850 . The Variety Grove Plantation was established by James Jamison on the leftdescending bank of Oyster Creek. Jamison's homestead was on a tract that was eventually crosscut by both Old SH 35 and new SH 35 (see Appendix A, Figure A-3). By the mid $1850 \mathrm{~s}$, James Jamison's two brothers, Thomas and William, each established their own estates on the large tract of land purchased by their brother. While Thomas settled in an area that is north of the present APE, the archival research conducted by HHM indicates that the William Jamison farmstead was on property immediately north of James' on the left-descending bank of Oyster Creek and within the APE (Figure A-3). James' plantation was primarily involved in raising livestock although it may also have been involved in cotton farming on a limited basis (Appendix A). The 1870s census indicates that William's farm included a grinding mill and several outbuildings including stables, a pig-house, and smokehouses. Also present on the farm were three black servants and a probable slave cabin.

Relatively large-scale and specialized sugar cane and cotton plantations were common in Brazoria County during the nineteenth century. Archeological research on some of these plantations within Brazoria and neighboring counties, such as the Varner-Hogg (Patton) Plantation (Earls and Tomka 1994), the Levi-Jordan Plantation (McDavid 1997), the Anson Jones Plantation (Carlson 1995), and the Lake Jackson Plantation (Few 1999) have contributed and are continuing to contribute valuable information to our understanding of the economic role and social impact of these plantations on communities and regions.

Unfortunately, less is known about the smaller, more diversified plantations that were involved in a variety of economic pursuits and practiced a mix of farming and ranching, and may have also been involved in providing milling services to area planters. It was hoped that if the testing at $41 \mathrm{BO} 184$ resulted in connecting the site to the William Jamison estate, then the information and data gained from these investigations could potentially make a significant contribution to the characterization of the economic and social life of these small-scale mixed ranching and farming operations.

It was this aspect of site 41BO184 that was seen as a valuable contribution to regional historic research. That is, it was felt that if the historic component at the site could yield data to relate it to the Jamison estate and provide details on the make-up of small-scale mixed ranching and farming, the organization of labor, the structure of activity areas and of the site, and the relationship of these ranches to the larger regional economy, the historic component of the site could be considered significant and worthy of listing on the National Register of Historic Places and would warrant designation as a State Archeological Landmark

Prior to the current project, it was not known exactly what relationship site 41BO184 has, if any, to the former William Jamison estate and the Variety Grove Plantation. In addition, it was not known what type of occupation may be represented by the historic materials recovered from the site during the initial investigations. Therefore, the archeological testing associated with the NRHP/SAL eligibility of 41BO184 focused on obtaining data relevant to establishing the relationship of the site to the Jamison estate and defining the type of occupation represented by the historic materials present at the site.

With these research issues serving as central goals, the principal criteria for establishing site eligibility consisted of data types that would allow the definition of the age of the deposits and the nature of the occupation represented at the site. It was hoped that information derived from site testing could potentially provide answers to the following questions:

1) Is the age of the site congruent with the occupation of the William Jamison homestead (1850s-1880s)?

2) What activities were carried out on the site based on the artifacts recovered? 
3) What was the function of the site as indicated by the artifact assemblage recovered from the site and the features that may be present?

It was surmised that data types that could provide answers to these questions may include, but would not be limited, to the following:

1) Temporally diagnostic artifacts such as ceramics and bottle glass with makers' marks;

2) A representative sample of artifacts that allow the characterization of activities carried out on site;

3) Documentation of the spatial relationship between artifacts to define space use as related to site function; and

4) A representative range of intact features that allow the further definition of activities carried out on site and the organization of the activity areas.

While the recovery of the first data type, temporally diagnostic artifacts, would help answer some of the research questions raised above, CAR suggested that the site be considered warranting nomination to the NRHP and/or designation as a SAL only if it contained the fourth data type, intact features.

Given this research context and NRHP/SAL eligibility criteria tied to these broad research issues, the testing excavations at $41 \mathrm{BO} 184$ were designed to focus on the recovery of data (e.g., artifact and feature distributions) relevant to definition of the age of the historic component, site use, site function, and the structure of the activity areas. 


\section{Chapter 4: Methodology}

This chapter details the metal detector survey, manual excavations, and Gradall scraping carried out on 41BO184.

\section{Field Methods}

Following the preliminary literature review, a series of onsite field efforts ensued. As part of the larger SH 35 project (Mahoney et al. 2003), site 41BO184 was initially subject to pedestrian survey to define the surface expression of the site. Following the shovel tests and shovel probes, backhoe scrapes were performed to investigate the nature of the sediments and extent of possible historic and/or modern road base materials. Next, the site was subject to systematic mechanical auger boring to determine the horizontal and vertical extent of cultural material across the site. Finally, during the current project, the actual testing of 41BO184, a systematic metal detector survey was conducted, followed by manual excavation of test units and extensive mechanical stripping to further search for cultural features.

\section{Metal Detector Survey}

As the first step of the current testing efforts, a systematic metal detector survey was conducted across the site. The purpose of this survey was to locate individual metal artifacts and possible features with high metal content. The location of each positive metal detector (MD) signal was pin-flagged and the distribution of the identified metal artifacts was mapped using a total data station. The type of metal and depth of location was recorded for each positive signal encountered.

The metal detector employed, a White's QXT Pro ${ }^{\circledR}$ model, was capable of differentiating various broad groups of metals and a general depth of location. The broad metal categories included large iron; small iron; foil/small ring; nickel/ring; pull-tab/large ring; screwcap/zinc/penny; and coin/silver. While these categories are generally metal-specific (i.e., iron, nickel, zinc), the size and shape of metal artifacts is also apparent in non-metal-specific groups (i.e., nickel/ring, pulltab/large ring, screwcap/zinc/penny). Aside from the test units that were placed atop specific positive metal detector signals, none of the individual signals were ground-truthed.

The survey was conducted with two crew members traversing the project area in approximate $2.5-\mathrm{m}$-wide swaths. One crew member operated the metal detector while the other crew member pin-flagged each positive signal. The survey was conducted west to east, parallel to SH 35, and consisted of ten swaths. A five-meter-wide area adjacent SH 35 was not subject to the metal detector survey due to the large volume of metal debris (i.e., beverage cans) associated with vehicular traffic.

\section{Manual Excavations}

Ten 1-x-1-m test units were excavated to explore the apparent densest portions of the site. Nine of these test units were placed in proximity to auger borings with higher densities of historic cultural material (ABs 5, 10, 14, 17, 19, 24, 26, 32 and 36; see Figure 2-3). Where possible, test units in association with these positive auger borings were situated over nearby positive metal detector hits. Six of the test units were situated over at least one positive MD signal.

All horizontal proveniences were maintained in the 1- $\mathrm{m}^{2}$ units. Based on results from the previous auger borings, excavation of the test units was conducted in arbitrary $10-\mathrm{cm}$ levels. Specifically, since no natural or cultural stratigraphy was noted in the auger borings, and cultural material appeared relegated to the upper $40 \mathrm{~cm}$ of deposits. Four 10-cm levels were dug in each test unit. All manually excavated sediments were screened through $1 / 4$-inch hardware cloth. All cultural material encountered during excavation was collected and recorded on level forms.

\section{Gradall Scraping}

Subsequent to manual excavations, five Gradall scrapes were placed across the apparent center of the site (Figure 4-1). The purpose of these scrapes was to search for cultural deposits or features not located during the previous work. The Gradall scrapes were excavated in 10-cm increments, where possible, to ensure that features and/or deposits would be only minimally disturbed as each layer was removed. In instances where $10-\mathrm{cm}$ increments were not possible (i.e., encounter of large tree roots), care was taken to avoid additional significant impact. In all cases, however, the Gradall scrapes were terminated at a depth of $40 \mathrm{~cm}$ below surface.

\section{Laboratory Methods}

All cultural material recovered was inventoried at the CAR laboratory. All artifacts recovered were identified and analyzed. Processing of recovered artifacts began with 


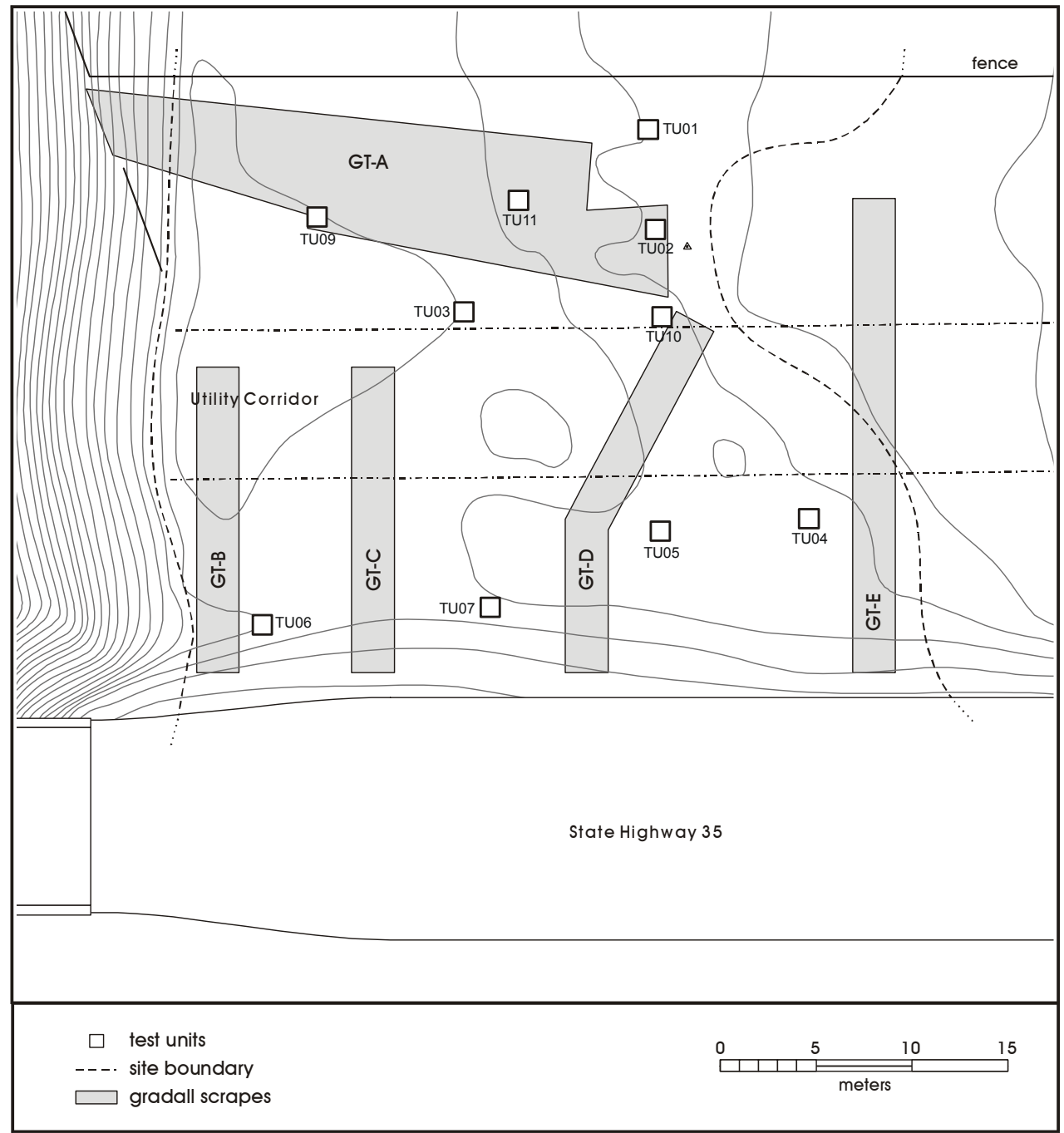

Figure 4-1. Site map with locations of Gradall scrapes and test units.

washing and sorting into appropriate categories (e.g., historic ceramics, glass, unidentified metal). The catalog was entered into an Excel spreadsheet.

All cultural material collected during the survey was prepared in accordance with current state and/or federal regulations. Artifacts processed in the CAR laboratory were stored in archival-quality bags. Acid-free labels were placed in all artifact bags. Each label contains a provenience or corresponding lot number.

Subsequent to proper analyses and/or quantification, recent road trash and artifacts possessing little scientific value were discarded pursuant to Chapter $26.27(\mathrm{~g})(2)$ of the Texas Administrative Code. Artifact classes discarded specific to this project included recent artifacts (i.e., aluminum beer and soda cans, beer and soda bottle shards), gravels, oyster shell, mussel shell, and snail shell. In all instances, discarded materials were documented and their counts included in this report and curation documentation. Discarded materials were disposed of in a manner consistent with suitable disposal procedures.

Field notes, forms, and drawings were placed in archival folders. Documents and forms were printed on acid-free paper. A copy of the testing report and all computer disks pertaining to the investigations were curated with the field notes and documents. After completion of the project, all cultural material and records were curated at the CAR permanent storage facility. 


\section{Chapter 5: Results}

This chapter presents the results of the NRHP eligibility testing at 41BO184. Included in this discussion are the results of previous TxDOT work performed by Christine Ward in 1993 and Allen Bettis in 2001 and 2002. While the site contains both prehistoric and historic components, the latter is represented by a larger sample of artifacts and has received more consideration through analysis. Specifically, as the historic artifact assemblage contains a moderate collection of datable ceramics, more emphasis has been placed on the discussion of these artifacts.

\section{Previous TxDOT Investigations}

The three site visits by TxDOT personnel resulted in the excavation of a total of 13 shovel tests and two Gradall trenches. Six (46\%) of the shovel tests and one of the Gradall trenches were positive yielding prehistoric and/or historic materials. A total of 137 items was recovered from these previous investigations. The majority of these $(\mathrm{n}=106)$ came from the five positive shovel tests excavated in 1994 by Ward (Table 5-1). Interestingly, the only potentially historic artifacts recovered during the 1994 excavations consisted of small brick fragments and a wire nail. Since these items and the animal bone could not definitively be assigned to a historic period, and in light of the lithic debitage $(n=3)$ from the shovel tests, it was assumed that all shell and animal bone finds represented a prehistoric component. Only two artifacts occurred at a depth greater than $50 \mathrm{cmbs}$. The majority tended to concentrate between $10-50 \mathrm{cmbs}$.

The 2001 and 2002 excavations produced 31 artifacts (Table 5-2). Interestingly, 15 (48\%) of these artifacts were historic ceramics and only two items (6\%), a flake and a ceramic sherd, were clearly prehistoric. Both prehistoric artifacts were from Level $5(40-50 \mathrm{cmbs})$, while the historic artifacts concentrated from $20-40 \mathrm{cmbs}$.

The historic ceramics from the TxDOT investigations have been combined with the CAR assemblage and are included in the overall historic ceramic discussion. The one prehistoric body sherd recovered by Allen Bettis can be attributed to the Rockport tradition (Figure 5-1). The paste is sandy to silty in texture and contains burned bone temper and varies from 6 to $8 \mathrm{~mm}$ in thickness. It has been eroded but still exhibits a polished exterior that is typical of burnished surfaces. The exterior is the sandy brown color typical of
Table 5-1. TxDOT 1994 Survey Artifacts

\begin{tabular}{|c|c|c|c|}
\hline Unit & $\begin{array}{l}\text { Depth } \\
\text { (cmbs) }\end{array}$ & Count & Artifact Type \\
\hline \multirow[t]{2}{*}{ ST 4} & \multirow{2}{*}{$\begin{array}{l}40-50 \mathrm{~cm} \\
50-60 \mathrm{~cm}\end{array}$} & 1 & secondary flake \\
\hline & & 1 & secondary flake \\
\hline ST 5 & $0-20 \mathrm{~cm}$ & 1 & invertebrate remains, crab leg \\
\hline \multirow[t]{3}{*}{ ST 6} & $15-20 \mathrm{~cm}$ & 2 & pecan shells \\
\hline & \multirow[t]{2}{*}{$20-30 \mathrm{~cm}$} & 2 & animal bone frags., unidentifiable \\
\hline & & 1 & turtle carapace \\
\hline \multirow[t]{2}{*}{ ST 8} & \multirow[t]{2}{*}{$40-60 \mathrm{~cm}$} & 1 & tertiary flake \\
\hline & & 9 & animal bone frags. \\
\hline \multirow[t]{8}{*}{ ST 9} & \multirow[t]{4}{*}{$0-31 \mathrm{~cm}$} & 30 & oyster shell \\
\hline & & 8 & mussel shell \\
\hline & & 7 & clam shell \\
\hline & & 1 & animal bone (tooth) \\
\hline & \multirow[t]{4}{*}{$31-50 \mathrm{~cm}$} & 29 & mussel shell \\
\hline & & 8 & animal bone \\
\hline & & 4 & brick frags. \\
\hline & & 1 & nail \\
\hline
\end{tabular}

Table 5-2. TxDOT 2002 Testing Artifacts

\begin{tabular}{|c|l|c|l|}
\hline \multirow{3}{*}{ Unit } & $\begin{array}{l}\text { Depth } \\
\text { (cmbs) }\end{array}$ & Count & Artifact Type \\
\hline ST 12 & $20-30 \mathrm{~cm}$ & 1 & olive green bottle shard \\
\cline { 3 - 4 } & & 2 & historic ceramics \\
\cline { 2 - 4 } & $40-50 \mathrm{~cm}$ & 1 & secondary flake \\
\hline Gradall & $30-40 \mathrm{~cm}$ & 2 & animal bone \\
\hline \multirow{5}{*}{ Trench 2 } & & 5 & unidentifiable nails \\
\cline { 3 - 4 } & & 2 & glass (1 green, 1 clear) \\
\hline & & 3 & oyster shell \\
\hline & & 1 & brick \\
\cline { 3 - 4 } & & 13 & historic ceramics \\
\cline { 3 - 4 } & & 1 & Rockport ceramic sherd \\
\hline
\end{tabular}

Rockport specimens; however, the core and interior surface are black. The vessel from which this sherd came was incompletely oxidized (Marybeth S. F. Tomka, personal communication 2004).

\section{Testing Results}

\section{Metal Detector Survey}

The metal detector survey resulted in 122 positive signals. Figure 5-2 depicts the distribution of the positive signals across the site. Table 5-3 presents the types of material signaled, the number and percentage of positive signals per class, and the average depth of the positive signals per class. 


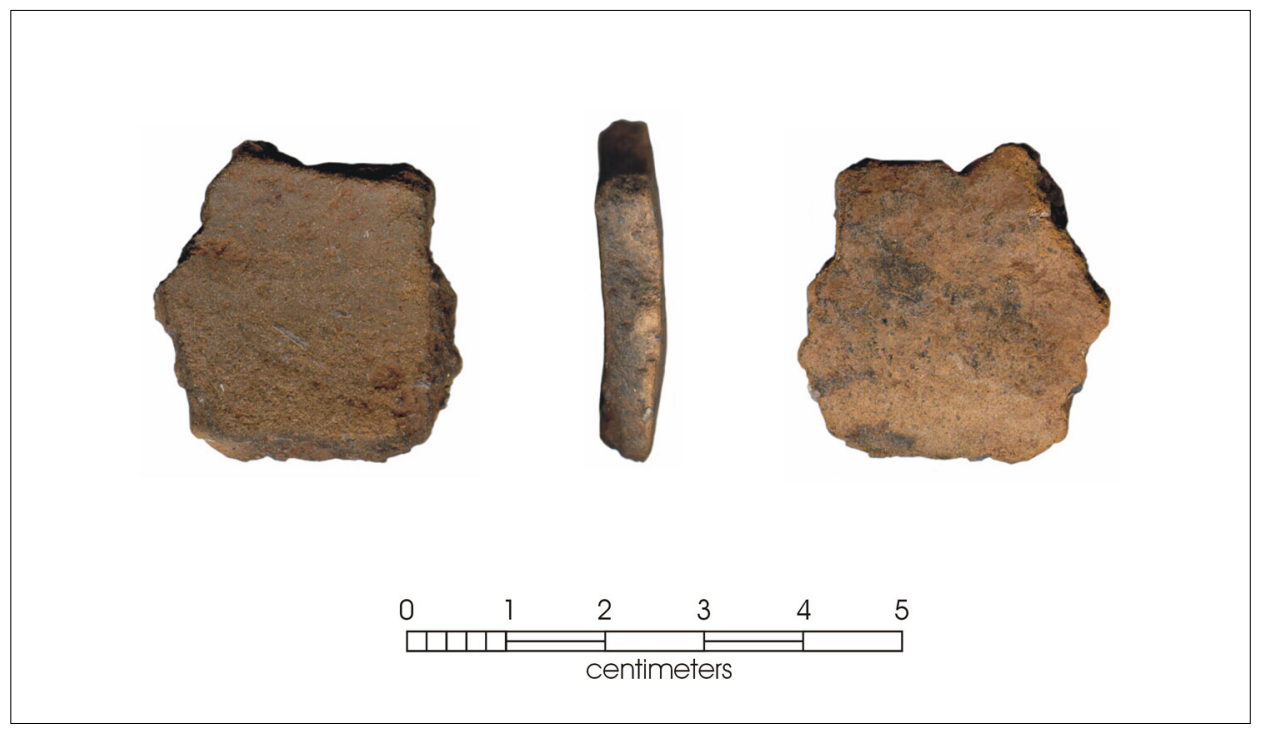

Figure 5-1. Rockport ceramic sherd recovered during the TxDOT 2002 investigations.

The horizontal distribution of positive metal detector hits shows a concentration of items along the SH 35 ROW, at least along the eastern half of the site (Figure 5-2). In addition, two lines of positive hits extend to the north, one following a line between Test Unit (TU) 09 and TU 05 and the other between TU 11 and TU 04. Positive hits are fewer along the western one-third of the site adjacent the creek.

The vertical distribution of positive hits indicates that iron items (large and small) tend to be buried deeper than other categories of finds. We cannot determine whether this pattern reflects that the majority of the iron items are associated with the historic component while other items are road debris. An insufficient number of items were recovered from excavations to allow verification of this possibility.

The most represented of the classes is "large iron," those metal items containing a high content of iron. Conversely, the least represented of the classes is "small iron," those metal items containing a low content of iron. In the instances where a test unit was located over one of the positive signals, the results seem to correspond well with the metal detector's class identification. For example, in the case of TU 11, the three positive signals (MDs 120,121, and 122) all registered as "large iron" with depths of $3.81 \mathrm{cmbs}, 1.27 \mathrm{cmbs}$, and $5.08 \mathrm{cmbs}$, respectively. During manual excavation, MDs 120 and 121 were recovered in the first arbitrary level, and MD 122 was recovered in the second arbitrary level due to a portion of the artifact extending approximately $8 \mathrm{~cm}$ below the upper aspect. All three of these artifacts were portions of the same metal rod.

\section{Manual Excavations}

Ten 1-x-1-m units were excavated across the site to a terminal depth of $40 \mathrm{cmbs}$. A total of $4 \mathrm{~m}^{3}$ of sediment was excavated, which is approximately one percent of the site area and about 0.1 percent of the site volume. No significant cultural features were encountered during manual excavations.

Tables 5-4 and 5-5 present the distribution of artifacts recovered from the ten units excavated (note that number 8 was skipped in the test unit numbering). A total of 1,639 artifacts was recovered. Vertically, the majority $(n=843$; $51.4 \%$ ) of items was recovered from Level 2 , or $10-20 \mathrm{cmbs}$ (see Table 5-4). Over 87 percent of the artifacts came from the upper $20 \mathrm{~cm}$ of deposits. Horizontally, over half $(\mathrm{n}=951$; $58 \%$ ) of the artifacts were recovered from TUs 3 and 7 (see Table 5-5). This latter fact is interesting in that these two test units occur within the apparent oyster shell road base that runs across the site parallel to Oyster Creek. Figure 5-3 depicts the wall profile of completed TU 7. The oyster shell road base shows clearly in the profile.

Similar to the previous auger boring results, the most abundant diagnostic material recovered was historic ceramics. Other historic artifacts include glass shards, cut nails, brick fragments, and animal bone. While various colors of historic glass (non-flat) are present, color alone is not a reliable indicator of age (i.e., Hahn et al. 1994), and no diagnostic bottle fragments were noted in the assemblage. An inspection of the cut nail assemblage reveals that all 


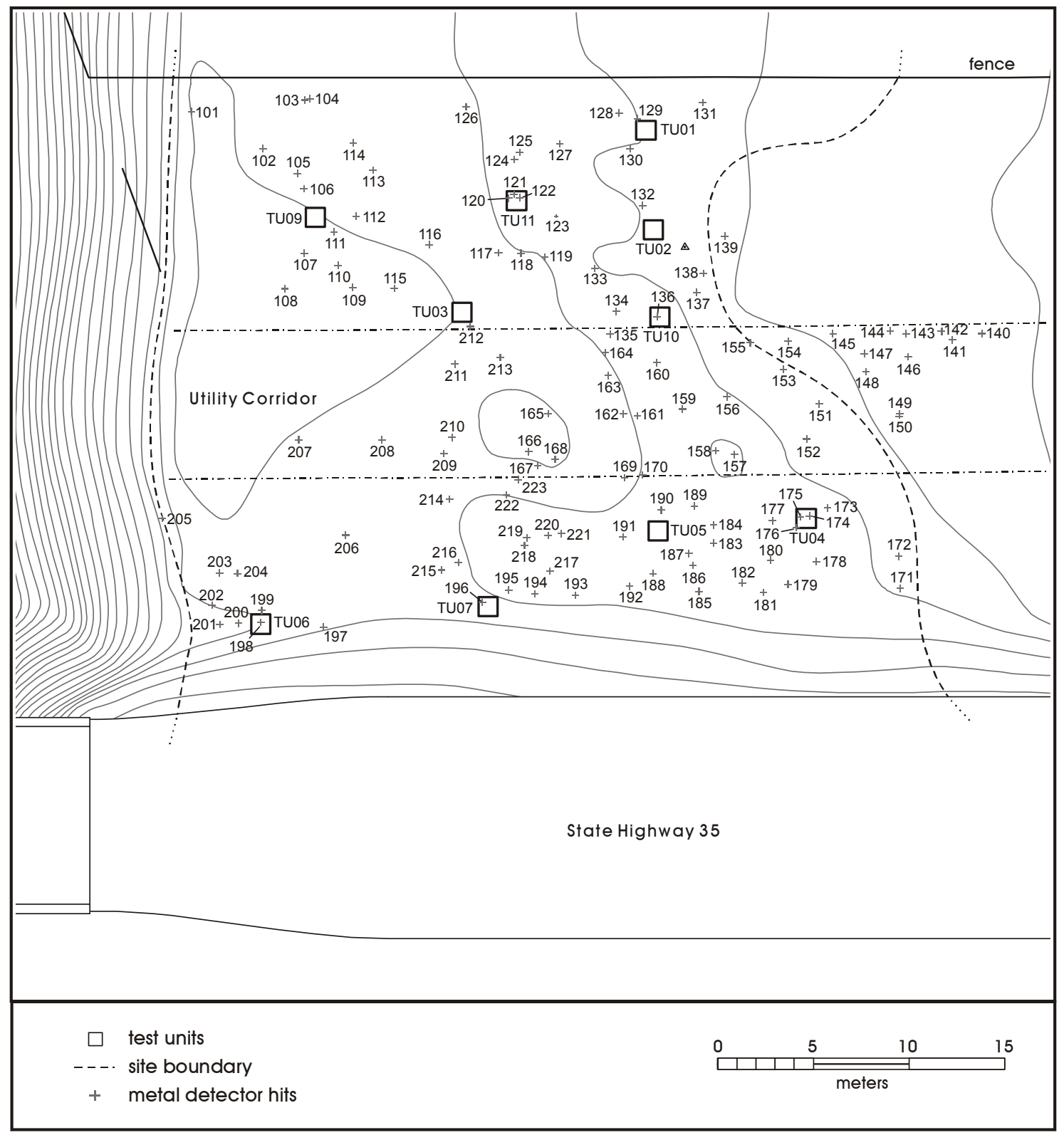

Figure 5-2. Site map with locations of positive metal detector signals and test units.

specimens $(\mathrm{n}=56)$ are machine cut and modern machine headed. The median date of manufacture for these nail types is 1862 . Nearly 300 brick fragments were recovered during the testing phase, though none exhibited any marks that were datable. The faunal analysis identified domesticated species, namely pig and cow. One of the pig bones exhibited a butcher mark consistent with a metal saw blade. Also, a single squirrel innominate showed signs of cut marks. The majority of the specimens were unidentifiable fragments.
In addition to recovery of predominately historic artifacts $(\mathrm{n}=1,627 ; 99 \%)$, a total of 12 prehistoric lithics was recovered. The lithics consist of 11 pieces of debitage and one non-diagnostic tool. The prehistoric material occurs from Level $2(10-20 \mathrm{cmbs})$ through Level $4(30-40 \mathrm{cmbs})$, with the majority $(\mathrm{n}=7 ; 58 \%)$ recovered from Level 2 . While the low count of prehistoric material renders statistical interpretations relatively meaningless, it should be noted that the majority of prehistoric as well as historic materials were recovered from the same arbitrary level at $10-20 \mathrm{cmbs}$. 
Table 5-3. Metal Detector Positive Signals by Class

\begin{tabular}{|l|r|r|r|}
\hline \multicolumn{1}{|c|}{ Class } & & & \multicolumn{2}{c|}{$\begin{array}{c}\text { Average Depth } \\
\text { (cmbs) }\end{array}$} \\
\hline large iron & $\mathbf{n}$ & \multicolumn{1}{c|}{$\boldsymbol{\%}$} & 7.54 \\
\hline small iron & 60 & $49.2 \%$ & 7.62 \\
\hline foil/small ring & 2 & $1.6 \%$ & 1.27 \\
\hline nickel/ring & 6 & $4.9 \%$ & 5.99 \\
\hline pull-tab/large ring & 7 & $5.7 \%$ & 2.94 \\
\hline screwcap/zinc/penny & 19 & $15.6 \%$ & 0.95 \\
\hline coin/silver & 12 & $9.8 \%$ & 2.62 \\
\hline Total & 16 & $13.1 \%$ & 5.13 \\
\hline
\end{tabular}

Table 5-4. Vertical Distribution of Artifacts Recovered during Testing

\begin{tabular}{|c|c|c|c|c|c|c|c|c|c|c|c|c|c|c|}
\hline Level & Bone & Brick & Ceramic & Concrete & Debitage & Glass & Gravel & Metal & $\begin{array}{l}\text { Nail } \\
\text { (cut) }\end{array}$ & Plastic & Rubber & $\begin{array}{c}\text { Lithic } \\
\text { Tool }\end{array}$ & $\begin{array}{c}\text { Level } \\
\text { Totals }\end{array}$ & $\%$ \\
\hline 1 & 40 & 45 & 18 & 43 & 0 & 331 & 39 & 53 & 13 & 7 & 1 & 0 & 590 & $36.0 \%$ \\
\hline 2 & 175 & 197 & 148 & 9 & 6 & 125 & 36 & 116 & 29 & 1 & 0 & 1 & 843 & $51.4 \%$ \\
\hline 3 & 53 & 47 & 46 & 1 & 2 & 15 & 0 & 13 & 14 & 0 & 0 & 0 & 191 & $11.7 \%$ \\
\hline 4 & 3 & 0 & 5 & 0 & 3 & 3 & 0 & 1 & 0 & 0 & 0 & 0 & 15 & $0.9 \%$ \\
\hline Totals & 271 & 289 & 217 & 53 & 11 & 474 & 75 & 183 & 56 & 8 & 1 & 1 & 1639 & $100.0 \%$ \\
\hline
\end{tabular}

Table 5-5. Horizontal Distribution of Artifacts Recovered during Testing

\begin{tabular}{|c|c|c|c|c|c|c|c|c|c|c|c|c|c|c|}
\hline Unit & Bone & Brick & Ceramic & Concrete & Debitage & Glass & Gravel & Metal & $\begin{array}{l}\text { Nail } \\
\text { (cut) }\end{array}$ & Plastic & Rubber & $\begin{array}{c}\text { Lithic } \\
\text { Tool }\end{array}$ & $\begin{array}{c}\text { Unit } \\
\text { Totals }\end{array}$ & $\%$ \\
\hline 1 & 0 & 0 & 0 & 0 & 0 & 70 & 0 & 0 & 0 & 0 & 0 & 0 & 70 & $4.3 \%$ \\
\hline 2 & 13 & 5 & 13 & 0 & 0 & 4 & 0 & 1 & 0 & 0 & 0 & 0 & 36 & $2.2 \%$ \\
\hline 3 & 117 & 87 & 44 & 33 & 1 & 146 & 34 & 28 & 40 & 0 & 0 & 0 & 530 & $32.3 \%$ \\
\hline 4 & 1 & 0 & 18 & 0 & 0 & 180 & 5 & 21 & 0 & 2 & 0 & 0 & 227 & $13.8 \%$ \\
\hline 5 & 52 & 5 & 50 & 10 & 0 & 8 & 3 & 22 & 13 & 2 & 0 & 0 & 165 & $10.1 \%$ \\
\hline 6 & 3 & 6 & 12 & 9 & 0 & 3 & 17 & 23 & 0 & 2 & 0 & 0 & 75 & $4.6 \%$ \\
\hline 7 & 62 & 177 & 48 & 1 & 3 & 32 & 14 & 80 & 2 & 1 & 1 & 0 & 421 & $25.7 \%$ \\
\hline 9 & 3 & 6 & 4 & 0 & 2 & 2 & 0 & 0 & 0 & 0 & 0 & 0 & 17 & $1.0 \%$ \\
\hline 10 & 12 & 2 & 21 & 0 & 3 & 15 & 0 & 3 & 1 & 0 & 0 & 1 & 58 & $3.5 \%$ \\
\hline 11 & 8 & 1 & 7 & 0 & 2 & 14 & 2 & 5 & 0 & 1 & 0 & 0 & 40 & $2.4 \%$ \\
\hline Totals & 271 & 289 & 217 & 53 & 11 & 474 & 75 & 183 & 56 & 8 & 1 & 1 & 1639 & $100.0 \%$ \\
\hline
\end{tabular}




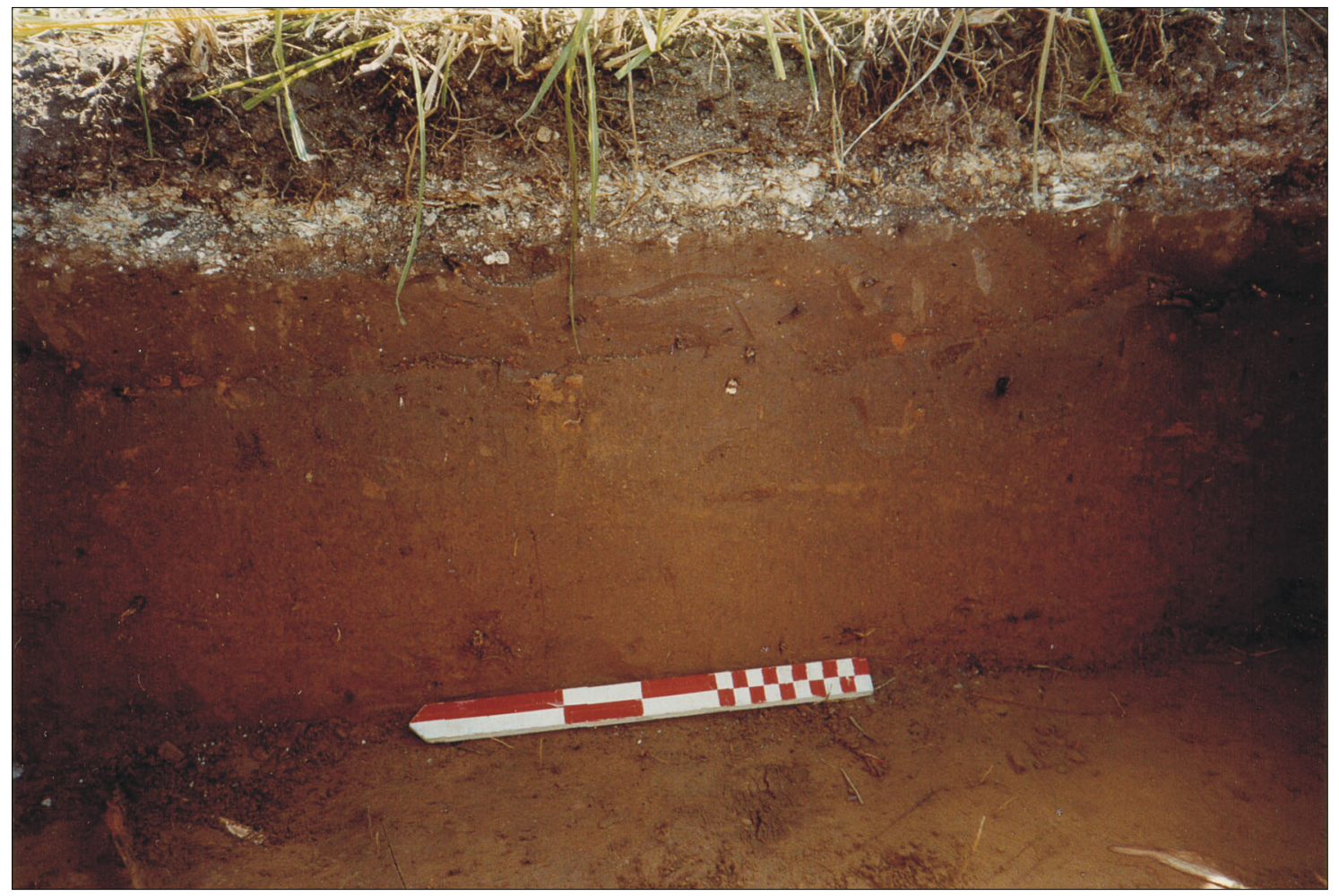

Figure 5-3. Photograph of completed Test Unit 7. Note oyster shell road base in profile.

\section{Gradall Scraping}

Five Gradall scrapes were dug across the site (see Figure 4-1) in an attempt to identify cultural features not previously encountered. Approximately $308 \mathrm{~m}^{2}$ was excavated mechanically to a depth of $40 \mathrm{cmbs}$ (Figure 5-4). Aside from the further delineation of the oyster shell road, no significant deposits or features were encountered. Figure 5-5 depicts the delimited area of the oyster shell road.

\section{Historic Ceramic Analysis}

Historic ceramics recovered from the various investigations at $41 \mathrm{BO} 184$ comprise roughly 12 percent of the overall artifact assemblage. Although the historic ceramic category contained fewer specimens than the individual artifact categories of glass, brick, bone, and metal, the analysis of historic ceramics allows for a more accurate assessment of the occupation of the site. The method of analysis employed for the current study is based on South (1972). More specifically, the manner in which the site is dated is based on median dates of manufacture for a given ceramic ware. Each sherd, then, is assigned a date, and with all sherds sharing equal value, a median date is assigned for the assemblage as a whole. Using this method, the calculated median date for the $41 \mathrm{BO} 184$ collection is 1856 .

The analyzed assemblage consists of 242 identifiable sherds from historic ceramic vessels (Table 5-6). For the purpose of this study, non-vessel ceramics (i.e., tile) were not included in the analyses. In addition, two sherds were omitted from the discussion due to the indeterminate nature of their respective category and type. Both sherds are refined earthenwares, however, they have been subject to probable post-depositional forces, including intense thermal alteration, which has prevented the determination of glaze. Modern ceramics were likewise omitted from this analysis. In cases where cross-mending of sherds was possible, the sherd count was combined to represent one vessel fragment. These deviations should be kept in mind when reviewing the artifact catalog associated with the curated artifacts, as the tabulations used in this discussion are not wholly congruent with the final artifact catalog.

The historic ceramic collection consists of highly fragmented sherds rendering determination of vessel form and size virtually impossible. Although we analyzed the assemblage 
with the goal of defining vessel form/shape, following careful scrutiny of the collection we felt that the small size of the fragments was so limiting that we could not confidently assign individual specimens to formal categories with any confidence and degree of replication. Although not formally quantified, it is estimated that the average sherd dimensions are no more than $2 \mathrm{~cm}^{2}$. Consequently, only one vessel form could be confidently identified, due to the recovery of different sherds that could be cross-mended. No single sherd was sufficiently large enough to determine vessel size.

The vertical distribution of ceramics shows a single mode with 68 percent of the sample recovered by CAR coming from Level 2 (10-20 cmbs; Table 5-4). Almost 90 percent (89.4\%) of the ceramics recovered by CAR are from 10-30 cmbs, suggesting that the assemblage is the product of a single, although not necessarily short, occupation and deposition.

The horizontal distribution of the CAR sample shows that ceramics represent a small proportion $(<10 \%)$ of the artifacts from the three units along the northern edge of the site (TUs 1,9 , and 11). On the other hand, ceramics tend to concentrate in the north-central portion of the site (TUs 2, 3, and 10) where they make up 30-36 percent of the collections from the respective units. The presence of some clustering in ceramics does suggest the preservation of some degree of site structure at $41 \mathrm{BO} 184$.

For this analysis, the overall sample of 242 ceramics was classified by ware, category, type, and variety. Each of these classifications represents a technological or stylistic variant that can be dated based on known periods of manufacture. Table 5-7 presents the classifications used in this report and the respective periods of manufacture. Ware classifications are divided by paste composition and the degree of vitrification of the paste component material. Wares present in the 41BO184 assemblage include coarse earthenwares, semi-refined earthenwares, refined earthenwares, stoneware, and porcelain. The category classification is based on the type of glaze used for a particular ware. Due to the relatively swift succession of ceramic technologies witnessed in the latter part of the eighteenth century and throughout the nineteenth century, particularly for the refined earthenwares, the type of glaze used on a given ware provides a relatively confident means of assessing its temporal affiliation.

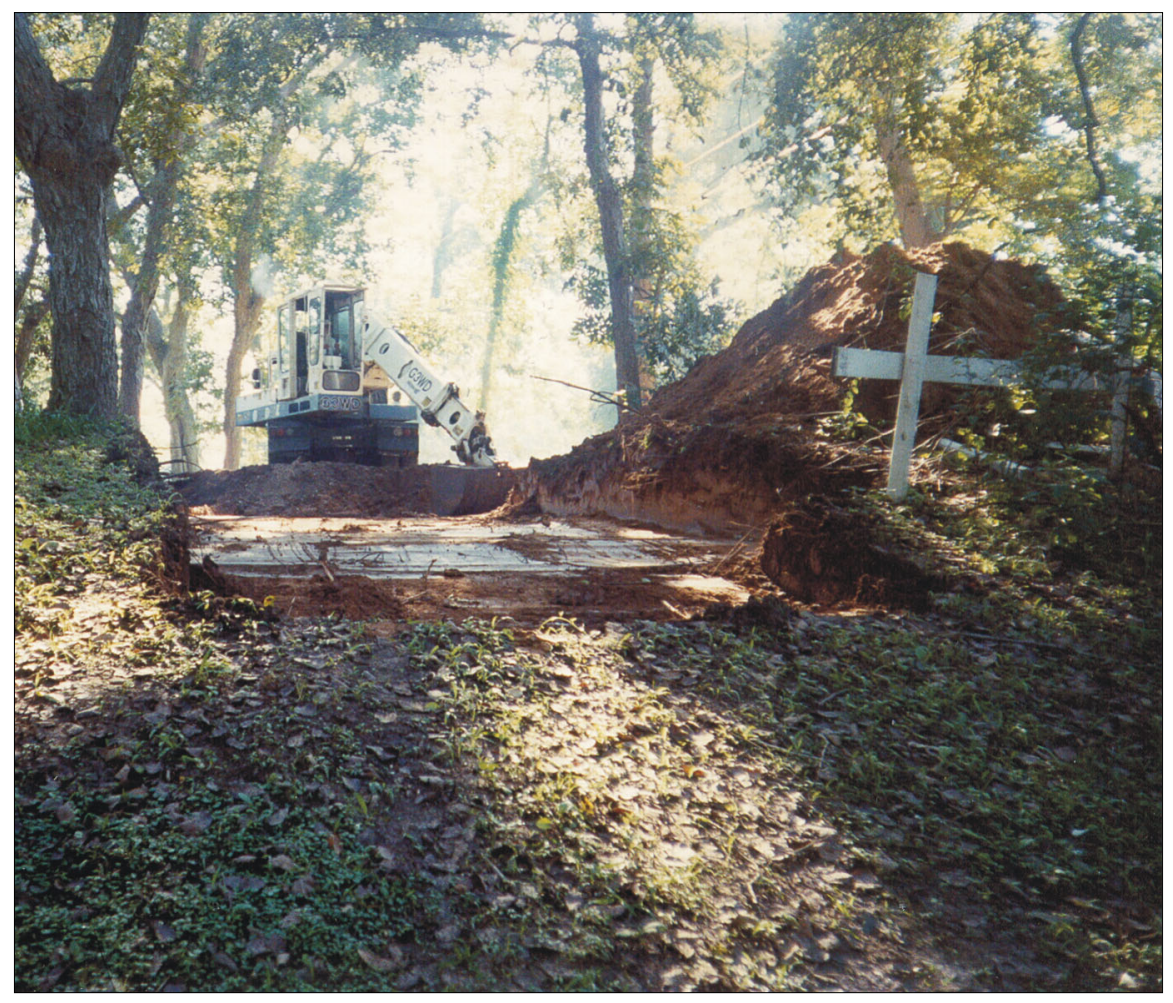

Figure 5-4. Photograph of Gradall scraping in progress. 


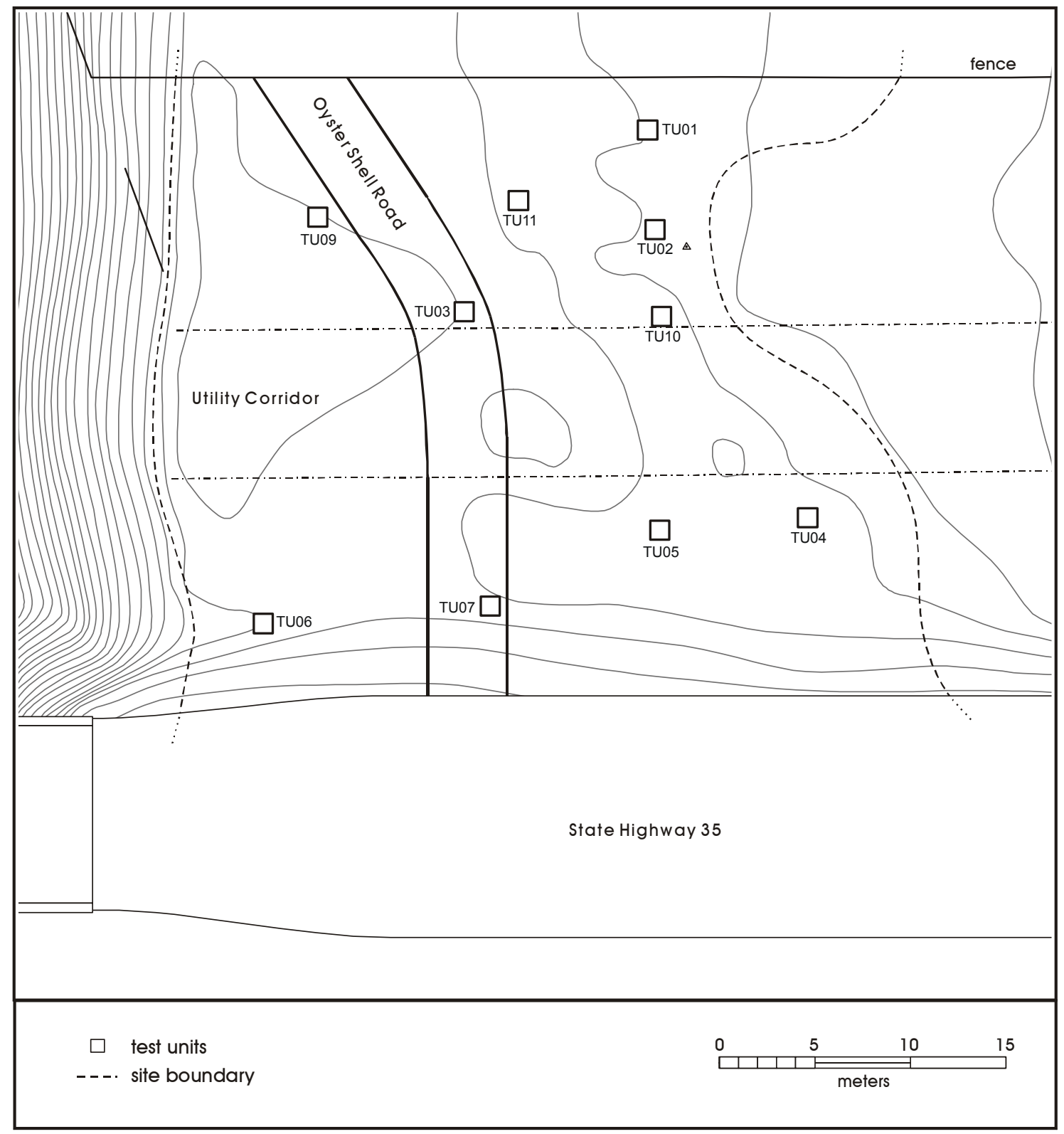

Figure 5-5. Site map with location of oyster shell road and test units.

\section{Coarse Earthenwares}

Only two sherds of coarse earthenware were recovered, representing less than one percent of the total ceramic assemblage. Included in this ware category are one sherd of buffware and one sherd of redware. The buffware sherd has a lead glaze and tin enamel with an unidentifiable underglaze monochrome pattern. Although not definitive, the decorative technique appears similar to that of a brown powdered manganese design (Garner and Archer 1972). The redware sherd has a dull black lead-glazed exterior with a brown saltglazed interior. Lacking any other diagnostic characteristics, the sherd can only be classified to the type of lead glaze, with a median date of manufacture of 1750 (Yakubik 1990). 
Table 5-6. Classification of Historic Ceramics Recovered from 41BO184

\begin{tabular}{|c|c|c|c|c|}
\hline Ware & Category & Type & Variety & Count \\
\hline Coarse Earthenware & Buffware & Tin Enamel & Monochrome & 1 \\
\hline Coarse Earthenware & Redware & Lead Glazed & Black & 1 \\
\hline Semi-Refined Earthenware & Yellowware & Annular & Banded & 2 \\
\hline Refined Earthenware & Creamware & Annular & Banded & 1 \\
\hline Refined Earthenware & Creamware & Undecorated & Undecorated & 1 \\
\hline Refined Earthenware & Ironstone & Blue-Tinted Glaze & Undecorated & 17 \\
\hline Refined Earthenware & Pearlware & Annular & Banded & 3 \\
\hline Refined Earthenware & Pearlware & Edged & Impressed Rim & 1 \\
\hline Refined Earthenware & Pearlware & Hand Painted & Monochrome & 2 \\
\hline Refined Earthenware & Pearlware & Hand Painted & Polychrome & 1 \\
\hline Refined Earthenware & Pearlware & Transfer Print & Blue & 1 \\
\hline Refined Earthenware & Pearlware & Transfer Print & Brown & 1 \\
\hline Refined Earthenware & Pearlware & Undecorated & Undecorated & 14 \\
\hline Refined Earthenware & Whiteware & Annular & Banded & 8 \\
\hline Refined Earthenware & Whiteware & Edged & Impressed, Scalloped Rim & 2 \\
\hline Refined Earthenware & Whiteware & Edged & Impressed, Unscalloped Rim & 6 \\
\hline Refined Earthenware & Whiteware & Edged & Painted, Unscalloped Rim & 3 \\
\hline Refined Earthenware & Whiteware & Hand Painted & Monochrome & 14 \\
\hline Refined Earthenware & Whiteware & Hand Painted & Polychrome & 9 \\
\hline Refined Earthenware & Whiteware & Spatter & Black & 7 \\
\hline Refined Earthenware & Whiteware & Spatter & Blue & 12 \\
\hline Refined Earthenware & Whiteware & Spatter & Dark Blue / Purple & 2 \\
\hline Refined Earthenware & Whiteware & Spatter & Green / Red & 2 \\
\hline Refined Earthenware & Whiteware & Transfer Print & Blue & 13 \\
\hline Refined Earthenware & Whiteware & Transfer Print & Blue Floral & 2 \\
\hline Refined Earthenware & Whiteware & Transfer Print & Purple & 1 \\
\hline Refined Earthenware & Whiteware & Transfer Print & Red Floral & 10 \\
\hline Refined Earthenware & Whiteware & Undecorated & Undecorated & 84 \\
\hline Stoneware & Salt Glaze Exterior & Slip Interior & & 14 \\
\hline Stoneware & Salt Glaze Exterior & & & 4 \\
\hline Stoneware & Slip Exterior & Slip Interior & & 2 \\
\hline Porcelain & Semi-Porcelain & Undecorated & Undecorated & 1 \\
\hline \multicolumn{4}{|r|}{ Total } & 242 \\
\hline
\end{tabular}

\section{Semi-Refined Earthenwares}

Two sherds of yellowware comprise the semi-refined earthenware collection, and, as in the coarse earthenwares, they represent less than one percent of the total ceramic assemblage. The sherds exhibit a semi-vitrified yellow paste, with similar clear lead glazes. These wares were produced during the majority of the nineteenth century and have a median date of manufacture of 1865 (Liebowitz 1985). Decoration consists of an annular type and banded variety. While the sherds cannot be cross-mended, the similarity in thickness suggests that the sherds are from the same or identical vessels.

\section{Refined Earthenwares}

Roughly 90 percent $(n=217)$ of the ceramic assemblage consists of refined earthenwares. Included in the assemblage are sherds of creamware, pearlware, whiteware, and ironstone. Various decorative techniques are present in the assemblage, with examples of hand-painted, transfer print, spatter, edged, and annular wares. Numerous varieties are contained in the collection and will be discussed under the general type classifications that follow. 
Table 5-7. Classification of Ceramics with Dates of Manufacture

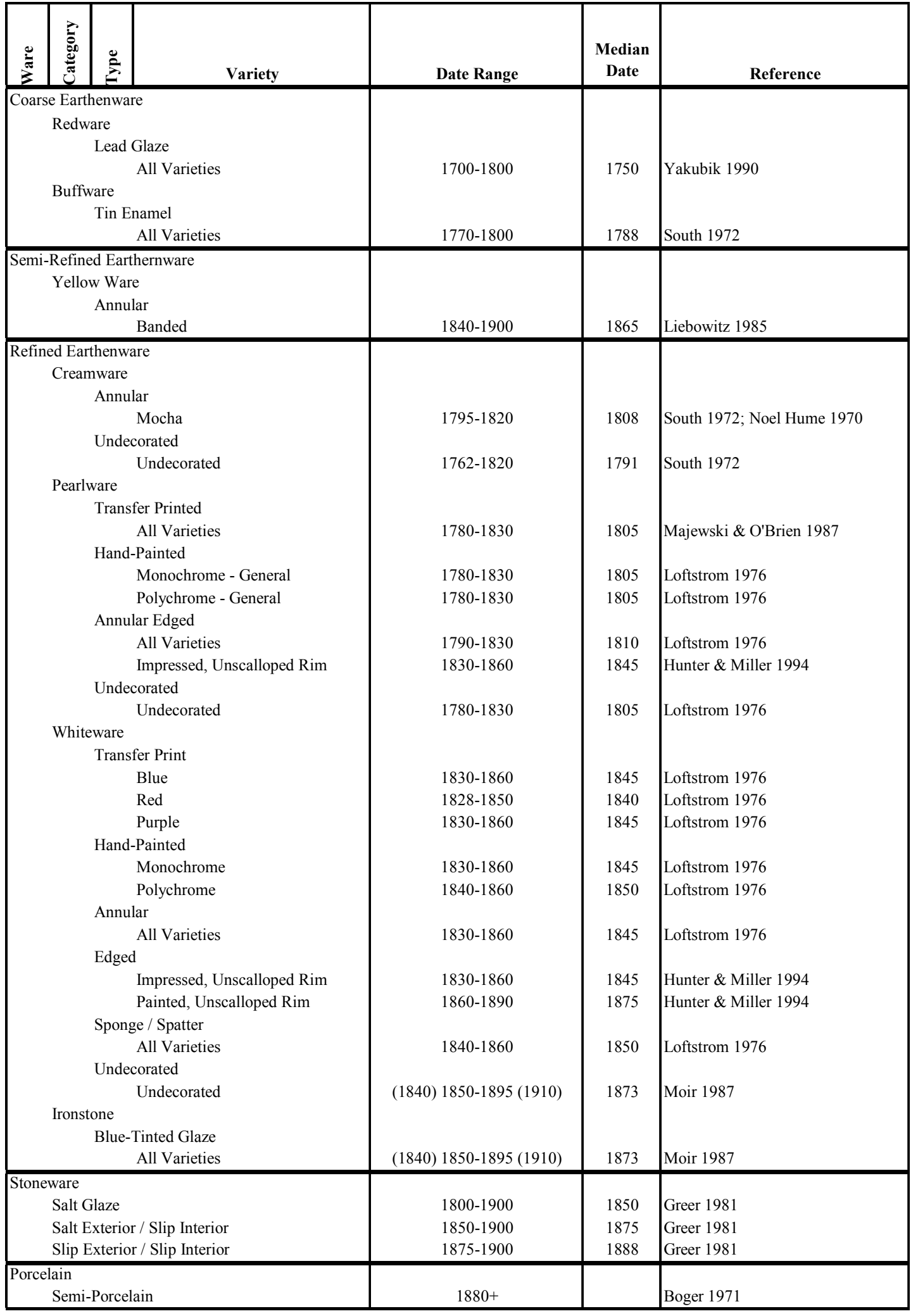




\section{Creamware}

Only two examples of creamware were recovered, representing less than one percent of the ceramic assemblage as a whole and less than one percent of the refined earthenwares. One undecorated sherd and one decorated sherd are present. Manufacture of these ceramics, together with the coarse earthenwares, predates the occupation of the William Jamison homestead by at least half of a century. The sherds suggest the presence of curated vessels in the Jamison household that were broken and subsequently discarded at 41BO184. If an earlier occupation was present at 41BO184, then we would expect to see a greater number of early ceramics and other historic artifacts.

Statistically, the presence of these early sherds in the assemblage affects calculation of the date of the site only slightly. If we remove the two coarse earthenware sherds and the two creamware sherds from the calculation, less than one year is added to the calculated date of occupation.

Of interest in the small creamware classification is the presence of a decorated specimen (Figure 5-6a). The crossmended sherd is of the annular type and mocha variety. Chronologically, this decorative motif would place the vessel in the late eighteenth century to early nineteenth century, with a manufacturing date range of 1795 to 1820 and a median date of manufacture of 1808 (Noël Hume 1970). However, the slip decoration termed "cable," or "earthworm," suggests association with the latter part of the manufacturing date range, possibly 1811-1820 (Carpentier and Rickard 2001:126).

\section{Pearlware}

Pearlware sherds $(n=23)$ comprise the second most numerous wares, with 11 percent of the refined earthenware class and 10 percent of the overall ceramic assemblage. Decorative techniques represented in the collection include hand-painted, annular, transfer print, and edged. Undecorated sherds $(\mathrm{n}=14)$ outnumber decorated sherds, although due to the extremely fragmented nature of the assemblage, it is likely that these undecorated sherds are simply undecorated portions of decorated vessels. This assertion is based on the fact that very few undecorated pearlware vessels were produced (Miller 1980:16), probably as a result of the popularity of decorated wares during the primary pearlware manufacturing period of 1780 to 1830 (Hunter and Miller 1994; Lofstrom 1976).

\section{Hand-Painted}

Three hand-painted sherds account for one-third of the decorated pearlwares. Each of the specimens contains an unidentifiable floral pattern with some green visible in the form of leaves or stems. Two of the sherds are classed as monochromatic, as only portions of green leaves are visible. It is probable that the decoration(s) on these vessels contained more than the single color present on the sherds, however, the extremely small surface area reveals only a portion of the design. As such, the catchall variety of monochrome-general (Lofstrom 1976) has been assigned to these two sherds. Similarly, the third sherd exhibits a floral design, although in addition to the green stems, portions of dark, yellowish brown leaves are visible. While this sherd is roughly twice the size of the two previous sherds, a sufficient amount of the design was not present to determine the variety. The polychrome-general variety (Lofstrom 1976) was assigned to this vessel fragment.

\section{Annular}

As with the hand-painted type, annular fragments similarly account for one-third of the decorated pearlwares. Two of the sherds exhibit narrow blue bands near the rim of the vessel. One of these blue-banded sherds has a single band only on the interior, while the other blue-banded sherd possesses similar banding on the interior and exterior. The third sherd is a mocha variety, with alternating dark brown and white bands over a mocha background.

\section{Transfer Print}

Two transfer print pearlware sherds are included in the collection. One of the sherds has an indeterminate blue design, probably the most popular of the color varieties available during the production of pearlwares (Noël Hume 1972). The second sherd is a cross-mended fragment of the brown color variety. Although incomplete, the design appears to be part of the upper portion of an ornate structure such as a castle or temple (Figure 5-6b). While a definitive match for the pattern was not found, the design appears reminiscent of the "Solar Rays" pattern identified in the Old Velasco (41BO125) collection (Pollan et al. 1996).

\section{Edged}

A single blue edged decorated pearlware fragment was recovered. The decorative technique employs a "feather" impressed or molded design along the rim of the vessel, with 


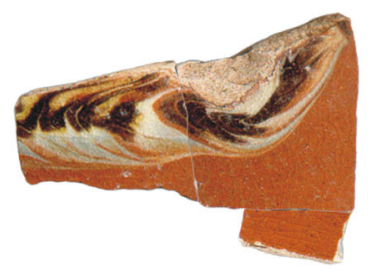

a

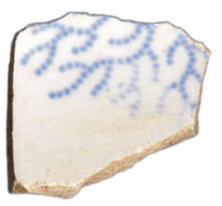

C

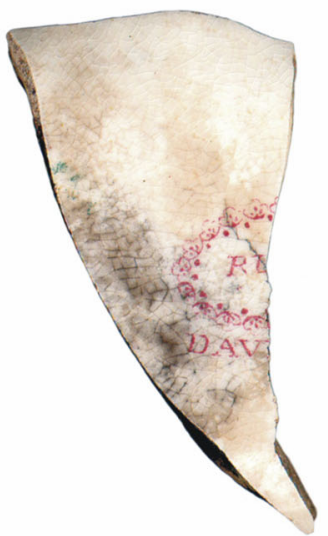

f

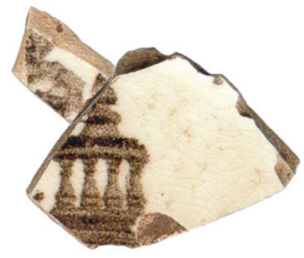

b

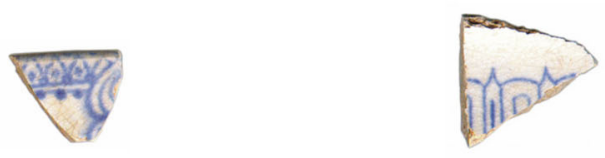

d

e

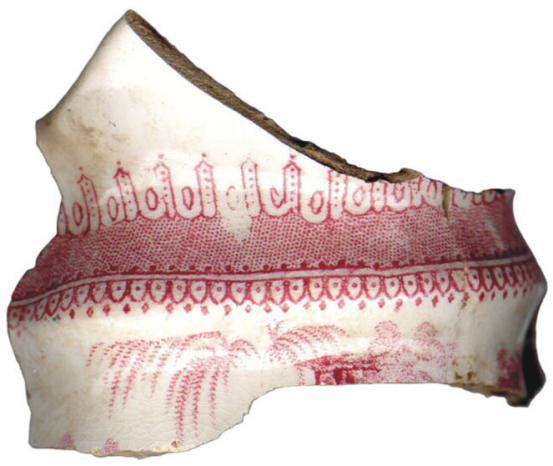

9

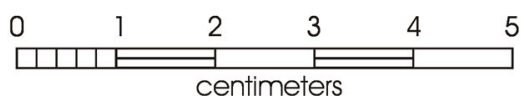

Figure 5-6. Selected historic ceramics recovered from 41BO184. a) annular type, mocha variety creamware; b) transfer printed pearlware; c) "Agricultural Vase" transfer printed whiteware; d) "Muleteer" transfer printed whiteware; e) "Palmyra" transfer printed whiteware; f) Davenport "Rural" transfer printed whiteware; g) transfer printed whiteware creamer fragment. 
alternating long and short "feathers." The rim lip is not present on the sherd, and it cannot be determined whether the vessel possessed a scalloped or unscalloped rim surface. Hunter and Miller (1994) note the production date of the scalloped variety during the last quarter of the eighteenth century.

\section{Whiteware}

Whiteware sherds comprise the majority $(n=175 ; 72 \%)$ of the overall ceramic assemblage from 41BO184. Decorated whiteware sherds $(n=91)$ slightly outnumber undecorated sherds $(n=84)$ suggesting a mid-nineteenth century median date as opposed to a late-nineteenth century median date. This earlier date is based on the apparent greater popularity of decorated wares in the earlier part of the nineteenth century as opposed to the years of 1850-1875 (Miller 1980). Decorations represented in the collection include transfer print, spatter, hand-painted, edged, and annular types.

\section{Transfer Print}

Transfer print sherds $(\mathrm{n}=26)$ form the largest percentage (29\%) of decorated specimens in the whiteware collection. Fifteen blue design sherds of indeterminate pattern dominate the transfer print type, followed by ten red floral sherds and only one purple design sherd. Each of the transfer print sherds were compared to the assemblages recovered from archeological investigations at the historic sites of Quintana (41BO135; Blake and Freeman 1998) and Old Velasco (41BO125; Earls et al. 1996; Pollan et al. 1996). These two towns were located on opposite banks of the Brazos River near its mouth at the Gulf of Mexico. Their proximity to site $41 \mathrm{BO} 184$ is significant in that both were noted centers of commerce during the early Texas Republic period and likely supplied a good portion of the inhabitants of Brazoria County with English wares.

Despite the excellent documentation provided in the Quintana and Velasco reports, only three transfer print patterns could be positively identified. Many more previously identified patterns probably exist within the 41BO184 collection, however, the fragmented condition of the collection has thwarted the effort of pattern identification for the majority of the assemblage. Of the three identified patterns from 41BO184, one is the "Agricultural Vase" pattern (Figure 5-6c) as identified in Pollan et al. (1996:17) and in Blake and Freeman (1998:26). The makers identified in Pollan et al. (1996:17) are Ridgeway, Morley, Wear \& Co.; Ridgeway and Morley; and Francis Morley \& Co. The date of production for the various manufacturers is 1836 to 1858 , with a median date of 1847 . The manufacturer identified for the Blake and Freeman (1998:26) specimens was Ridgeway, Morley, Wear \& Co., with a slightly earlier median date of manufacture of 1839 .

A second identified pattern from 41BO184 is the "Muleteer" design (Figure 5-6d). Similar to the "Agricultural Vase" pattern, the ware was encountered at both Velasco (Pollan et al. 1996:55) and Quintana (Blake and Freeman 1998:85). The vessel fragments recovered from Velasco are identified as products of Davenport, with a manufacturing date range of 1836 to 1887 (Pollan et al. 1996:55). The fragments recovered from Quintana are similarly attributed to Davenport; however, a manufacturing date range of 1820 to 1860 is ascribed due to the presence of a pattern cartouche backmark (Blake and Freeman 1998:85).

The third identified pattern from 41BO184 is the "Palmyra" design (Figure 5-6e). As in the other two identified patterns, the "Palmyra" design was recovered at Velasco (Pollan et al. 1996:127) and Quintana (Blake and Freeman 1998:93). The manufacturer of the vessel fragments recovered from Velasco and Quintana was identified as Thomas Furnival \& Co., with a manufacture date range of 1845 to 1846 (Blake and Freeman 1998:93; Pollan et al. 1996:127). Although not pictured in the Velasco publication, the Quintana document clearly depicts the unique well wreath string design shown in Figure 5-6e.

Only two backmarks, or maker's marks, are present in the $41 \mathrm{BO} 184$ ceramic collection. One of these backmarks simply contains the letter "E" in a blue mark. None of the backmarks described or illustrated in the Velasco and Quintana reports match this single letter backmark. It is probable, though, that more letters were originally part of this mark, but due to the small size of the fragment, the "E" is all that remains. The spacing following the " $E$ " makes it likely that the letter stood alone and was not part of a word or maker's initials, such as the "EKB" of Elkin, Knight \& Bridgwood (Pollan et al. 1996:87). One possibility, though, is a backmark for the " $E$ is the "Engine" pattern recovered from Quintana (Blake and Freeman 1998:56). However, the Quintana specimen was printed in green and lacked a backmark. Consequently, based on the limited data, no manufacturer affiliation can be assigned to this transfer print sherd.

The second backmark observed in the collection is a red floral cartouche with the letters "RU" inside of the cartouche and the letters "DAV" underneath the cartouche (Figure 5-6f). Noting the position of "DAV" relative to the curvature 
of the cartouche in Figure 5-6f, the manufacturer is doubtless Davenport. While the Velasco report alone has over 30 photographs of Davenport wares, with at least 10 backmarks depicted, none matched this red floral specimen. The Quintana report similarly lacked any Davenport examples that would provide positive identification. Nevertheless, a brief reference is made in the Quintana report (Blake and Freeman 1998:Table 1) of a "Rural" transfer print pattern present at both town sites. The character spacing in our "RU" backmark relative to the surrounding cartouche is consistent with the space required for a five-letter word. The backmark depicted in the Velasco report (Pollan et al. 1996:67) does not match our Davenport "RU" backmark, however, the Quintana report does not illustrate their "Rural" backmark. Further comparisons will need to be made to determine whether the Quintana specimen is a match for the Davenport "RU" sherd from 41BO184. Similar to the "Muleteer" pattern referenced earlier, the presence of the Davenport cartouche backmark suggests a manufacturing date range of 1820 to 1860 .

Although unable to cross-mend, the Davenport "RU" backmark sherd appears consistent in thickness and design color to the only identifiable ceramic vessel form from 41BO184, a tea set creamer fragment (Figure 5-6g). Another similar characteristic shared by these two sherds, and at least one other sherd, is the apparently recent burn episode evidenced by soot adherence and slight thermal alteration to portions of the glaze. In addition to these three burned sherds, at least six other sherds with portions of a similar red floral print are contained in the whiteware transfer print assemblage. While it is possible that all of these red floral pattern sherds are from the identified creamer vessel, it should be noted that none of these sherds cross-mend.

\section{Spatter}

Twenty-three sherds with an applied spatter decorative technique were recovered. This sherd type, along with handpainted sherds, make up the second largest category of decorated whitewares, at 25 percent each. Blue sherds $(\mathrm{n}=12)$ comprise the majority $(52 \%)$ of the spatter type sherds and represent the only monochrome scheme present. The remainder of the spatter assemblage consists of polychrome combinations, including black with brown $(\mathrm{n}=7)$, purple with dark blue $(\mathrm{n}=2)$, and green with red $(\mathrm{n}=2)$. Lofstrom (1976) ascribes a manufacture date range from 1840 to 1860 , with a median date of manufacture of 1850 .

\section{Hand-Painted}

As in the spatter type, the hand-painted type consists of 23 sherds representing one-quarter of the decorated whiteware assemblage. Monochrome sherds $(n=14)$ outnumber polychrome sherds $(n=9)$, however, the smallness of the sherds in the monochrome variety may simply represent monochrome portions of polychrome vessels. Of the 14 monochrome sherds, blue dominates the variety with over 70 percent of the total. The balance of monochrome sherds is comprised of green $(n=3)$ and red $(n=1)$. All of the polychrome sherds exhibit green as one of the colors, suggesting a later floral motif, as opposed to an earlier oriental motif (Miller 1980). The median date of manufacture is 1845 for the monochrome variety and 1850 for the polychrome variety (Lofstrom 1976).

\section{Edged}

Only 11 sherds of edged, or "shell edge," whiteware were recovered, representing roughly six percent of the whiteware assemblage and about 12 percent of the decorated whiteware assemblage. Of the 11 edged sherds, 10 are blue and one is green. Five of the blue sherds, along with the single green sherd, exhibit an impressed, unscalloped rim. Two of the blue sherds have an impressed, scalloped rim. The eight sherds exhibiting impressed rims share a manufacture date range of 1830 to 1860 , with a median date of 1845 (Hunter and Miller 1994). The remaining three blue sherds lack the impressed rim and have only a painted, unscalloped rim. Hunter and Miller (1994) date these much later than the impressed vessels, with a median date of manufacture of 1875 .

\section{Annular}

Eight sherds comprise the annular whiteware type. The annular type represents less than five percent of the whiteware assemblage. Each of the annular sherds is of the banded variety. Three colors are included in the banded variety: red $(\mathrm{n}=4)$, brown $(\mathrm{n}=2)$, and blue $(\mathrm{n}=2)$. Lofstrom (1976) suggests the banded variety, along with all of the whiteware annular varieties, were manufactured from 1830 to 1860 , with a median date of manufacture of 1845 .

\section{Ironstone}

Seventeen sherds of ironstone, or "Granite White," were recovered, comprising approximately eight percent of the refined earthenware assemblage. None of the sherds 
exhibited decoration, as is typical of this ware (Miller 1980). Moir (1987) gives a primary manufacture date range of 1850 to 1895 for ironstone, with a median date of 1873 .

\section{Stoneware}

Twenty stoneware sherds were recovered. Stoneware ranks a distant second to refined earthenwares in rate of recovery, with roughly eight percent of the total ceramic assemblage compared to refined earthenwares with about 90 percent of the total ceramic assemblage. Of the 20 stoneware sherds, the majority $(70 \%)$ exhibit a salt glaze exterior with a slip interior. Greer (1981) indicates a manufacturing date range of 1850 to 1900 for this type of stoneware. Twenty percent of the stoneware assemblage exhibits only a salt glaze exterior. This type of stoneware was produced throughout the nineteenth century and has a median date of 1850 (Greer 1981). The final ten percent of the stoneware assemblage exhibits a slip exterior and slip interior. Greer (1981) places these at the final quarter of the nineteenth century with a median date of manufacture of 1888 .

\section{Porcelain}

A single sherd of semi-porcelain was recovered. The sherd exhibits a vitrified paste and a glossy, translucent glaze. The small sherd is undecorated. Boger (1971) suggests a date range of manufacture from 1880 to the present for these wares. Calculating the date range of from 1880 to 2000, the median date of manufacture would be 1940 .

\section{Discussion}

As previously mentioned, the historic ceramic assemblage from 41BO184 consists of an extremely fragmented collection of 242 sherds. With one exception, the sherds could not be identified to specific vessel form. Although not entirely quantified, it is estimated that less than onequarter of the assemblage could be assigned to general vessel form categories of flatware and hollowware. In reference to Miller $(1980,1991)$ though, the utility of classification of only a small portion of the assemblage to these general categories did not seem warranted. Specifically, the ability to determine the type of ware and decorative technique employed on nearly all of the ceramic assemblage weighed as a more valuable analytical tool than identification of the general classification of vessel form of only a small portion of the assemblage.
Analysis of the assemblage has determined a median date of manufacture of 1856. The date ranges provided for the 41BO184 historic ceramic sample show that only a few specimens in the sample have date ranges prior to 1800 (Table 5-7). Specifically, a maximum of only 27 ceramic sherds ( 2 coarse earthenware; 2 creamware; and 23 pearlware) could have been manufactured prior to 1800 . On the other hand, as many as 175 specimens ( $72 \%$ of which are whiteware) were most likely manufactured between 1830 and 1860 . Only a few specimens $(n=27 ; 6$ edge painted, unscalloped; 20 stoneware; 1 porcelain) have manufacture dates later than 1860 .

These overall patterns suggest that the ceramic assemblage was deposited sometime between 1830 and 1890 . The pre1800 specimens could represent curated items while the post-1860s specimens probably represent items acquired late in the occupation of the site. It is likely that the most intensive occupation of the site occurred between 1830 and 1860around the median date of 1845 . The median manufacture date reflected by the entire collection is 1856 . This date is congruent with the occupation of the Jamison homestead along Oyster Creek, as determined through archival research (see Appendix A). While earlier ceramics such as coarse earthenwares and creamwares were recovered, their presence is likely due to curated items in the Jamison household and is not indicative of an earlier historic occupation at $41 \mathrm{BO} 184$.

While Miller $(1980,1991)$ has provided very detailed price indices for ceramics from the nineteenth century, he notes that socioeconomic inferences of an occupation are virtually meaningless when based on ceramic assemblages associated with occupations spanning over two decades. Therefore, because the date ranges for ceramic manufacture suggest at least a 30-year and perhaps as long as a 60 -year occupation, the economic indicators of the ceramic assemblage from 41BO184 were not considered in this analysis. 


\section{Chapter 6: Summary}

Site 41BO184 is interpreted as a multicomponent site, possessing both a Late Prehistoric component and an antebellum historic component. The predominant component, the historic, is represented by numerous ceramic sherds, glass shards, bone fragments, handmade brick fragments, and cut nails. The sparse prehistoric component is represented by 13 lithic artifacts and a ceramic sherd.

The historic component appears to be an artifact scatter representative of a variety of activities including food preparation and serving, day-to-day maintenance activities, and construction. The lack of features, the small size of many of the artifacts, and the absence of organic deposits characteristic of trash dumps suggests that the historic materials represent secondary disturbed deposits. The presence of a shell-paved driveway near the center of the site suggests that the current status of the historic collection could be the result of demolition and/or construction activities associated with this road.

Nonetheless, the concentration of the historic materials within a 30 -cm-thick zone and the relatively narrow date range (1830-1860) suggested for the majority of the ceramics implies that, with the exception of some road trash, the materials are derived from a historic occupation at the locale. Based on the detailed analysis of ceramics recovered during the TxDOT and CAR investigations, the median date of manufacture of these artifacts was determined to be roughly 1856 . This date is consistent with William Jamison's occupation of the homestead.

The recovery of a single Rockport ceramic sherd suggests that prehistoric component dates to the Late Prehistoric period. The 13 chipped lithic artifacts recovered from the site are non-diagnostic both temporally and technologically.

Previous excavations by TxDOT included 13 shovel tests and two Gradall trenches. Exploratory excavations by CAR consisted of two shovel tests, 13 shovel probes, two backhoe scrapes, and 36 auger borings. The current test excavations included ten $1-\mathrm{m}^{2}$ test units and six Gradall scrapes. While nearly 2,000 artifacts were recovered during the combined TxDOT and CAR excavations, no significant, intact cultural deposits or features were encountered.

In the research perspective for this project, we outlined three specific questions that the testing efforts should address in order to define the type of occupation represented by the cultural material recovered. Based on our analyses, only the first question (Is the age of the site congruent with the occupation of the William Jamison homestead [1850s1880s]?) can be confidently answered. Although preliminary analyses failed to identify significant numbers of functional classes of artifacts, it was hoped that formal artifact analyses would provide sufficient information to address the second question: What activities were carried out on the site based on the artifacts recovered? Unfortunately, the systematic analysis of the ceramics from the site reinforced our initial impressions that the ceramics were heavily reduced in maximum dimension. The small size of the fragments has in turn prevented us from classifying any historic sherds into functional categories. Therefore, the more systematic and detailed analysis of the ceramic collection failed to precisely define the use and function of the historic component at 41BO184. The final research question (What was the function of the site as indicated by the artifact assemblage recovered from the site and the features that may be present?), cannot be fully answered as no features were encountered at the site.

In summary, as per the parameters of NRHP/SAL eligibility criteria established in the scope of work accompanying Texas Antiquities Permit No. 3210, site 41BO184 is determined ineligible for listing on the National Register of Historic Places or for designation as a State Archeological Landmark. Specifically, while the prehistoric and historic age of the deposits can be established, and the artifacts seem to derive from a historic occupation of the locale, the artifact numbers are too few and the artifacts too small to characterize the activities carried out on site (i.e., site use, site function). In addition, although some spatial patterning of artifacts was noted, no intact features were located to address the organization of activity areas. As such, only the first question posited in the Research Perspective can be confidently answered. Analysis of the historic ceramics recovered during the two phases of work by TxDOT and the CAR investigations indicates a median date of manufacture of 1856, a date consistent with the occupation of the William Jamison homestead. Although this date does not necessarily establish the site as part of the Jamison homestead, it does strengthen the possibility that the site is in some manner related to it. Nonetheless, lacking sufficient sample sizes and the necessary data types (i.e., intact features) to address the research topics listed in the Research Perspective, it is recommended that no further cultural resource investigations are required for $41 \mathrm{BO} 184$. 


\section{References Cited}

Blake, M. E., and M. D. Freeman

1998 Nineteenth-Century Transfer-Printed Ceramics from the Texas Coast: The Quintana Collection. Prewitt and Associates, Inc., Austin.

Boger, L. A.

1971 Dictionary of World Pottery and Porcelain. Scribner, New York.

Carlson, S. B. (editor)

1995 The Anson Jones Plantation: Archaeological and Historical Investigations at 41WT5 and 41WT6, Washington County, Texas. Reports of Investigations, No. 2. Center for Environmental Archaeology, Texas A\&M University, College Station.

Carpentier, D., and J. Rickard

2001 Slip Decoration in the Age of Industrialization. In Ceramics in America, edited by R. Hunter, pp. 115-134. Chipstone Foundation, Milwaukee.

Dismukes, D. C.

2003 Archeological Testing of 41BO185, A Possible Civil War Era Military Camp, West Columbia, Brazoria County, Texas. Archeology Studies Program, Environmental Affairs Division, Texas Department of Transportation.

Earls, A. C., T. L. Myers, B. S. Shaffer, K. W. Kibler, K. M. Gardner, L. S. Zimmerman, E. R. Prewitt, and S. L. Hannum 1996 Testing and Data Recovery at the Townsite of Old Velasco (41BO125), Brazoria County, Texas. Reports of Investigations, Number 64. Prewitt and Associates, Inc., Austin.

Earls, A. C., and M. S. F. Tomka

1994 Historic and Prehistoric Archeological Excavations at Varner-Hogg Plantation State Historical Park, Brazoria County, Texas. Texas Parks and Wildlife Department, Public Lands Division, Cultural Resources Program, Austin.

Few, J.

1999 Texas' Early Sugar Industry: A Comparative Study of Four Antebellum Sugar Mills in Brazoria County, Texas. Bulletin of the Texas Archeological Society 70:533-540.

Garner, F. H., and M. Archer

1972 English Delftware. Faber and Faber, London.

Greer, G. H.

1981 American Stonewares, the Art and Craft of Utilitarian Potters. Schiffer Publishing, Exton, Pennsylvania.

Hahn, T. H. G. III, R. B. Mahoney, T. M. Bond, C. Coxe, W. Coco, and J. Doucet

1994 Highway 61 Visited: Cultural Resources Survey and Testing of the LA-US 61 Four Lane Project Corridor between Bains and Thompson Creek, West Feliciana Parish, Louisiana. Prepared for the Louisiana Department of Transportation and Development. Draft report. Coastal Environments, Inc., Baton Rouge.

Hunter, R. R., and G. L. Miller

1994 English Shell-Edged Earthenware. The Magazine Antiques 145(3):432-444. 
Liebowitz, J.

1985 Yellow Ware: The Transitional Ceramic. Schiffer Publishing, Exton, Pennsylvania.

Lofstrom, E.

1976 A Seriation of Historic Ceramics in the Midwest, 1780-1870. Paper presented at the Joint Plains-Midwest Anthropological Conference.

McDavid, C.

1997 Descendants, Decision, and Power: The Public Interpretation of the Archaeology of the Levi Jordan Plantation. Historical Archaeology 31(3):114-131.

Majewski, M., and M. O’Brien

1987 The Use and Misuse of Nineteenth-Century English and American Ceramics in Archaeological Analysis. In Advances in Archaeological Method and Theory, vol. XI, edited by M. B. Schiffer, p. 163. Academic Press, New York.

Mahoney, R. B.

2003 41BO184 Site Assessment, Section 2 of the State Highway 35 between Angleton and West Columbia Corridor Improvement Project, Brazoria County, Texas. Manuscript on file Center for Archaeological Research, The University of Texas at San Antonio.

Mahoney, R. B., J. D. Weston, and D. D. Kuehn

2003 Archeological and Geoarcheological Survey of State Highway 35 between Angleton and Old Ocean, Brazoria County, Texas. Archaeological Survey Report, No. 320. Center for Archaeological Research, The University of Texas at San Antonio and Texas Department of Transportation, Environmental Affairs Division, Austin.

Miller, G. L.

1980 Classification and Economic Scaling of 19 $9^{\text {th }}$ Century Ceramics. Historical Archaeology 14:1-40.

1991 A Revised Set of CC Index Values for Classification and Economic Scaling of English Ceramics from 1787 to 1880. Historical Archaeology 25:1-25.

Moir, R. W.

1987 Refined Earthenwares and Rural Ceramic Traditions. In Historic Buildings, Material Culture, and People of the Prairie Margin, edited by D. H. Jurney and R. W. Moir, pp. 97-120. Richland Creek Technical Series, vol. 5. Institute for the Study of Earth and Man, Southern Methodist University, Dallas.

Noël Hume, I.

1970 A Guide to the Artifacts of Colonial North America. Knopf, New York.

1972 Historical Archaeology. Knopf, New York.

Pollan, S. D., W. S. Gross, A. C. Earls, J. T. Pollan, Jr., and J. L. Smith

1996 Nineteenth-Century Transfer-Printed Ceramics from the Townsite of Old Velasco (41BO125), Brazoria County, Texas: An Illustrated Catalogue. Prewitt and Associates, Inc., Austin.

South, S.

1972 Evolution and Horizon as Revealed in Ceramic Analysis in Historical Archaeology. Conference on Historic Site Archaeology Papers 6:71-116. 
Texas Historical Commission (THC)

2003a Texas Archeological Sites Atlas. <http://www.pedernales.thc.state.tx.us/> Accessed August 2003.

2003b Texas Historic Sites Atlas. < http://atlas.thc.state.tx.us/Atlas/atlas_search_frame.html $>$ Accessed August 2003.

United States Geological Survey (USGS)

1963 Angleton, Texas. 7.5 minute quadrangle map. Scale 1:24,000. Photo revised 1974. U.S. Geological Survey, Washington, D.C.

Yakubik, J.

1990 Ceramic Use in Late-Eighteenth-Century and Early-Nineteenth-Century Southeastern Louisiana. Unpublished Ph.D. dissertation, Department of Anthropology, Tulane University, New Orleans. 


\section{Appendix A \\ Historic Context Report, SH 35, Brazoria County, Texas}

Justin B. Edgington

HHM, Inc., 2003 


\title{
Appendix A: Historic Context Report, SH 35, Brazoria County, Texas
}

\author{
Justin B. Edgington \\ HHM, Inc.
}

\section{Introduction}

In March 2003, the Texas Department of Transportation (TxDOT) directed HHM, Inc. to conduct historical and archival research to aid cultural resource investigations along SH 35 in Brazoria County, Texas. The project area follows a mile-wide corridor along SH 35 between the Matagorda County line and SH 288 in Angleton, Texas. TxDOT tasked HHM with three objectives: 1) prepare a research design and preliminary assessment that examine both primary and secondary source material and consider how valuable these sources will be for the purpose of identifying potential locations of historic archeological sites along SH 35, as well as developing a historic context for Brazoria County; 2) identify potential locations of historic archeological sites within the project area based on the results of the archival research; and 3) develop a historic context for the project area that examines broad trends and patterns in local history and focuses on the development of the local plantation system and the establishment of freedmen's communities during the Reconstruction era. This report meets the requirements of the third objective by providing a historic context for the project area which examines historical trends, individuals, and events in Brazoria County before 1875. The report emphasizes the role of the local plantation system and the development of freedmen's communities in the years following the Civil War. In addition, the report documents the rise of the local petrochemical industry in the early twentieth century in relation to its potential effects on historic resources in the project area.

\section{Methodology}

The HHM project team for the SH 35 archival research project included David Moore, project supervisor, and Justin Edgington, historian. HHM staff conducted archival research for the project from March 7 through May 23, 2003, following initial consultation with TxDOT personnel in Austin. Archival research related to the preparation of a historic context occurred in both Austin and Angleton, Texas.

The HHM historian visited repositories in Austin including the Perry-Castañeda Library, General Land Office, the Center for American History at the University of Texas at Austin, and the Texas State Library and Archives. The research items collected at these repositories included diaries, deeds, letters, USGS maps, published primary accounts, agricultural, population, and slave schedules of the 1850 and 1860 censuses, and ad valorem records for individual plantation owners. In Angleton, the HHM historian visited the Brazoria County Courthouse, Engineer's Office, and Historical Museum. These repositories house deeds, plat maps, wills, transportation records, historic county maps, aerial photographs, and other historic material related to Brazoria County.

\section{Historic Context}

\section{Early Anglo-American Settlement of Brazoria County}

In an effort to stem the effects of hostile Indian tribes in Texas, the Spanish government in the early 1820 s actively encouraged Anglo-American settlers to colonize the vast region. In 1821, Moses Austin negotiated a permit with the Spanish to bring 300 Anglo-American families to Texas. His death shortly after, however, resulted in his son, Stephen F. Austin, taking over responsibility for the proposed colony. After negotiating changes to the permit related to Mexico's recent independence from Spain, Austin gathered 300 families and began the process of establishing the colony. According to the colonization agreement, each family was to receive a sitio (about 4,428 acres) and a labor (177 acres) of land. Austin selected the bottomlands of the Brazos, Colorado, and San Bernard rivers as the site for his colony. Many of the colonists selected sites facing the eastern bank of the Brazos River. Of the colonists who settled in what is present-day Brazoria County, most were born east of the Appalachian Mountains and brought with them the traditions and institutions of that region, including slavery (Kleiner 2003a).

One of the first settlers to arrive in Brazoria County was Josiah H. Bell, a planter from the Missouri Territory and Louisiana. Arriving at Washington-on-the-Brazos in 1821, Bell moved his family and slaves to present-day Brazoria County in 1823 . He established a large plantation at the site of his newly appointed league of land on the west side of the Brazos River. Bell quickly established himself as a prominent figure in the colony; Austin selected him to oversee the colony's affairs during Austin's visit to Mexico 
in 1822-23. Bell was also influential in the development of two important town sites in Brazoria County, Marion and Columbia (now East Columbia and West Columbia). The community of Marion, also referred to as Bell's Landing, became an important site for trade and commerce in the region. ${ }^{1}$

James Briton Bailey, a farmer born in North Carolina, settled in Brazoria County after living in Kentucky and Tennessee. Having purchased land from the Spanish government in 1818, Bailey was one of the few settlers living in Texas before the arrival of Austin's Colony. Bailey, his family, and six slaves established a small cotton farm on a large tract of land. Like many small farmers in the early years of settlement, Bailey faced a hostile environment. He went on to become an influential member of the region (Weir 2003).

By the middle of 1824 , the majority of the 300 families associated with the colony were in Texas. The region continued to attract eastern farmers eager to head west in search of cheap land and agricultural opportunities. By late 1825 , the colony counted 1,800 colonists. The colonists spread throughout Brazoria County and, in addition to Marion and Columbia, established the communities of Brazoria, Velasco, Quintana, and Liverpool.

\section{Brazoria County and Independence from Mexico}

The rapid growth of Brazoria County and the AngloAmerican settlement of Texas soon created difficulties with Mexican authorities. Relations between Mexico and AngloAmerican settlers remained tenuous, with both sides wary of the other. The Mexican government's direct attempts to maintain control over the affairs of Texas angered most settlers who desired a level of autonomy that would protect individual and property rights. In addition, most settlers retained the Southern morals, traditions, and practices of their origin, rather than accepting Mexican citizenship. Mexico, at the same time, began to fear the rapidly growing Anglo presence in the region. In fact, authorities feared that the presence of so many American settlers in Texas would cause the United States to eventually annex the region, a development Mexico was determined to prevent.

To stem American immigration to the region, in 1827 the Mexican government passed legislation prohibiting the future introduction of slaves into Texas. Texas settlers circumvented the law by classifying their slaves as indentured servants bound by contract. As a result, the growth of slavery in the state continued. Mexico took further steps in 1830 to assert control over Texas. A new law forbade further immigration from the United States, established the employment of Mexican troops in Texas, and called for customs duties on the economic activities of the settlers. Tensions increased, and in 1832 two skirmishes at Anahuac and Velasco demonstrated the rising anger of settlers against Mexican authority. Brazoria County, which in 1832 became its own municipality with Brazoria as its capitol, served as the political epicenter for much of the colony's growing insistence for independence from Mexico (Campbell 1989:26-30).

Despite a devastating flood, followed by a deadly cholera epidemic in 1833, Brazoria County continued to see an increase in white settlement and slavery. In 1834, the new president of Mexico, Santa Anna, began to exercise centralized control over the country, especially the region of Texas. Further skirmishes between the settlers and the Mexicans occurred in early 1835 as a result of the Mexican government collecting duties. By early summer, colonists became so convinced of the need for independence that they planned fall conventions in Brazoria County. Members of the conventions, including Brazoria County farmers Josiah Bell and John Sweeny, prepared for war with Mexico and began preparations for an army, a constitution and a declaration of independence (Campbell 1989:38-40).

Colonists meeting at Washington-on-the-Brazos declared independence from Mexico and wrote a constitution creating the Republic of Texas. However, news of the defeat at the Alamo and the massacre at Goliad quickly dampened their spirits. But a month later, Texas troops under the command of General Sam Houston ended their eastern retreat and surprised the Mexican army led by General Santa Anna at San Jacinto on April 21, 1836. Brazoria County played a crucial role in the victory by contributing much needed men and materials. The battle of San Jacinto established the independence of Texas from Mexico. Shortly after, Brazoria County hosted the Treaty of Velasco, which established peace terms and negotiated Mexico's formal recognition of the Republic of Texas. The selection of Columbia as the capital of the young republic verified Brazoria County's important political role during the war for independence (Campbell 1989:42-43).

\footnotetext{
1 "Josiah Bell," Vertical Files, Brazoria County Historical Museum, Angleton, Texas.
} 
By October 1836, the provisional government at Columbia began to take shape; Texans selected General Houston as President, and Stephen F. Austin and Henry Smith as Secretary of State and Treasury, respectively. The new congress carried on the business of the republic in two neighboring houses, with sheds as committee rooms. On December 20, 1836, the Congress of the Republic of Texas established Brazoria County as one of 23 counties. A year later, Columbia's brief tenure as the capital of the Republic of Texas came to an end, when congress selected the growing city of Houston as the new capital. ${ }^{2}$

\section{The Growth of Slavery in Brazoria County, 1824-1861}

Independence from Mexico allowed the settlers to actively pursue economic interests without threats against personal property. Nowhere was this issue more evident than with slavery. While not the main catalyst for the Texas Revolution, slavery undoubtedly fueled many of the colonists' complaints against Mexican rule. An examination of slavery's rapid growth during the antebellum period illustrates the institution's vital importance in Brazoria County's history.

As many of the early settlers came from the South and brought their slaves with them, the slave population in Texas in 1825 numbered 443, a small amount when compared with other southern states (Curlee 1932:5). Though the Mexican government officially discouraged the owning of slaves in Texas, they took no overt actions to prevent the practice mostly because conventional wisdom saw slavery as a necessary institution, especially in a region as unsettled as Texas. Many settlers arriving in Texas had worked large farms and plantations in the South, which required large labor supplies. As a result, the majority of them brought slaves with them. An absence of adequate labor coupled with an abundance of cheap, unimproved land in Texas, further encouraged this trend. In order to develop the land, settlers argued that slavery was vital; without slaves, the vast agricultural resources of Texas would remain largely untapped. Such views dictated the economic activities in Texas in the antebellum period (Campbell 1989:50-51).

By the start of the Texas Revolution, settlers had firmly established the use of slave labor in developing farms. When colonists gathered in Washington-on-the-Brazos in March 1836 to create a constitution, slavery was one of the issues addressed. They ensured the survival of the institution in the new republic as Section 9 of the 1836 constitution demonstrates:

\begin{abstract}
All persons of color who were slaves for life previous to their emigration to Texas, and who are now held in bondage, shall remain in the like state of servitude....Congress shall pass no laws to prohibit emigrants from bringing their slaves into the republic with them, and holding them by the same tenure by which such slaves were held in the United States.... No free person of African descent, either in whole or in part, shall be permitted to reside permanently in the republic, without the consent of congress [Campbell 1989:46-47].
\end{abstract}

They also included in the constitution a ban on the African slave trade. By that time most people viewed slave trading as morally indefensible; nevertheless, illicit African slave trading continued on a limited basis until the 1840s. The majority of slaves in Texas, however, continued to arrive with their owners through migration from Southern states. Brazoria County planters already established in the county could make arrangements to purchase additional slaves through slave dealers, the largest of which operated in Houston and Galveston. The dealers arranged the purchase of slaves from Georgia, Virginia, and other slave states and then made them available to Texas planters (Campbell 1989:52-53).

The number of slaves in Brazoria County grew steadily after Texas independence until the end of the Civil War (Table A-1). The United States annexation of Texas in 1846 caused

Table A-1. Slave Population in Brazoria County, 1837-1864

Sources: Campbell (1989) and the Eighth Census, Agricultural Schedule, 1860.

\begin{tabular}{|c|c|c|c|c|c|c|c|c|}
\hline Year & 1837 & 1840 & 1845 & 1846 & 1850 & 1855 & 1860 & 1864 \\
\hline $\begin{array}{c}\text { Number of Slaves in } \\
\text { Brazoria County }\end{array}$ & 892 & 1,665 & 2,094 & 2,520 & 3,161 & 4,292 & 5,110 & 5,125 \\
\hline
\end{tabular}

\footnotetext{
${ }^{2}$ Brazoria County Federation of Women's Clubs, "History of Brazoria County," (1940), p. 41.
} 
a dramatic jump in the number of slaves, as settlers from the United States began arriving in Texas in larger numbers. Like many slave holding regions across the South, Brazoria County saw a disproportionate increase in slaves versus white citizens. While Brazoria County's white population grew during the antebellum period, the slave population grew at an even faster pace. In 1847, the county's white population was 1,623 , while slaves numbered 3,013 , representing $65 \%$ of the population. By 1860 , that percentage was $71 \%$, with whites numbering 2,049 and blacks 5,110 (Few 1994:9).

The rapid growth of slavery in Brazoria County can be understood better when viewed in relation to slavery throughout the state. In the period that statistics for slavery exist, roughly 1837 to 1864 , Brazoria County ranked as one of the largest slave owning counties in Texas. Figures A-1 and A-2 illustrate this fact by showing the percentage of blacks in Brazoria County compared to the rest of the state's counties in 1840 and 1860.

As seen in Figures A-1 and A-2, Brazoria County was among several southeast counties with a high percentage of slaves. The large number of sugar and cotton plantations in the region explained the high concentration. In 1860, Brazoria County had the third highest number of slaves among Texas counties - only the counties of Washington and Rusk were higher. In addition, Brazoria County in 1860 included 10 of the 54 Texas slaveholders with 100 or more slaves. Of these ten, David G. Mills of Brazoria County was Texas' largest slaveholder with 344 slaves. $^{3}$

When compared to southern slaveholding states, Brazoria County exhibited unique characteristics regarding slavery. While the majority of southern states saw a decrease in the number of individuals owning slaves in the years leading up to the Civil War, Brazoria County slaveholders increased; in $1850,51 \%$ of the white population owned slaves, but in 1860 that number increased to $56 \%$. The value of slaves in Brazoria County was also higher than in other regions of the South as a result of the increased need for labor in Texas (Powers 1994:44).

Given that slavery had such an important role in the economic infrastructure of antebellum Texas, slave ownership often served as a mark of social status among planters in Brazoria County. Aside from land, slaves in large part represented the wealth of an individual. The number of slaves an individual owned determined his level of economic, political, and social success in antebellum Texas. Many of the top slaveholders in Brazoria County held powerful positions as bankers, lawyers, and state congressmen and were largely responsible for much of the wealth creation in the county. Though a minority, the wealthy planters of Brazoria County played a large part in determining the economic and political direction of the state before the Civil War (Wooster 1961:72).

\section{Agriculture and the Plantation Economy in Brazoria County, 1824-1861}

The explosive growth of both slavery and immigration were directly tied to the agricultural promise of Texas. Little else captured the attention of Texas' population after independence from Mexico and before the Civil War. Roughly $75 \%$ of Texas' white population was involved in agricultural pursuits in the antebellum period. From the initial settlement of Texas in the early 1820 s to 1861 , farmers throughout the state enjoyed a period of tremendous agricultural growth and diversity. The state benefited from a wealth of knowledge and became a "clearing house of Southern agriculture" (Curlee 1932:80).

The United States annexation of Texas in 1846 added to the agricultural vitality of the state. Settlers from the South moved to Texas in great numbers eager to buy cheap, fertile land and make their fortunes (Lowe and Campbell 1987:9). Popular magazines contributed to the excitement, as in this glowing 1851 passage from DeBow's Review:

No condition can be more independent and happy than that of the Texan farmer or planter. With a few weeks labor in the year, he can supply himself and family with all the necessaries and luxuries of life.... No country in North America holds out such inducements to emigrants as Texas, both for the salubrity of its climate, the fertility of its soil, and the variety of its products. ${ }^{4}$

Settlers who established farms in the coastal counties of Brazoria, Fort Bend, Wharton, and Matagorda found fertile soil and a long growing season. In Brazoria County, settlers such as Josiah Bell, James Britton, John Sweeny, and John $\mathrm{McNeel}$ developed early farms and were engaged in cotton

\footnotetext{
${ }^{3} 1860$ Census, Texas State Library and Archives, Austin, Texas.

4 “Texas," DeBow's Review (June 1851), p. 642.
} 


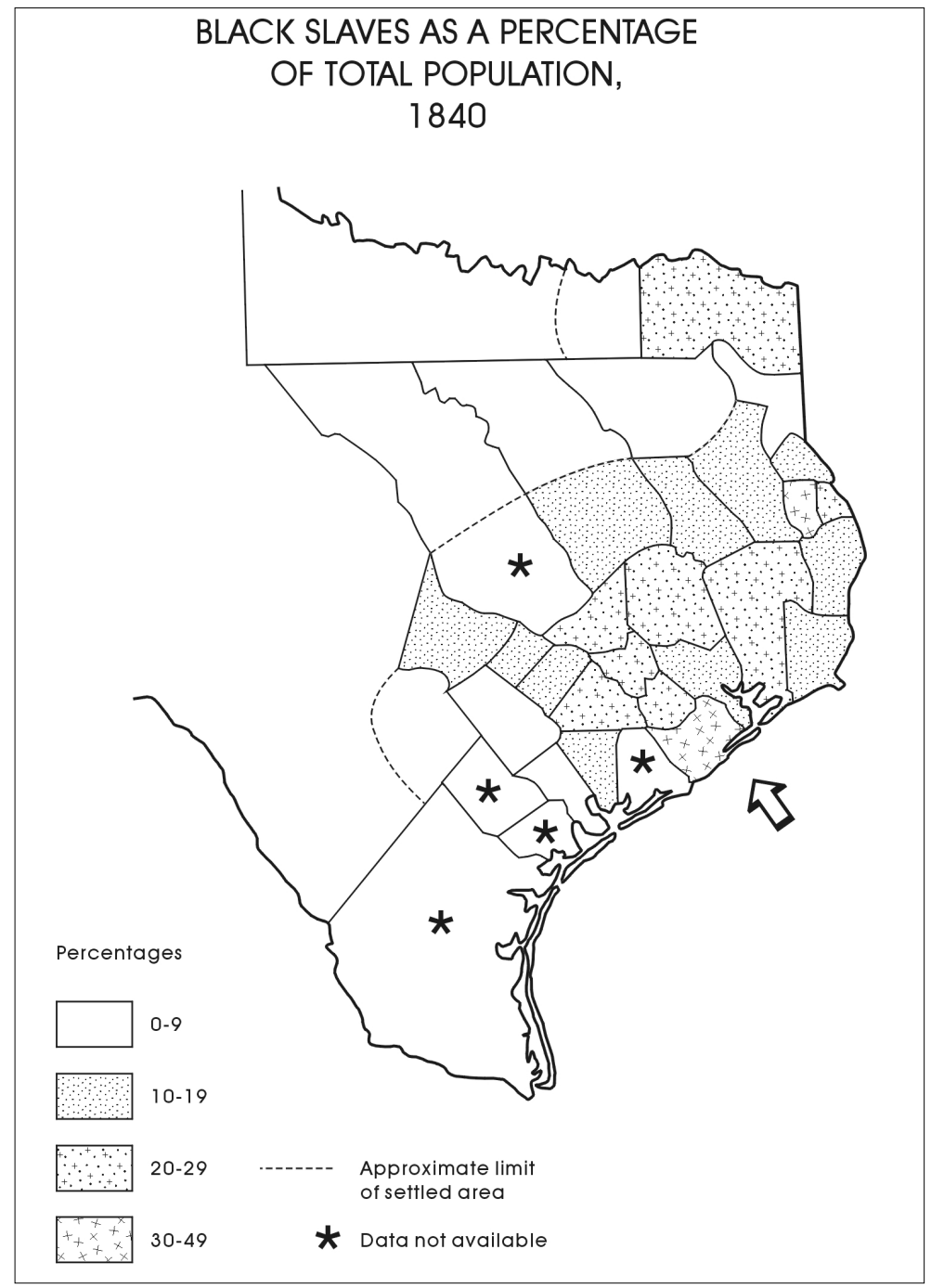

Figure A-1. Black slaves as a percentage of total population, 1840. Source: Tuffly et al. (1976); redrafted.

growing. Because land was inexpensive in Brazoria County, farmers often had more acres of unimproved land than they had in cultivation. Some had ten times more acres of unimproved land (Curlee 1932:74). As a result, slavery remained the most important factor in the success of a planter; without slaves in the field, land remained uncultivated.

The development of a plantation economy in Brazoria County grew quickly as early settlers gathered enough land and slaves to commit to cash crops like cotton and sugar. Historians have defined a plantation as a farm utilizing at least 20 slaves. Planters who owned plantations either managed the agricultural duties themselves, used a slave foreman, or in the case of many large plantations, hired an overseer to run the operation. Farmers with limited funds, who raised a small amount of cotton and other crops in order to meet basic expenses and needs, owned farms with fewer than 20 slaves. The ratio of planters to farmers in Brazoria County was unlike the rest of the South. With the historians' definition of plantation, $30 \%$ of Brazoria County's slaveholders were plantation owners, a percentage that was much higher than the $12 \%$ characteristic of the South (Powers 1994:54).

Rising cotton prices, long growing seasons, and inexpensive land helped planters thrive, build more elaborate homes and experiment with new crops such as sugar cane. Between 1850 and 1860, planters in Brazoria County established 63 


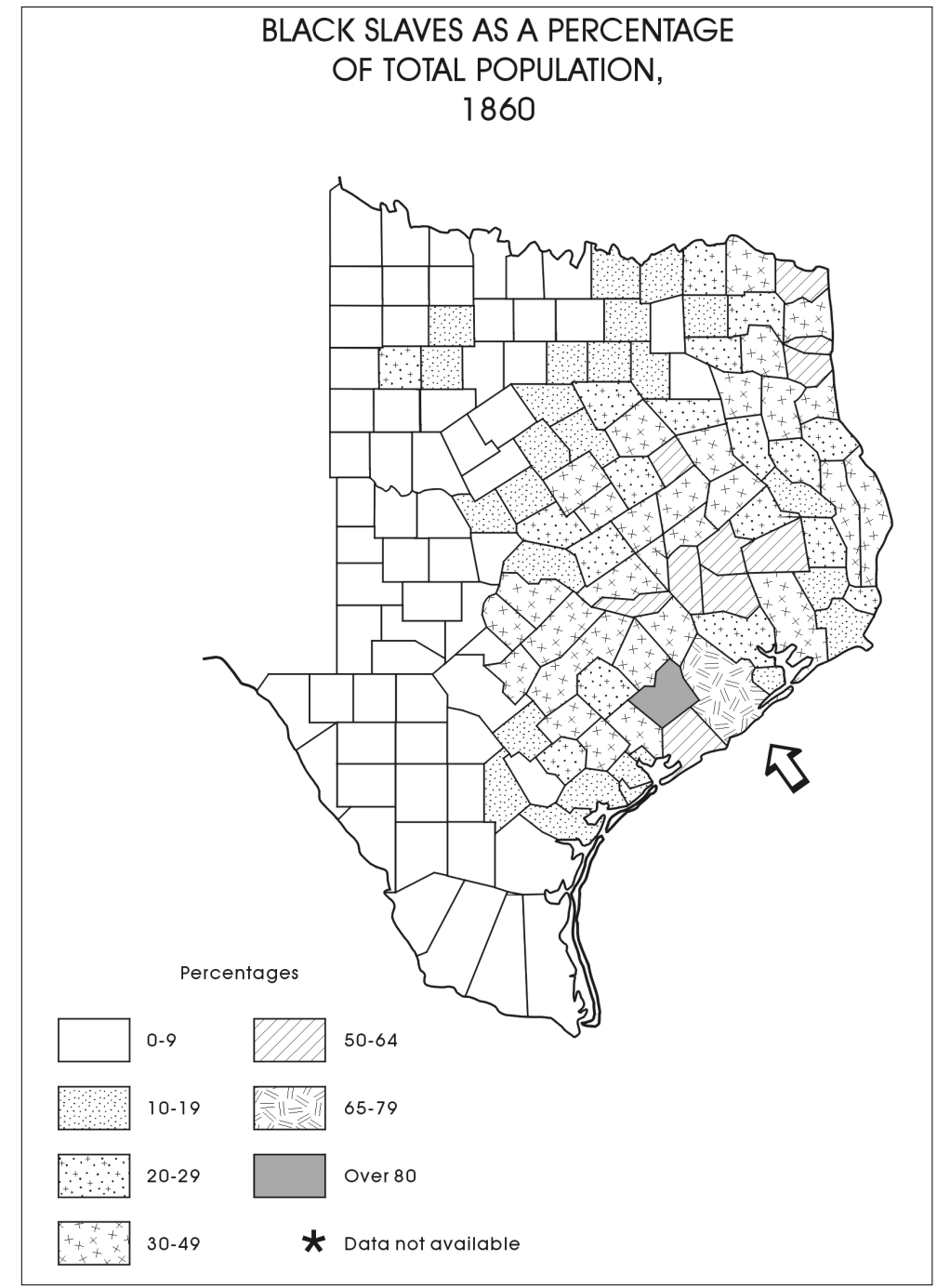

Figure A-2. Black slaves as a percentage of total population, 1860. Source: Tuffly et al. (1976); redrafted.

plantations and emerged as one of the wealthiest counties in the state. ${ }^{5}$ The 1860 agricultural census attested to the success of Brazoria County plantations by listing more than 37,465 acres of land in cultivation. The county led all Texas counties in total cash value of farms and plantations $(\$ 4,815,603)$, as well as cash value of farming implements and machinery $(\$ 531,717)$. The plantation economy bestowed great social, political, and economic power on the planter class and defined life in the county for decades.

\section{Cotton Farming in Brazoria County}

From the early settlement of Brazoria County to the Civil War, cotton played a major role in the rapid evolution of a plantation economy in the region. In Brazoria County, as in much of the antebellum South, the cultivation of cotton brought great wealth to planters with enough land and slaves for production. By the beginning of the Civil War, Texas had become the fifth largest cotton-producing state in the country. Table A-2 illustrates the rapid rise of cotton production in antebellum Texas.

The origins of cotton production in Brazoria County began during the initial organization of Moses and Stephen F. Austin's colony of settlers in the early $1820 \mathrm{~s}$. Both men knew the potential that cotton held for the region's future. Stephen F. Austin actively recruited settlers eager to grow

${ }^{5}$ The figure of 63 plantations was arrived at by calculating the number of slaveholders with 20 or more slaves. 
Table A-2. Cotton Crops in Texas, 1830-1860

Source: Texas Department of Agriculture (1909).

\begin{tabular}{|c|c|}
\hline Year & Total Cotton Crops in Bales \\
\hline $1830-1831$ & 335 \\
\hline $1834-1835$ & 3,084 \\
\hline $1839-1840$ & 6,970 \\
\hline $1844-1845$ & 25,879 \\
\hline $1849-1850$ & 58,072 \\
\hline $1854-1855$ & 125,427 \\
\hline $1859-1860$ & 431,463 \\
\hline
\end{tabular}

cotton and even claimed he would accept bales as payment for land. By 1822, early settlers in Brazoria County had planted the first cotton seeds in the region. The hot climate and rich soil of the county proved ideal for the growth of cotton and soon it emerged as the county's primary cash crop (White 1957:256). Statistics demonstrate that the county was among the top producers of cotton until the Civil War, with 3,531 bales produced in 1850 and 12,215 bales in 1860. Only six counties in Texas produced more cotton than Brazoria County in 1860 (Powers 1994:67).

The process of planting cotton in the county, like much of antebellum agriculture, was labor intensive. Planting began in late February in the warmer coastal climates like Brazoria County. Plows prepared fields for cultivation, and cottonseed from the previous year was planted. After a couple of weeks, the cotton seedlings would emerge and slaves would begin keeping seedlings free from weeds, a process that continued through the summer. The cotton plants began blooming in June and by August were ready for picking (Powers 1994:66-67). Planters faced multiple threats to their cotton crops ranging from inclement weather to pests and diseases. The lack of rain resulted in rust, but too much rain caused crops to rot. At varying stages of growth, the cut-worm, caterpillar, and army worm threatened cotton, and 1840$43,1846,1847$, and 1849 all saw damage from pests and disease (Curlee 1932:159-160).

Planters that avoided severe damage to their crops began the process of cotton picking in August. The average slave picked 150 to 200 pounds a day and worked dawn to dusk six or seven days a week. By the end of the year, most fields had been picked clean, although during some of the more productive years, cotton picking continued into January and February.

After picking came ginning, a process that cleaned and seeded cotton and then pressed it for export to larger markets.
Ever since the invention of the cotton gin in the late eighteenth century, cotton production had drastically increased. Cotton farmers arriving in Texas from the South in the 1820 s were eager to establish cotton gins alongside their cotton fields. Planter Jared E. Groce built the first gin in Austin's colony in 1825. Three years later, John McNeel, a cotton farmer from Kentucky, built one of the first cotton gins in Brazoria County. Noah Smithwick, a blacksmith, used steel from a shipwreck off the coast to construct the machine (White 1957:432-433).

By the 1840s, most of the larger planters owned cotton gins. For a fee, smaller cotton farmers often used the gins of larger planters to gin their cotton. Construction costs for the gins averaged $\$ 150$ and were either built by blacksmiths in the area or by gin manufacturing companies, such as those owned by Daniel Pratt, Robert Matthew, Manning and Arnett, and William Shield. Planters also used cotton presses, which pressed the ginned cotton into 400 or 450 pound bales. Gin houses usually housed cotton gins and presses and were located at least a half mile from any dwelling, fireplace, or chimney due to the danger of fire (Curlee 1932:167). Figure A-3 shows a typical Brazoria County gin house from the 1850s.

From start to finish, a single slave averaged about ten bales of cotton and an acre of land in Brazoria County yielded 2,000 to 4,000 pounds of seed cotton. After ginning, cleaning and pressing, cotton bales were then ready to be transported to cotton markets. For most planters in Brazoria County, the Brazos River provided a convenient and efficient mode of transportation for their cotton. Using rafts or steamboats, planters shipped the cotton bales to Galveston, where commission merchants or "factors" purchased the shipments. Merchants then stored the cotton and eventually sold it at a good price to cotton buyers. Profits, minus fees and commission, were then sent by the merchants to the planters in Brazoria County. Despite unfortunate years of drought, floods, pests, and disease, cotton production was lucrative for many planters and created much of the success of antebellum plantations in Brazoria County. With slavery providing free labor, planters reaped enormous profits from the production of cotton. As historian Abigail Curlee wrote, cotton:

administered to his [planter] love of power, paid his taxes; bought his coffee, sugar, and silver plate; clothed his family in substantial dignity and covered his slaves anew twice a year; and in fortunate years left him substantial balance with his factor in New Orleans, New York, or Galveston [Curlee 1932:174]. 


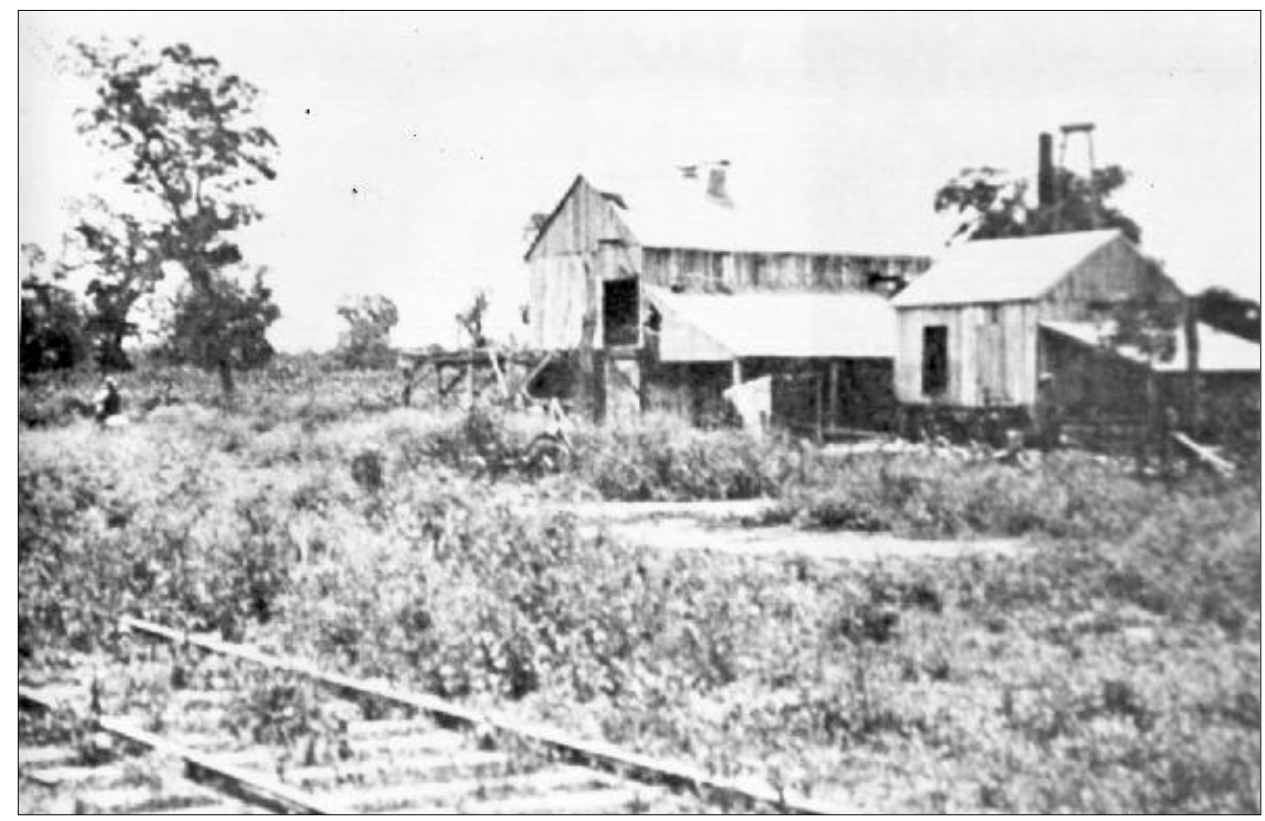

Figure A-3. Cotton gin on the Sweeny Plantation, Brazoria County, Texas, ca. 1870. Notice the close proximity of the cotton gin to the railroad.

Source: Brazoria County Historical Museum.

\section{Sugar Cane in Brazoria County}

While cotton was considered the major cash crop in Brazoria County and the rest of Texas, sugar cane eventually became synonymous with the growing plantations in Brazoria County. Though never threatening the vast markets of sugar grown in Louisiana, sugar cane cultivation in Texas established itself as an important component of economic life in the coastal region, especially in Brazoria County. By 1850, the four coastal counties of Brazoria, Fort Bend, Wharton, and Matagorda became known as the Texas Sugar Bowl because of the large amounts of sugar produced there.

Prior to sugar cane's introduction in Texas, the first appearance of the crop in America occurred in the mideighteenth century in Louisiana. In 1823, sugar planters there produced 30,000 hogsheads (a wooden container holding 63 to 140 gallons) of sugar a year. The success of sugar cultivation in Louisiana most likely convinced settlers heading to Texas of the crop's potential in the new region (Johnson 1961:9). In fact, both Moses and Stephen F. Austin thought that along with cotton, sugar cultivation could be successful in Texas. In fact, many colonists attempted to grow sugar. Visiting Texas in 1828, J. C. Clopper mentioned the early colonist attempts at sugar cultivation: ...there is more than one individual on this Mississippi of Texas, as the Brazos may be termed if small things may be compared with great, who will turn out more than 100 bales of cotton and sugar cane proportionally - it is thought there will be a sufficiency of sugar made this year to supply both Colonies-Austin's and Dewitt's...There are several planters already engaged in erecting sugar mills and they have resolved to dispose of it at 10 cts this is cheaper than it can be sold at here by purchasers and shippers from N. Orleans [Curlee 1932:174-175].

Also in 1828, Stephen F. Austin favorably reported the introduction of sugar in Texas: "...about six hundred bales of cotton and eighty hogsheads of sugar will be made this season" (Johnson 1961:11). As J. C. Clopper notes, colonists had begun erecting sugar mills in 1828 . William Stafford, an early colonist, built the first sugar mill in the colony in 1834 , but it was destroyed by the Mexican Army two years later. Stafford's early attempts at sugar production created a product that "was little more than partially crystallized molasses." Successive attempts and better cultivation techniques gradually resulted in a better product (Curlee 1932:176). 
One of the earliest planters of sugar cane in Brazoria County was John Sweeny, who arrived in Texas in 1832 with his family and a large contingent of slaves. Settling on the San Bernard River, Sweeny developed a large sugar plantation with the help of his sons and slaves. The Sweeny sugar mill used wooden rollers made out of native live oak trees. By 1844, Sweeny produced 100 hogsheads of superior sugar and over 100 barrels of molasses. One newspaper classified Sweeny's 1844 crop as comparable to and less expensive than Louisiana sugar (Johnson 1961:15). Further newspaper accounts described his success at raising seven successive sugar crops from the same roots, with no loss in quality. The ability of sugar cane to repeatedly propagate from an original cane source was called "rattooning." Brazoria County planters often explained that the Texas variety of cane rattooned at least six times, whereas Louisiana planters often had to replant each year (Curlee 1932:181-183).

Other early sugar planters in Brazoria County included Eli Mercer, Henry W. Munson and James P. Caldwell, all of whom established large sugar plantations along the Colorado and Brazos rivers. The emerging concentration of sugar planters in the coastal region, including Brazoria County, was due in large part to the area's extended growing season, a factor that allowed sugar cane enough time to mature for sugar production. These early planters experimented with two types of sugar cane: creole and ribbon cane. Heavily used by Louisiana planters, creole cane was the predominant type used; however, as early as 1828 , Texas planters learned from China about ribbon cane, which matured a month faster than other varieties. It was not until the introduction of steam power sugar mills, however, that planters began using ribbon cane, because the cane's tough fibers required grinding wheels to have stronger crushing power (Creighton 1986:197).

By the early 1840 s, several unrelated factors spurred the spread of sugar cultivation among planters in the county. Prior to this, cotton was the crop of choice for Texas farmers, especially given its easy cultivation and high profit margin. However, in 1840, a disastrous cotton worm infestation destroyed half of the region's cotton crops. A flood of rain in 1842 and 1843 further decimated cotton crops leaving many planters in the county worried about the reliability of cotton. To make conditions worse, prices for cotton were falling, planters faced cotton tariffs, and the panic of 1837 had destabilized Texas' paper currency. An article in the Brazos Courier in 1840 suggested a turn to sugar cultivation to offset the disappointments of cotton:
The few attempts [at sugar cultivation] which have been made in Texas have served to show that when the attempt is rightly made it will be crowned with signal success; and we doubt not that this, in a few years, will be found a very important item in the productions of this country. We desire earnestly to see a beginning made, and feel satisfied that the farmer will find this, at least as profitable a business as cotton planting, and much less mixt with uncertainties [Johnson 1961:13].

Recognizing these potential benefits of sugar cultivation, more and more planters made the shift to sugar. Others simply supplemented their cotton income with sugar production. In a few short years, sugar production in Brazoria County grew as a result of additional planters and an increased emphasis on the crop. One area in the coastal region saw a $23 \%$ increase in production in one year in the early 1840s (Curlee 1932:178).

Concurrent with the shift towards sugar cultivation were advances in sugar mill technology, which greatly improved production in the region. In fact, the evolution of sugar mills in Brazoria County paralleled the explosive growth of sugar in the region. In 1843, Captain William Duncan, who owned a plantation on Caney Creek, established the first steam powered sugar mill in Texas. The increased power from steam allowed Duncan to extract more cane juice more quickly than previous mills. Prior to steam, mills were powered by horses and used wooden rollers to crush the sugar cane.

The introduction of steam powered mills accelerated planters' investment in sugar. To house the new steam mills, planters built sugar houses of wood, and in some cases, brick. Sugar mills were often two stories in height and included space for the engine, the grinding rollers, juice vats as well as cooling areas for the final product. Waldeck Plantation in Brazoria County was one of the finest examples of sugar mills in the state and resembled a turreted castle with its three stacks (see Figure A-4). Construction of the Waldeck mill exceeded $\$ 50,000$ and included the most current sugar refining technology in 1849 (Creighton 1986:199-200). Figure A-5 shows drawings of a slave-constructed sugar mill from the 1840s in Brazoria County.

Planter investments in infrastructure at this time made clear the high overhead costs required of planters interested in entering the sugar business. As a result, after 1843, planters 


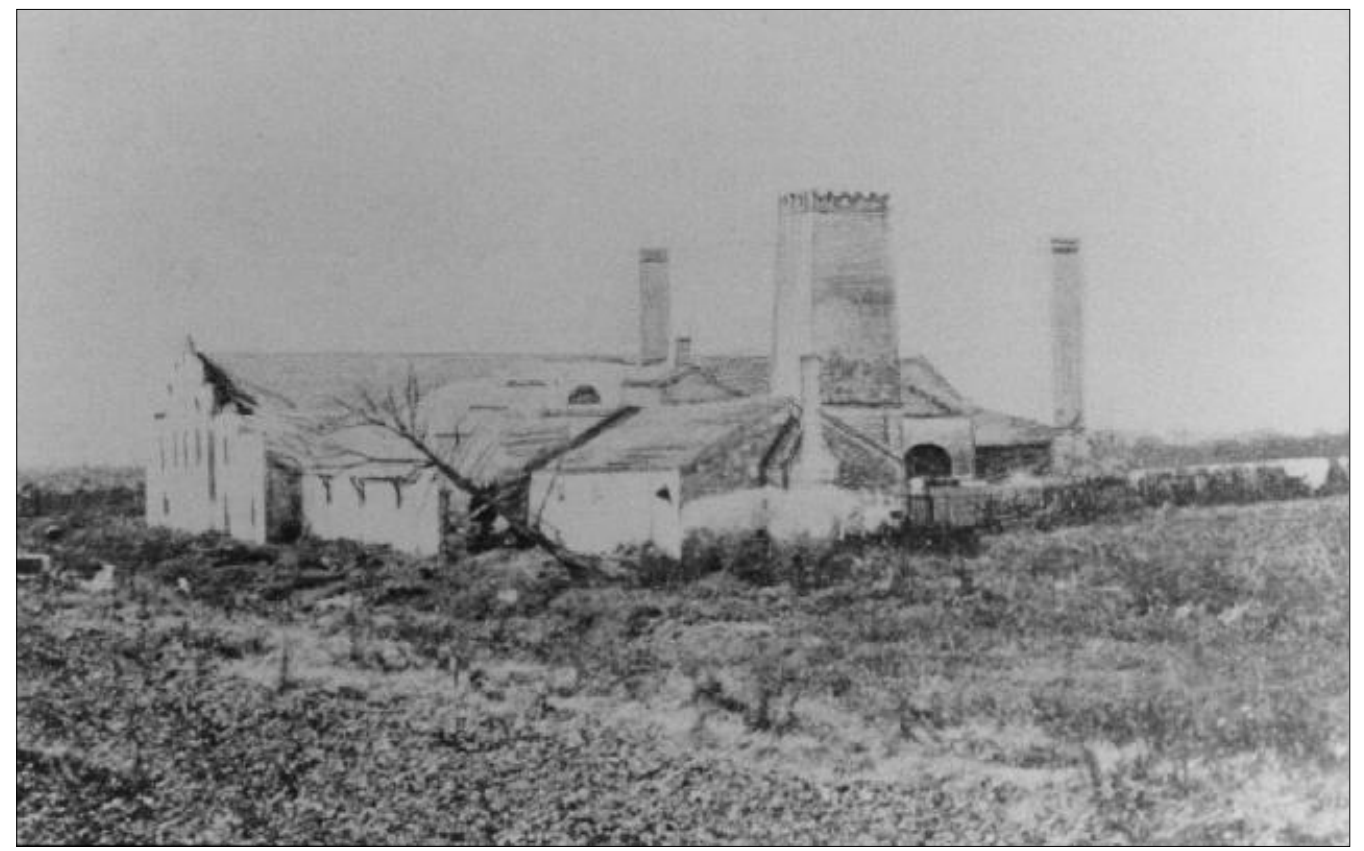

Figure A-4. Waldeck sugar mill at Waldeck Plantation, Brazoria County, Texas. Source: Brazoria County Historical Museum.

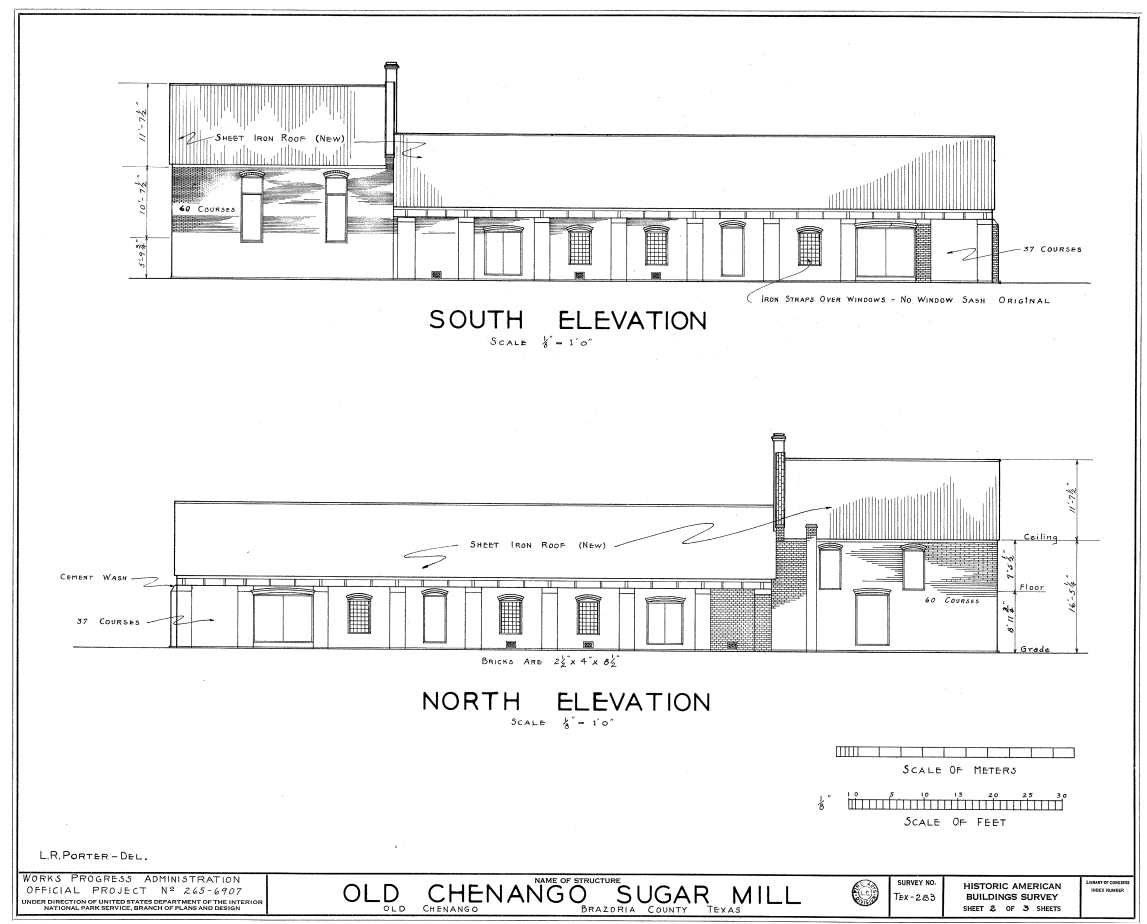

Figure A-5. Chenango Sugar Mill, Brazoria County, Texas. Source: Library of Congress. 
growing sugar were almost entirely wealthy men. New sugar houses ranged in cost from $\$ 5,000$ to $\$ 50,000$, with an average cost of $\$ 15,000$. In 1843 , the annual cost for a sugar planter was $\$ 50,000$ including 50 slaves and associated buildings. Agricultural censuses taken in 1850 and 1860 show Brazoria County planters making large investments in machinery - in most cases, the machinery was related to sugar production (Lowe and Campbell 1987:20).

In addition to the high costs of machinery, sugar cultivation required large numbers of slaves. Planting and processing sugar was a long and involved process, which began in January or February when slaves plowed fields into furrows. Slaves planted cane from the previous year's crop in the furrows and covered it with soil. When warm weather arrived, they removed a layer of soil to encourage the growth of the cane. As in cotton production, slaves periodically kept the crops free from weeds until the plants reached a mature height in late June. Slaves returned in October to cut the cane stalks, remove leaves and branches, and place the harvested cane on wagons on their way to the sugar house. The work of cutting cane in the fields was very difficult, and lasted from sunup to sundown, seven days a week (Lowe and Campbell 1987:20-21).

Once the cut cane reached the sugar house, slaves at the sugar mill worked an equally demanding schedule; planters required slaves to work round-the-clock shifts during processing months. The processing began with the placement of the cane into the steam-powered grinding rollers of the mill. With 150 pounds of steam pressure, the rollers crushed the cane until juices flowed into a large clarification vat made of copper or lead. Clarification removed impurities before the juice was moved to open kettles where further clarification and evaporation took place. The kettles, usually wrought iron, numbered four to six and were used to pass the cane juice through successive levels of processing. As seen in Figure A-6, French terms identified the kettles. As the cane juice moved from kettle to kettle, the volume of juice decreased and became purer. A furnace heated each kettle and removed additional impurities from the cane juice. As the concentrated juice reached the last kettle, it cooked until it was ready for the cooling process (Johnson 1961:24-25).

The sugar cane juice was then poured into cooling troughs, where after six to fourteen hours, it formed sugar crystals. Slaves placed granulated sugar in hogsheads and allowed it to drain for 20 to 30 days; the molasses that drained from the hogsheads was collected and then sold along with the unrefined sugar. The hogsheads of sugar were shipped to Houston or Galveston via steamship or railroad and then sold to buyers. A tremendous amount of effort was needed to produce one hogshead of sugar and two barrels of molasses; one estimate claimed that 1,300 pounds of raw sugar cane were needed to produce such an amount (Creighton 1986:201).

Because of the gradual shift to sugar and the adoption of steam-powered mills, the sugar output for Brazoria climbed in 1846, 1847, and 1848. In 1849, the Sugar Bowl region of Texas produced 7,351 hogsheads of sugar, a phenomenal number considering the relatively short period that sugar had been in Texas. Brazoria County stood alone as the highest producer of sugar that year, with 4,811 hogsheads. Production in 1850 and 1851 decreased somewhat due to a severe drought in 1850 . However, in 1852, Brazoria County and the rest of the sugar-growing counties of Texas produced the highest output of sugar before the start of the Civil War. A total of 11,023 hogsheads was produced, and Brazoria County led all counties once again with 8,202 hogsheads.

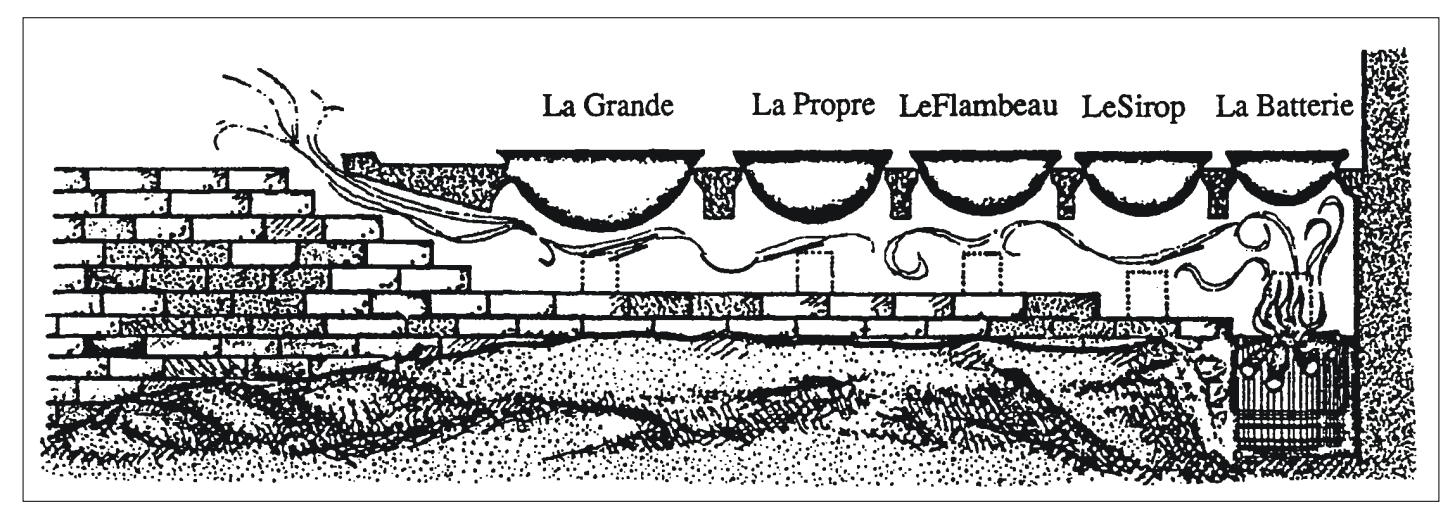

Figure A-6. Detail of sugar mill kettle system. Source: Few (1994). 
The crop that year was so successful that Louisiana listed it for the first time in their annual account of sugar production. Twenty-nine planters in Brazoria County were listed as having produced sugar that year - a sizeable increase from previous years. The county's investment in sugar production that year totaled $\$ 1,134,000$ in sugar houses, slaves, and land, a sum demonstrating the enormous wealth of planters in the region. Texas' output of sugar, however, never equaled Louisiana. In 1852, Louisiana produced 321,934 hogsheads compared to Texas' 11,023. Nonetheless, Brazoria County planters reaped enormous profit from the 1852 crops. Table A-3 lists some of the top sugar producers in Brazoria County for 1852 .

Though sugar production in Texas never exceeded the 11,023 hogsheads of sugar from 1852, the next three years produced respectable yields. A cold winter in 1856, however, proved that sugar was just as vulnerable as cotton to the extremes of Texas weather. Production for that year totaled 150 hogsheads, down from 8,977 the previous year. As a result, the trend of planters moving from cotton to sugar slowed considerably. Because machinery for sugar cultivation was so expensive, and lands suitable for production limited, the number of sugar planters decreased after 1856. A Galveston commercial publication that year reached the same conclusions of many planters in the region when it claimed that "the present year closes an epoch in the growth of sugar in Texas." Subsequent years saw a larger increase in production, but still considerably lower than 1852. The beginning of the Civil War in 1861 interrupted production and signaled the end of plantation driven sugar production in Brazoria County. Though the industry resurfaced after the war, it bore little resemblance to the highly prosperous plantation system in the antebellum period (Curlee 1932:191-197).

\section{Corn Production in Brazoria County}

Though cotton and sugar provided Brazoria County planters with pure profit, the production of corn sustained plantation life throughout the state. Requiring little expense or labor to grow, corn provided a consistent supply of food for planters and slaves, as well as cattle, horses, mules and other plantation animals. An 1853 article in DeBow's Review stated that corn production in Texas was an important agricultural advantage for planters:

The land here is unrivaled in the production of corn by any southern soil-from forty to sixty bushels to the acre being an ordinary yield - enabling the planter, with little trouble, to supply himself with this indispensable article at no cost. ${ }^{6}$

Table A-3. Production of Sugar in Brazoria County, Texas, 1852

Source: Champomier (1852/53).

\begin{tabular}{|l|c|}
\hline Planter (Brazoria Countv) & Number of Hogsheads \\
\hline R. \& D.G. Mills (Bynum Place) & 558 \\
\hline Charles D. Sayre & 200 \\
\hline William Manor & 200 \\
\hline Col. Morgan L. Smith & 520 \\
\hline C.R. Patton & 210 \\
\hline R \& D.G. Mills (Lowood Place) & 780 \\
\hline James P. Caldwell & 200 \\
\hline A.F. Westall & 285 \\
\hline James Perry & 260 \\
\hline James G. McNeel & 408 \\
\hline Sarah Mims & 368 \\
\hline Gen. James Hamilton & 450 \\
\hline Maj. A. Jackson & 296 \\
\hline Col. W. Sharp & 500 \\
\hline Hal. G. Runnels & 270 \\
\hline
\end{tabular}

6 “Texas-Climate, Rivers, Lands, Productions, Animals, Minerals, Population, Government, Emigration,” Debow's Review 1853, (Vol. III), p. 642. 
Planters valued corn production as necessary protection against the uncertainties that could decimate cash crops like cotton or sugar. Thus, planters almost always created space in their fields for corn production. Yields in Brazoria County averaged 40 to 80 bushels, which planters stored in corn cribs and saved for livestock feed or ground into cornmeal for corn bread and hominy. They used several methods to grind corn, including horse or hand mills, with grist mills appearing in the county after the late $1820 \mathrm{~s}$. The amount of corn grown in Texas from 1829 to 1860 demonstrates the value corn held in the plantation economy (see Table A-4). Statistics for Brazoria County's corn production were only available for 1860 , when the yield was 299,820 bushels (Curlee 1932:201-202).

Table A-4. Cotton production in Texas Source: Curlee (1932).

\begin{tabular}{|c|c|}
\hline Year & Bushels of Corn \\
\hline 1829 & 150,000 \\
\hline 1850 & $5,978,590$ \\
\hline 1860 & $16,500,702$ \\
\hline
\end{tabular}

\section{Other Crops and Livestock in Brazoria County} Brazoria County plantations supplemented their diets with a variety of vegetables and livestock. Aside from corn, planters grew a steady supply of sweet potatoes, Irish potatoes, and peas. One of the larger plantation owners, David G. Mills, raised a total of 25,000 bushels of corn, 9,000 bushels of sweet potatoes, and 250 bushels of field peas in 1850 in order to feed his large slave force. Some planters grew elaborate fruit orchards often with seeds brought from southern states. ${ }^{7}$

Livestock represented an important part of the plantation system by providing necessary sustenance for slaves and families alike. Hogs roamed wild until a few weeks before slaughtering time, when they grew fat on corn. Planters preserved meat for use throughout the year and rationed it out to slaves as part of their daily meals. Cattle also provided necessary meat for planters in Brazoria County. In the years leading up to the Civil War, stock raising became an increasingly important activity for many planters. In 1860, Brazoria County included 66,000 cattle, making it one of the top ten cattle producers in the state; the total cash value was nearly $\$ 1,000,000$. One Brazoria cotton planter, Mordello S. Munson, owned 86 cattle in 1850 . Ten years later, he had increased that to $300 .{ }^{8}$ The Munson family continued to raise cattle after the Civil War and represented some the wealthiest cattle ranchers in postbellum Brazoria County. The early success of stock raising in the county thus signaled the rise of the cattle industry, which after the Civil War emerged as a more integral component of the county's agriculture (Powers 1994:79).

\section{Brazoria County Plantations}

By 1860 , Brazoria County was home to 63 plantations (given the definition of 20 slaves or more) some of which grew cotton or sugar exclusively, while many cultivated both. Since Brazoria County plantation owners were among the wealthiest individuals in the state, they owned some of the grandest plantations in Texas. The majority arrived in Texas from the old southern plantation states, bringing with them "inherited attitudes, customs, and methods" (Curlee 1932:iv). As a result, plantations in the county incorporated many traditional southern elements. Nevertheless, the unique characteristics of life in Texas, such as limited transportation, high soil fertility, and a long growing season, shaped the development of plantations in the state.

To better understand the characteristics of plantations in Brazoria County, three plantations-Bynum Place, Willow Glen, and Ridgeley Plantation — will be examined.

\section{Bynum Place}

Located in what is today known as Bailey's Prairie, Bynum Place was owned by David G. and Robert Mills, two brothers who played an important social and economic role in Brazoria County. Moving from Tennessee to Texas in 1832, the Mills brothers joined their brother Andrew in a merchandising business. After Texas gained independence, the Mills brothers quickly became important in the young economy of the republic. In 1849, their merchandising firm moved to Galveston, where it became one of the leading exporters of Texas cotton and sugar. Both quickly became wealthy and were worth between $\$ 3$ and $\$ 5$ million by 1860 . While Robert ran the firm in Galveston, David operated three plantations in Brazoria County - Low Wood, Palo Alto, and Bynum Place. By 1860, David Mills oversaw 200,000 acres of Texas land, with 3,300 in cultivation. In 1844, the three plantations produced 600 bales of cotton, the highest in the state at that time. Sugar production on the Mills' plantations also exceeded all others in 1852 (Harris 2003).

\footnotetext{
${ }^{7} 1850$ Agricultural Census, Texas State Library and Archives, Austin, Texas.

${ }^{8}$ 1850, 1860 Agricultural Census, Texas State Library and Archives, Austin, Texas.
} 
According to the 1850 and 1860 agricultural census for Texas, Bynum Place had 850 acres in cultivation and 3,200 acres of uncultivated land. In 1850, Bynum Place contributed 656 hogsheads of sugar, its highest output in the antebellum period. ${ }^{9}$ In addition to sugar, the plantation grew corn, Irish potatoes, and sweet potatoes. Livestock included hogs, horses, cattle, mules, oxen, and milk cows. Farming implements and machinery in 1850 were valued at $\$ 15,000$, which included a brick sugar mill on the plantation grounds. In addition to the mill, outbuildings were constructed of bricks made by slaves (Strobel 1930:10).

David Mills depended upon a large slave force to operate his plantations. In 1850, the three plantations included a total of 344 slaves. By 1860, Bynum Place alone used 120 slaves housed in thirty slave cabins. Among Brazoria County's plantations, the Mills brothers operations were among the largest and wealthiest. ${ }^{10}$

\section{Willow Glen Plantation}

The land associated with Willow Glen Plantation was originally part of James Brit Bailey's league. In 1832, Bailey sold a half league of land to Charles D. Sayre, a trader from New York who came to Texas in 1831. In 1835, Sayre built a cotton gin, processing 100 bales of cotton that year. During the period of Texas independence, Sayre was actively involved, serving in the militia, as well as supporting the movement financially. In 1840, Sayre owned 24 slaves most of whom were actively involved in processing sugar cane (Roell 2003). Like many Brazoria County planters at the time, Sayre moved from cotton to sugar cultivation due to its profitability and suitability to the region. Sayre erected a sugar mill located on the nearby Josiah Bell plantation in East Columbia. James Henry Dance, who built numerous mills across the county, built the mill (Creighton 1986:199).

In addition to the sugar mill, Sayre and his wife constructed a two-story frame residence, slave cabins, a smokehouse, barns, stables, and other outbuildings. A public road marked the plantation's southern border. The 1850 agricultural census shows Sayre with 300 acres in cultivation and the cash value of the farm totaling $\$ 9,000$. The value of Sayre's farming implements was $\$ 20,000$, demonstrating that he had invested heavily in the equipment need for sugar production. ${ }^{11}$ Sayre was one of the top twenty producers of sugar in the county. In 1850 , he produced 160 hogsheads of sugar; by 1852 , that number had increased to 200 hogsheads. Sayre died in 1856, and the plantation was sold to James Campbell who continued to grow sugar. Figure A-7 shows a 1914 plat map of the Willow Glen plantation, which by that time retained little if any of its original physical features.

\section{Ridgeley Plantation}

In 1850, Mordello S. Munson and his new wife settled on 1,000 acres of land he received from his mother and stepfather and established Ridgeley Plantation. Deed records described the tract as "containing 1,000 acres being the west end of the tract of 2,479 acres situated on the east bank of the Brazos River in the county and purchased from the said William J. Bryan." The land was located in the western portion of the Cornelius Smith league (Williamson 1987:307).

Upon arrival in 1850, M. S. Munson and his wife, Sarah, lived in a small house known as "Hard Castle." Later that year, Munson began to expand his farmstead by purchasing 300 adjoining acres to the west. Additional land purchases increased Munson's plantation to 1,500 acres by 1859 . Owning eight slaves in 1850, Munson began planting cotton, corn, and vegetables, and raising livestock. Munson operated his land as a cotton plantation, and sold the product to brokers in Columbia and Brazoria.

The 1850 agricultural census listed Munson with 110 acres in cultivation and $\$ 600$ dollars worth of farming implements (cotton press, cotton gin, etc.). Munson produced 19 bales (400 lb. each) of ginned cotton and raised 200 swine and 86 livestock. The cash value of Munson's farm was $\$ 2,200$, with livestock adding another $\$ 1,512 .{ }^{12}$

In 1855, Munson and his wife built a new home a short distance from their first house. Four bedrooms in size, the plantation house, named Ridgeley, included a living room, dining room, and a long porch in the front (Figures A-8 and A-9). In addition to the main residence, there was a separate kitchen approximately 20 feet from the house, an office, a blacksmith shop, smokehouse, barns, stables, and slave quarters. All buildings at Ridgeley Plantation were made of wood, while cisterns, chimneys, and walkways were constructed of bricks manufactured by the slaves. ${ }^{13}$

${ }^{9} 1850$ Census, Texas State Library and Archives, Austin, Texas.

${ }_{10} 1850$, 1860 Slave Schedule, Texas State Library and Archives, Austin, Texas.

${ }^{11} 1850$ Agricultural Census, Texas State Library and Archives, Austin, Texas.

121850 Agricultural Census, Texas State Library and Archives, Austin, Texas.

13 "Plantations," Vertical Files, Brazoria County Historical Museum. 


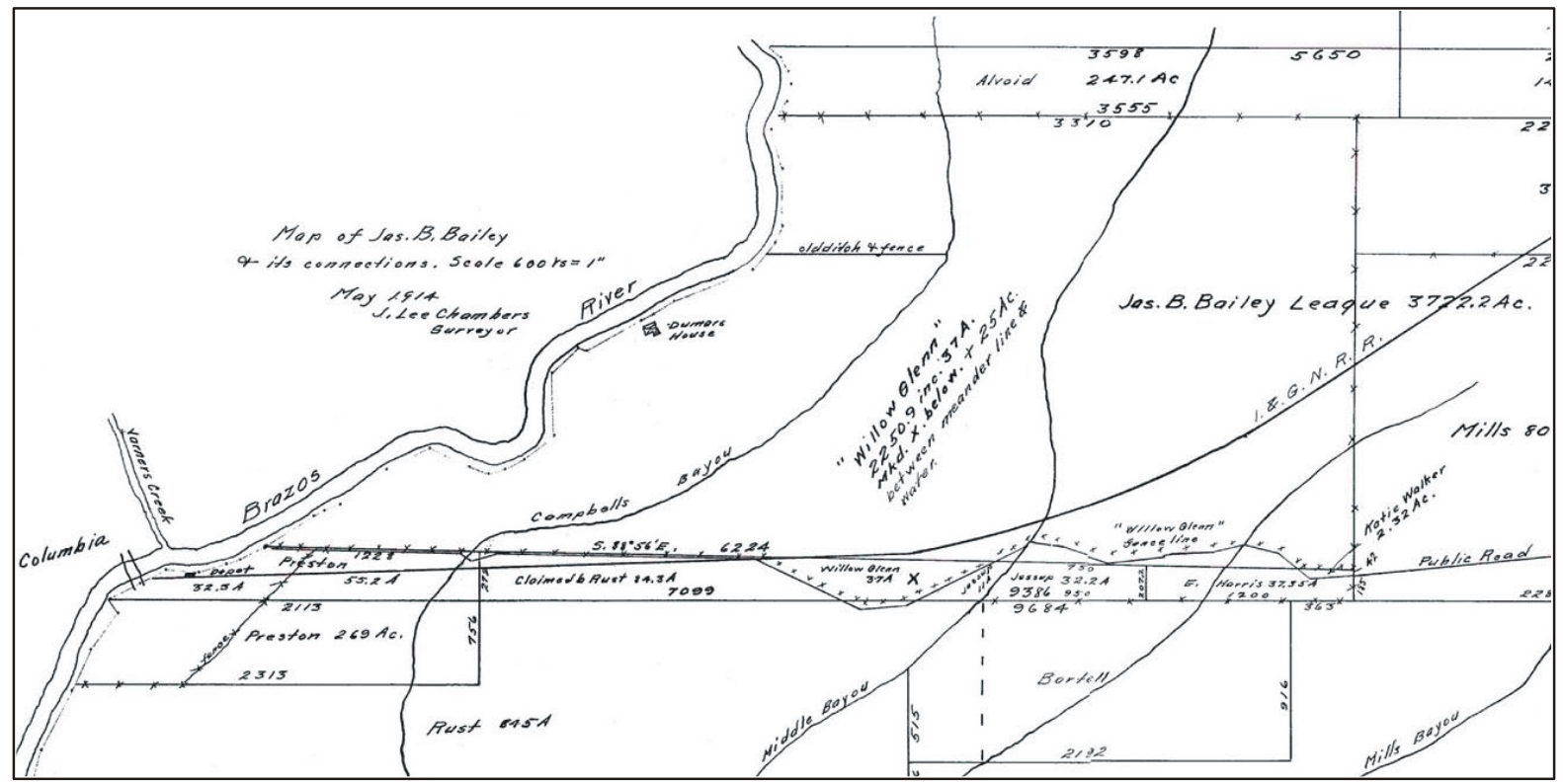

Figure A-7. 1914 plat map showing the location of Willow Glen Plantation. Source: Brazoria County Historical Museum.

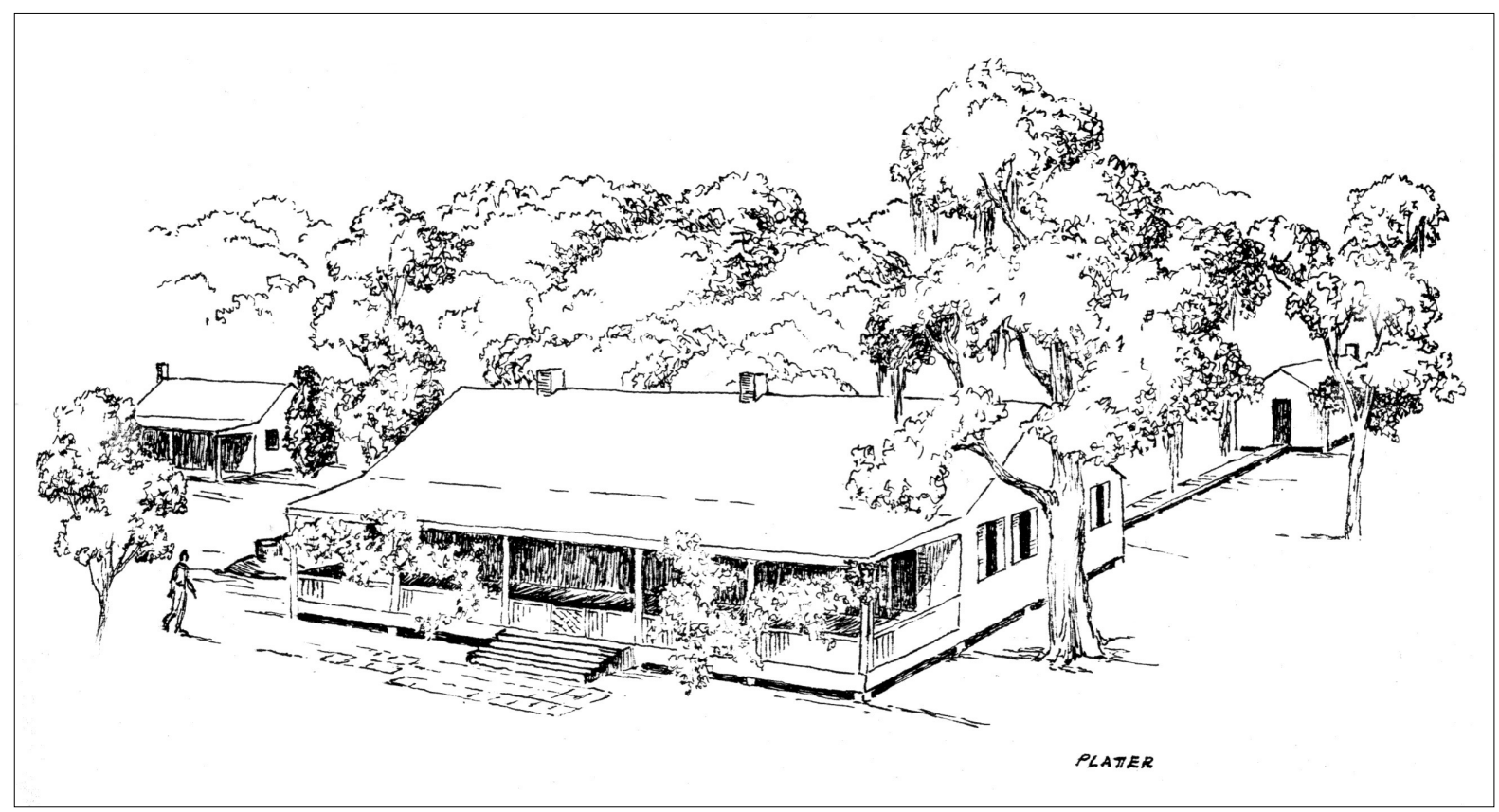

Figure A-8. Drawing of the main residence at Ridgeley Plantation. Source: Platter (1961). 


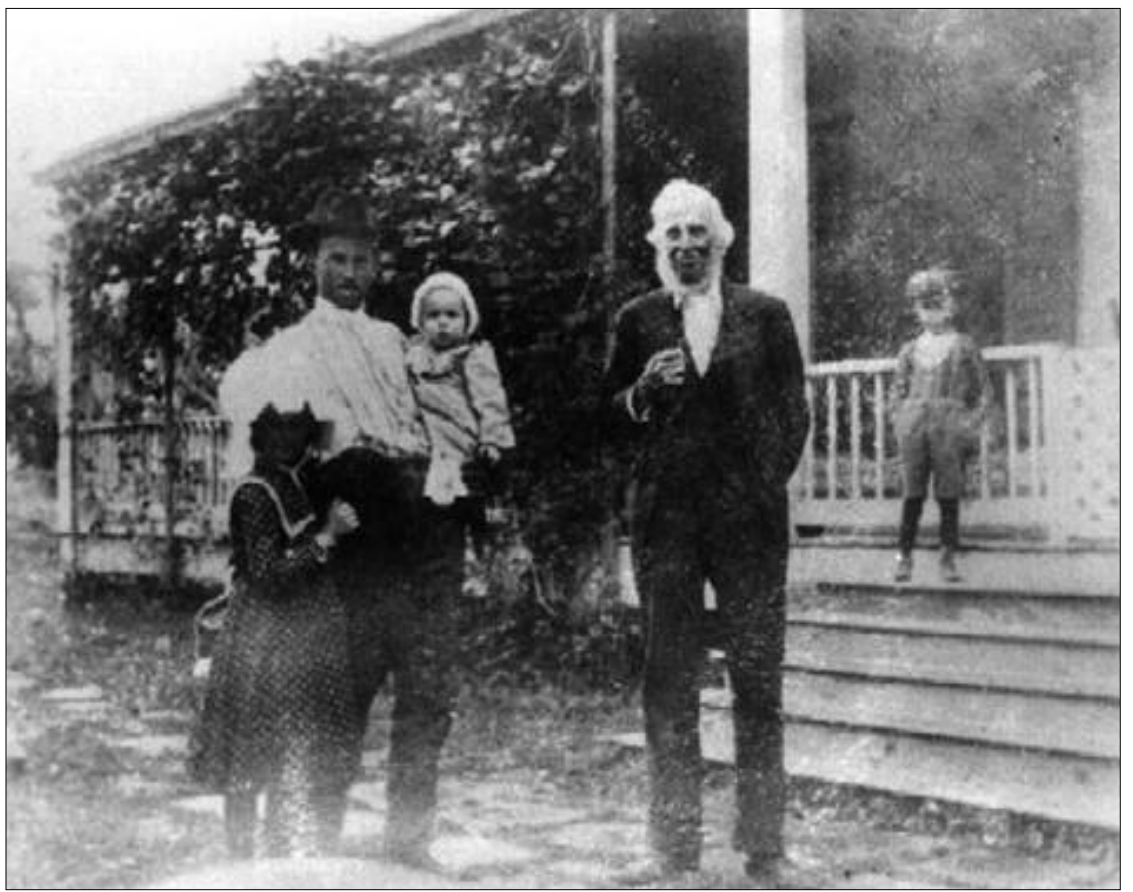

Figure A-9. M. S. Munson (right) at Ridgeley Plantation.

Source: Brazoria County Historical Museum.

In addition to running his plantation, Munson managed a law practice with offices in Brazoria, Houston, and Galveston. His rising prominence in the community coincided with an increase in his plantation's operations. By 1860 , Munson had increased the area of cultivation to 160 acres bringing the total cash value of his farm to $\$ 20,000$. Munson continued to rely on livestock as a major source of revenue; in 1860 , he owned 300 cattle worth $\$ 5,785$. The plantation also included 50 horses, a sign of wealth within the plantation culture. Cotton production increased as well ( 60 bales), and was aided by the construction of a cotton gin, located in a field referred to as the "gin house field." Munson also grew tobacco, wheat, and potatoes. ${ }^{14}$

As he was often away on business, Munson assigned a slave, Ralph, the duty of overseeing the farming and ranching activities of the plantation. The 1860 slave census listed Munson as owning 28 slaves housed in five slave quarters. In the beginning, the Munsons constructed their slave quarters near their house, since slaves helped Sarah Munson with cooking, making clothes, and washing and ironing. As the plantation grew and more fields came under cultivation, they built slave quarters closer to work areas (Murray 1940).
In addition to owning a plantation and his law practice, Munson in 1857 served as a state representative in Austin. In 1861, Munson left the plantation to serve the Confederacy; during his absence, management of the plantation was assumed by Sarah Munson. Ridgeley Plantation represents the numerous small plantations that operated in Brazoria County, many of which only grew cotton because of the cheaper production costs.

Aside from these three representative plantations, the county included sugar and cotton plantations of varying wealth and size including Lake Jackson, China Grove, Chenango, Peach Point, and Waverly.

\section{Transportation and the Plantation Economy}

A key factor in the development of plantations in Brazoria County was its favorable access to markets. Early settlers located their homesteads near rivers and creeks knowing that water would be important to their commercial success. As a result, plantations in the county developed primarily

${ }^{14} 1860$ Agricultural Census, Texas State Library and Archives, Austin, Texas. 
along the Brazos and the San Bernard rivers, with large clusters along the Brazos River in the southern portion of the county. Figure A-10 shows a plat map that illustrates how important rivers were to the siting of individual buildings. The map shows a sugar house, main dwelling, and an outbuilding situated alongside Oyster Creek.

As cotton and sugar cane crops expanded, rivers and creeks increasingly served plantation owners, as rafts, and later steamboats, were used to ship bales of cotton or hogsheads of sugar south to the merchants of Galveston. The Brazos River in particular emerged as the central route for the county's growing immigration, commerce, and communication needs. Boats penetrated as far inland as East Columbia, which became an important commercial site for planters; Brazoria and Velasco, situated along the Brazos, developed customhouses as a result of the growing commercial traffic. By 1840, Houston was attracting business away from the Brazos, prompting county leaders to expand transportation infrastructure. Finally, in 1857, a canal connecting the Brazos River to Galveston Bay was completed, greatly aiding the flow of commercial goods (Kleiner 2003a).

In addition to rivers, roads were an important component of plantation life. Many roads developed according to the location of existing plantations, with some planters building roads connecting neighboring plantations. Existing plat maps often show public roads in some way bordering or intersecting plantation sites as seen in Figure A-11. An important source for communication, roads also enabled planters to travel in order to buy supplies or attend important business or political matters.

The county's growing wealth and the poor condition of many roads prompted leaders to pursue the construction of a railroad. Earlier attempts beginning in 1836 all failed, until 1856, when Brazoria County planters united with Houston

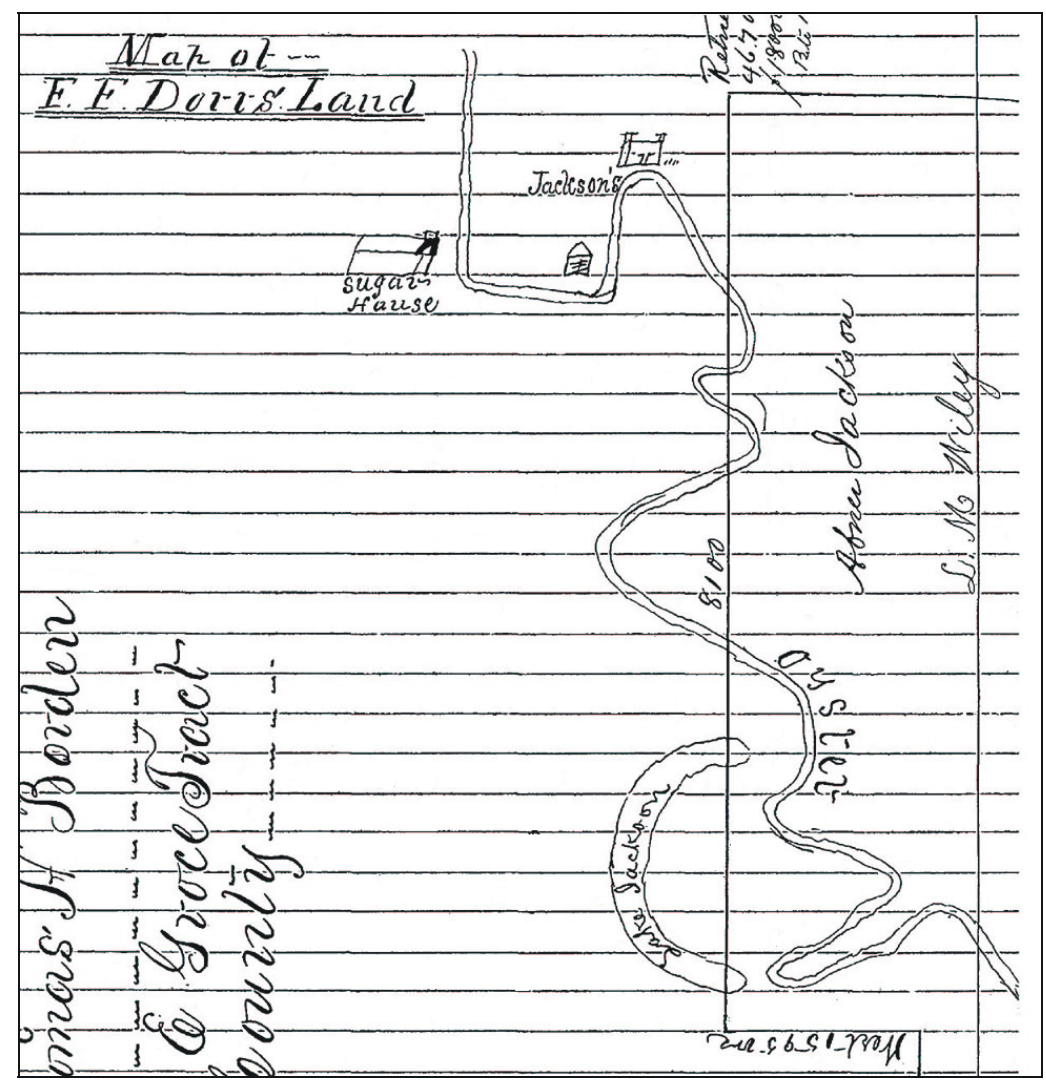

Figure A-10. Plat map showing Abner Jackson's plantation with sugar house, residence and outbuilding flanking Oyster Creek.

Source: Brazoria County Courthouse. 


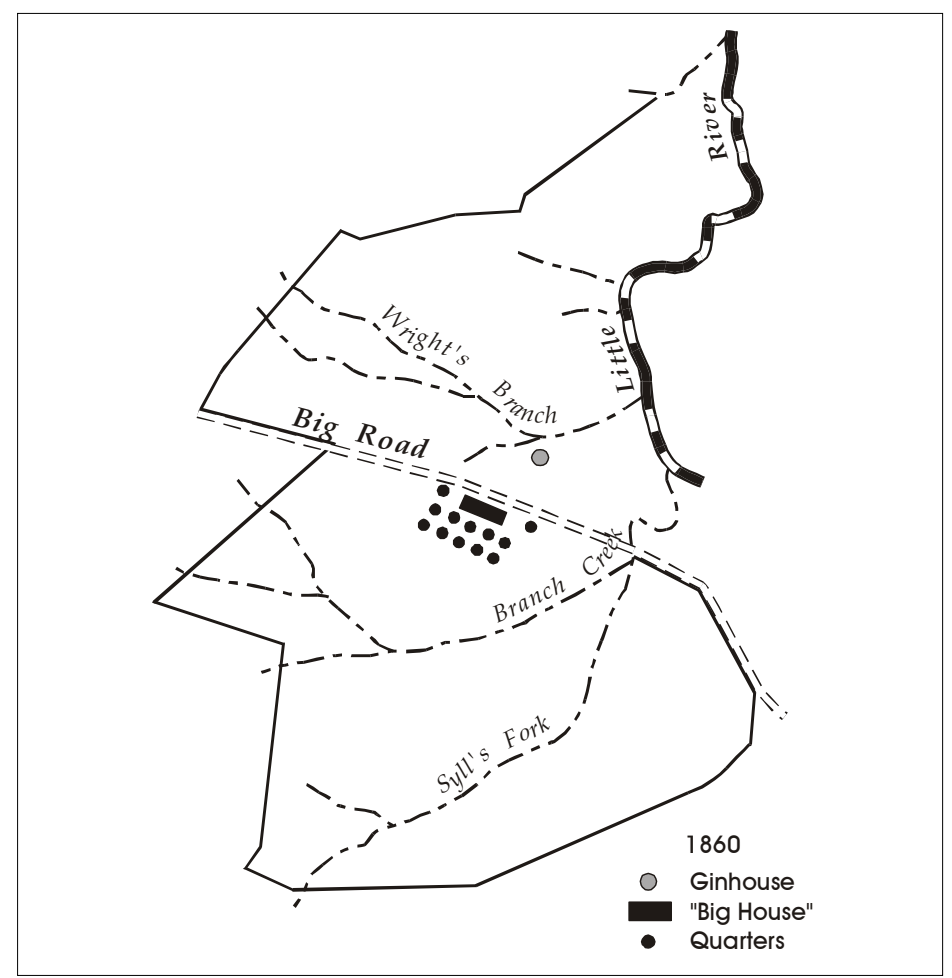

Figure A-11. Map showing a public road adjacent to a ginhouse, residence, and slave quarters. Source: Iruegas (2003); redrafted.

merchants to charter the Houston Tap and Brazoria Railway Company. Known as the "Sugar Road" because it transported the county's commercial crops to the markets of Houston, the Houston Tap and Brazoria was completed by 1859 and connected Columbia with Houston. The use of slaves kept construction costs relatively low. Figure A-7 shows the Houston Tap and Brazoria (shown as the International and Great Northern Railroad) on the southern border of the Willow Glen plantation. The railroad was heavily used until the outbreak of the Civil War, when the tracks were used to make revolvers (Creighton 1986: 213-215).

\section{Plantation Landscapes and Layouts}

As discussed previously, Brazoria County plantations often followed southern customs. Planters arranged their operations according to the wealth of knowledge they brought from southern states. With some exceptions, the outbuildings, main residences, slave cabins and fields of Brazoria County shared characteristics with those in Virginia, Tennessee, Louisiana, and other southern states. The architectural historian John Michael Vlach, however, notes that a range of factors created a variety of plantation landscapes. After looking at plantations across the South, he argues, "that it is more correct to speak of southern plantations rather than of the southern plantation" (Vlach 1993:193).

Nevertheless, certain overall trends in plantation design were evident: sugar estates were "largely industrial in character, whereas cotton plantations often resembled nothing more than oversized farms" (Vlach 1993:193). In other words, landscapes usually reflected the type of work performed; cotton plantations involved much less expensive equipment and smaller labor requirements than sugar, and as a result, the landscapes were simpler and less organized.

Most plantations included common elements like a large main residence, slave cabins, and outbuildings, which were often clustered together in a "gridlike pattern," known as the block plan. This configuration, identified by the geographer John B. Rehder, originated in the formal estates of Virginia and South Carolina. Other plantations were characterized by scattered outbuildings, or slave quarters that were far from the main house and closer to agricultural fields (Vlach 1993:6). As defined by landscape historians (Turner 1982:62), typical features included: 
1. Cultivated fields occupying the majority of the site;

2. The residence of the planter located in a prominent position;

3. Slave quarters clustered in a nodal or linear village form;

4. A highly developed service area near the planter's house, including a kitchen, woodpile, smokehouse, and other necessary utility areas;

5. A kitchen garden, usually sizeable, for the cultivation of foodstuffs for consumption by the planter's family and the slave population;

6. A transportation link with the market for the cash crop, whether a waterway or roadway; and

7. Ornamental planting, either an actual garden or simply rows of trees.

Regardless of placement, the elements were often coordinated to convey planter prestige, as well as a hierarchy of power. The austere nature of slave quarters, for example, was meant to remind inhabitants of their role within the plantation. Planters, displaying their wealth, adorned their residences with elaborate architectural detailing. An earlynineteenth-century account of Josiah Bell's plantation near East Columbia provides a vivid sense of a typical Brazoria County plantation landscape:

The entrance to the premises was from the north. Directly in front of the dwelling a stile over the lane fence admitted persons. A little further west a pair of bars admitted animals and carriages. The dwelling was about 200 yards west of the public road. West of the dwelling, some little distance from it, were the stock lots joined to the lane fence. In one of these were cribs for corn and the stables for horses. Between these and the house were the negro quarters, the blacksmith-shop, the smoke-house and the kitchen. These last were near to each other, and the kitchen only a few steps from the west end of the house....The dwelling was a double log house of the style very much used in all the early settlements in the United States [McCormick 1897:113-114].
The following section will explore in further detail how planter and slave housing, as well as outbuildings were situated within the overall plantation landscape in Brazoria County.

\section{Housing}

As discussed previously, homesites were selected according to their proximity to a river, stream, or creek. Early settlers like James B. Bailey and Josiah H. Bell erected log cabins which suited the frontier nature of early Brazoria County (see Figure A-12). By the mid-1840s, however, planters began to build more elaborate and permanent structures that served to display their growing wealth. The main house, or "big house," served as the epicenter of a social hierarchy that spread throughout the plantation (see Figure A-13).

Slave housing typically followed the same evolution as the main houses, moving from log cabins to frame or brick construction and were usually bare of any comforts (see Figure A-14). Though small in size, they typically housed an average of four to eight slaves. ${ }^{15}$ The location of slave housing usually depended upon the type of work slaves performed, with house slaves usually living in clustered quarters near the big house. Figure A-11 illustrates such a configuration. Field slaves, however, were usually a quarter mile or more away from the main house and were situated near agricultural fields. On large plantations, it was not uncommon to see clusters of slave housing adjacent to each cotton or sugar field (Curlee 1932:238). Figure A-15 shows the plan of a typical sugar plantation in which the slave quarters are situated in rows next to the cane fields. Some plantations like Bernardo in Brazoria County included slave communities that functioned like self-sufficient units, with tightly clustered slave quarters, a nursery building, and an overseer's house (see Figure A-16).

\section{Outbuildings}

Plantation outbuildings included kitchens, smokehouses, blacksmith shops, barns, stables, dairy houses, corn cribs, and pig houses. They were usually located near the main house-one architect commented that outbuildings surrounded southern homes "as a litter of pigs their mother." The arrangement of the outbuildings typically followed a linear arrangement (Vlach 1993:77-78). Figure A-12 shows such an arrangement of outbuildings.

Ginhouses and sugar mills were usually located near cotton or cane fields to facilitate the processing stage of cultivation.

${ }^{15} 1860$ Slave Schedule, Texas State Library and Archives, Austin, Texas. 


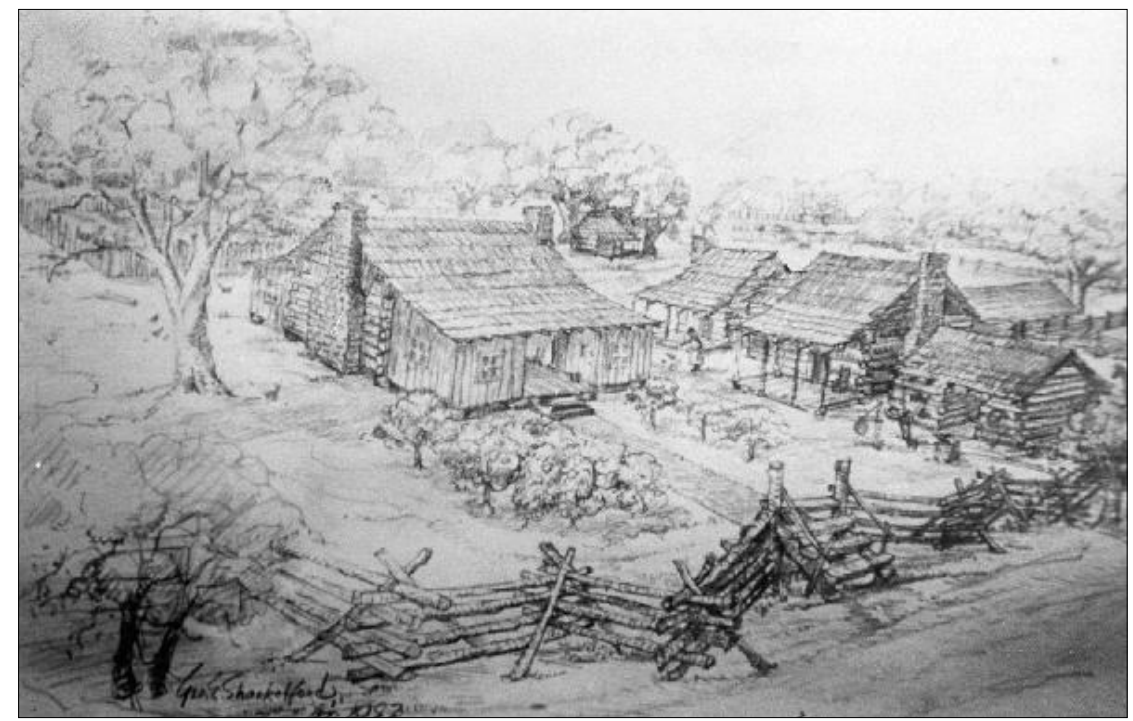

Figure A-12. Drawing showing the Josiah Bell plantation, Brazoria County, circa 1830. Source: Brazoria County Historical Museum.

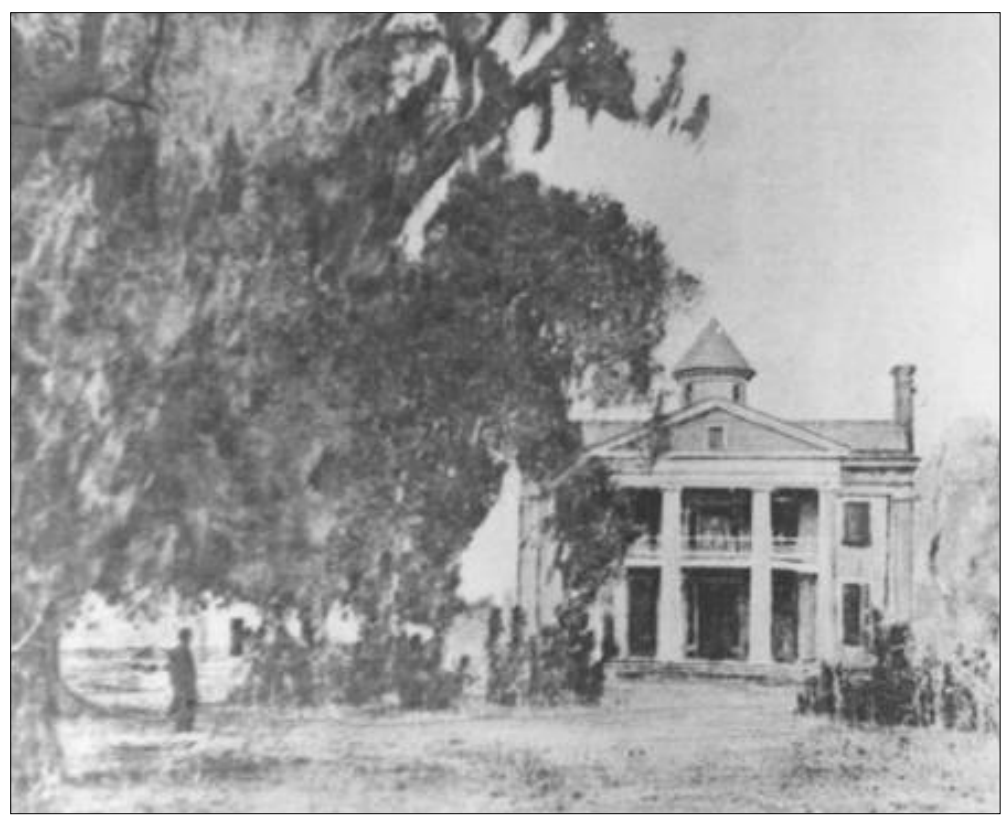

Figure A-13. Abner Jackson's plantation home at Lake Jackson, Brazoria County. Source: Brazoria County Historical Museum.

Unlike ginhouses, which were usually small frame buildings, sugar mills dominated the landscape with their brick construction, two-story height, and towering furnaces. Figure A-15 shows a sugar mill adjacent to the cane fields. Ginhouses and sugar mills were also situated close to roads, rivers, or railroads to ease the shipment of the bales of cotton and hogsheads of and sugar. An early-nineteenth-century account of Josiah Bell's plantation describes an example of how planters designed the relationship between public roads, agricultural machinery (ginhouse), and cotton fields: 
The relative situation of the fields to the dwelling house and to each other were the same, though each of the fields had been enlarged from time to time, as he added to his force of slaves. There were two main fields; the one extending north from the dwelling towards the prairie, called the prairie field, though little, if any, of it was prairie land; the other extending south, and called the lower field. Both these were west of the public road from Velasco through Brazoria and Columbia to San Felipe, which ran along the east fence of both, throughout the length of each, in a course nearly north and south. These fields were separated from each other only by an open lane, running at right-angles to the public road, and about one hundred yards north of the dwelling. There was a third field east of the public road and north of the line of the lane which separated the other two. This field was called the gin field, because in the southwest corner of it stood the cotton gin house [McCormick 1897:112-113].

The golden era of economic growth experienced by Brazoria County planters faltered with the arrival of the Civil War. The period of Reconstruction firmly ended the plantation period in Brazoria County and Texas.

\section{The Civil War and Reconstruction in Brazoria County}

Agriculture dominated life in antebellum Brazoria County and as a result, national matters received scant attention. By 1860 , however, the national debate over slavery was reaching a fever pitch throughout the state. Though Sam Houston, a unionist, was elected governor in 1859, a rising chorus of pro-secessionist voices, including prominent planters in Brazoria County, brought the issue to the forefront. On February 11, 1861, the population of Texas voted to secede from the Union, with $99 \%$ of Brazoria County residents voting for secession.

Compared to most southern states, Texas remained relatively untouched during the war. Aside from Union attacks on fortifications at Velasco and Quintana, and a federal blockade of the Texas coastline, the county saw little damage. The enlistment of much of the white male population of the county, however, had a tremendous effect on the agricultural output of the county. Plantation wives were forced to take over plantation operations, at the same time surviving constant shortages of food, materials, and labor (Kleiner 2003a).

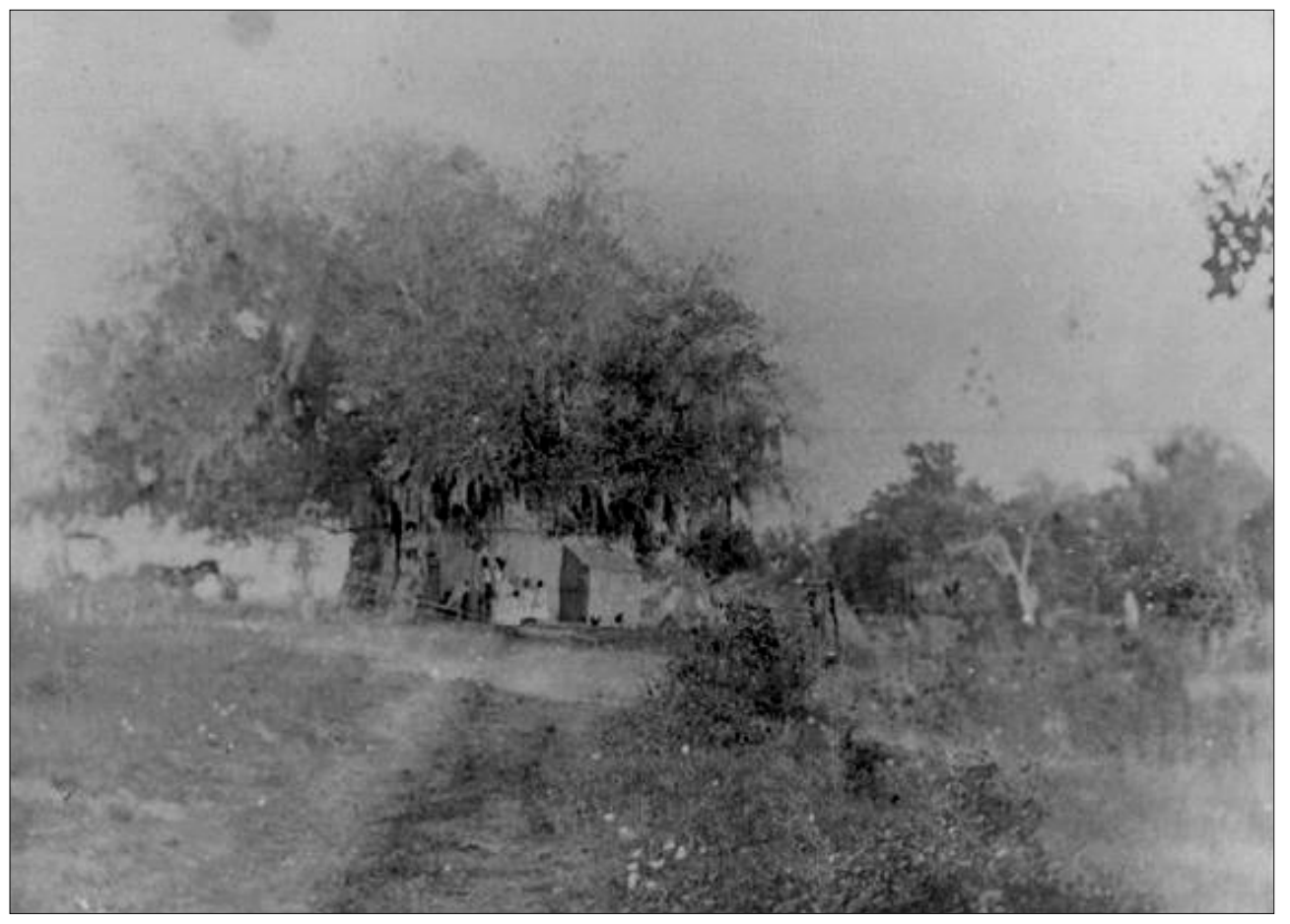

Figure A-14. Slave cabin at Ridgeley Plantation, Brazoria County.

Source: Brazoria County Historical Museum. 


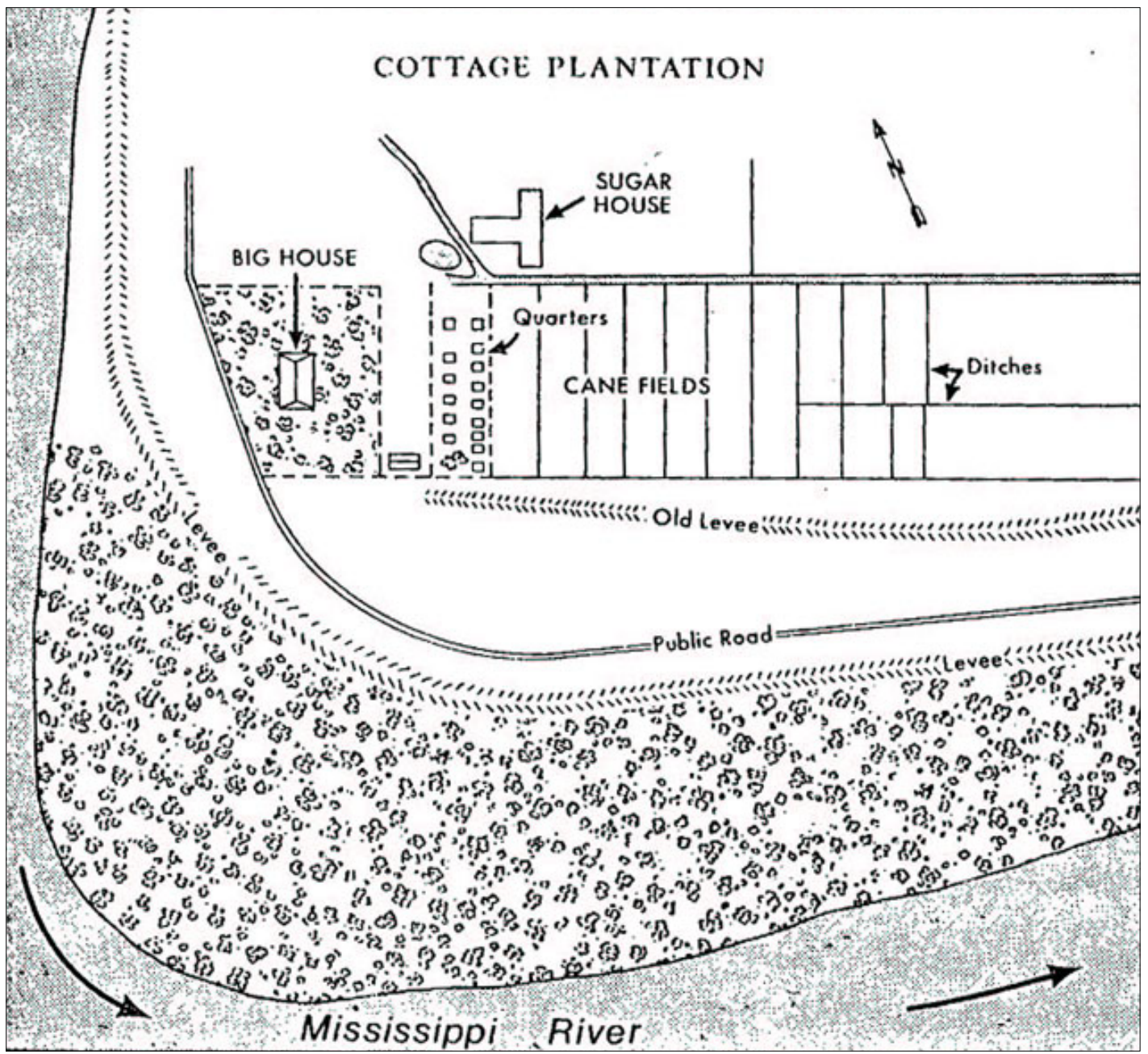

Figure A-15. Typical sugar plantation layout showing location of slave quarters.

Source: Hilliard (1979:265).

The economic hardships of the war, however, paled in comparison to the immediate changes brought by the Reconstruction era. On June 19, 1865, General Granger, the commander for the District of Texas, formally announced the liberation of all slaves in the state. The order devastated planters across the county. The average slaveholder in the county lost $\$ 11,980$ when the slaves were freed. Some large slaveholders, like brothers David and Robert Mills, were financially ruined. Land values plummeted by a third by 1866; by 1870, values had dropped by two-thirds from their pre-war level. Overall property values fell from $\$ 7$ million to $\$ 2$ million from 1860 to 1866 (Kleiner 2003a; Powers 1994:93).

Without a suitable form of labor, many plantations across the county split into smaller farms. Fields, once overflowing in cultivated cotton and sugar, were converted to pasture land. Some planters simply escaped the new reality and fled to Mexico. For some Brazoria County planter families, the Tuxpan River Valley in Vera Cruz served as the new home for their plantations (Kleiner 2003a). Planters who stayed in the county faced a complete upheaval of their world.

Life for the freedmen was not much better. Though free, many met the news of their freedom with confusion-Texas' isolation during the war kept many slaves ignorant of national events. Freedom for many slaves meant uncertainty. Without marketable skills outside of agriculture, many freedmen saw little change in their future. Planters reacted differently to the news of their slaves being freed, with some accepting the news, and others determined to keep the new freedmen in a state of economic servitude. 


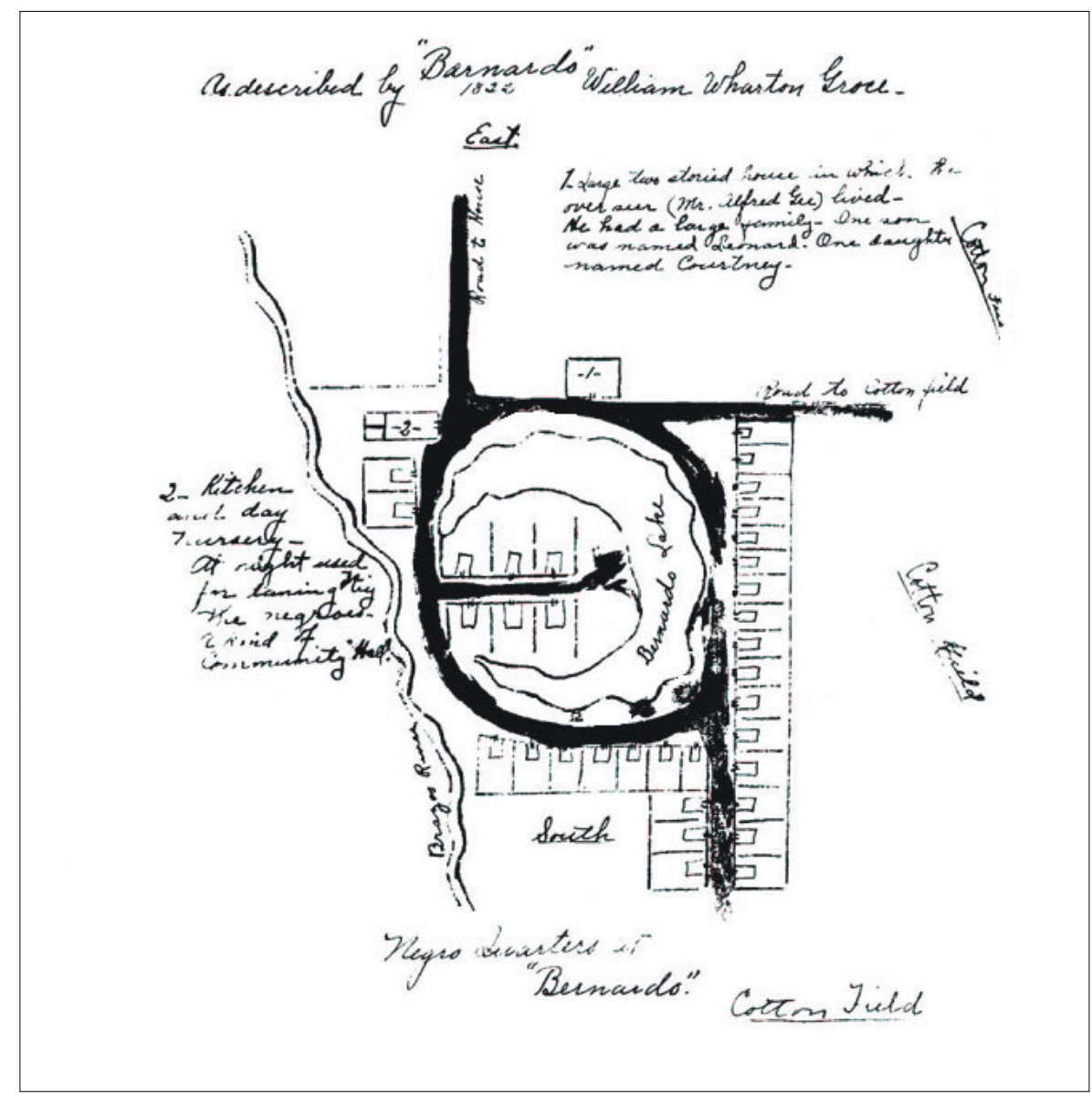

Figure A-16. Slave community at Bernardo Plantation, Brazoria County. Source: Curlee (1932).

\section{The Wage System and Sharecropping in Brazoria County}

Labor shortages in the Reconstruction era plagued the planters. Months after being freed, some slaves refused to work, others exhibited a lack of interest in cultivating their former master's lands. Some Brazoria County planters turned instead to Europe as a source for cheap labor. A small number of British, French, and Swedish peasants arrived in the county to work on the plantations, but soon quit because of low pay (Dorsett 1981:100). As a result, planters realized that freedmen were the only way to continue agricultural pursuits.

The Freedmen's Bureau, a national organization whose Texas branch opened in November 1865, attempted to facilitate planter and freedmen work relationships. To satisfy the freedmen, the Bureau limited the work day for male freedmen to ten hours. In addition, work contracts had to be certified by the Bureau before being instigated. Planters adopted the wage system in the months after the war. Wages for a month's work averaged $\$ 2$ to $\$ 10$. Freedmen disliked the wage system, as some planters were determined to pay as little as possible (Smallwood 1981:43-43).

After months of using the system, both planters and freedmen were eager to find a new arrangement. Planters realized that freedmen would work harder if they felt a level of ownership over crops and as a result, the county adopted a tenant farming or sharecropping system. Sharecropping provided freedmen with several options. If planters made available supplies and housing, freedmen received one-third or onefourth of the crops grown. Laborers that provided their own supplies received half of all crops. Sharecropping proved favorable to many freedmen by giving them a sense of 
ownership and freedom that the wage system did not. The labor contracts created between planters and freedmen were specific as to the terms of agreement which can be seen in the following labor contract between Brazoria County planter John Sweeney, Jr. and four freedmen:

This contract made and entered into this $1^{\text {st }}$ day of January 1868 between John Sweeney part of the first part and the undersigned freedmen parties of the second part for the cultivation of 120 acres witnesseth - That John Sweeney in his part agrees to furnish land, team and farming implements and feed for the same and to give the parties of the second part two-fifths of all the crops raised on said 120 acres. Except sweet potatoes of which they are to have half.

The parties of the second part agree to thoroughly cultivate the land assigned to them and gather and house the crop being at all times subject to the orders of said Sweeney as far as the kind of crop to be planted and the manner of cultivating the same.

They further agree to feed themselves and Mr. Sweeney on his part agrees to furnish bacon at the usual price- 15 cents a pound to be paid out of their crop. They further agree that should they neglect their crop they will be liable to damages the amount to be decided by two disinterested parties one chosen by each party or by the agent of the Freedman's Bureau. This contract is to terminate when the crop is housed or divided. ${ }^{16}$

Though sharecropping provided freedman with increased autonomy over their lives, the reality for many was dire. If crops failed, freedmen were held responsible, thereby forcing many into debt. This form of dependence prevented many from breaking the cycle of poverty. Sharecropping remained the dominant system of agriculture throughout the state for the rest of the nineteenth century (Smallwood 1981:44-45).

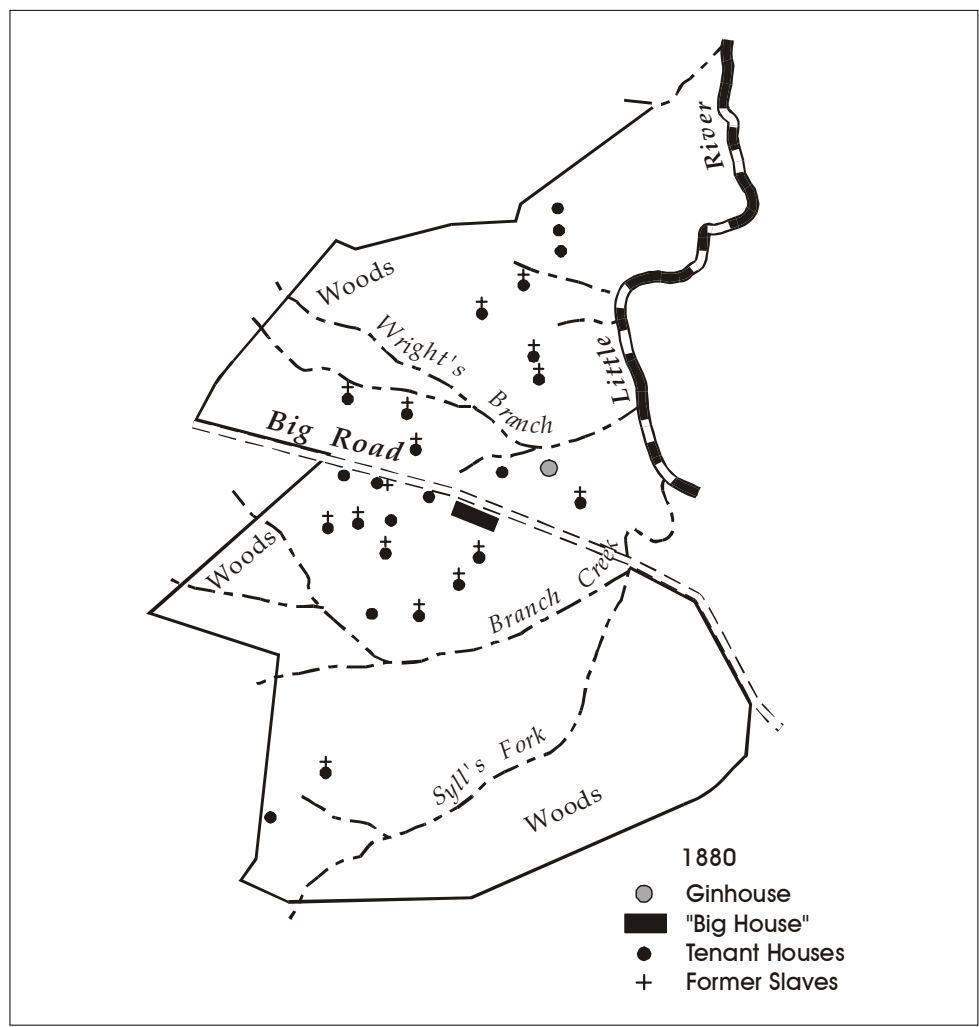

Figure A-17. Postbellum settlement patterns indicative of the sharecropping system. Source: Iruegas (2003); redrafted.

\footnotetext{
${ }^{16}$ Brazoria County Historical Museum Archival Collections, Angleton, Texas.
} 
With the breakup of many plantations and the introduction of sharecropping, agricultural settlement patterns changed in the postbellum period. Tenant farming allowed freedmen to manage independent farmsteads rather than work in large groups as in the antebellum era. Tenant housing as a result was scattered across cultivated lands, rather than clustered in groups. Figure A-17 shows the settlement patterns of freedmen as they appeared in the postbellum era. Figure A-11 shows the antebellum period of clustered slave housing.

While the vast majority of Brazoria County freedmen remained stuck in the economic trap of sharecropping, a few managed to own land and maintain a level of success unknown to most former slaves. The freedman Charlie Brown emerged as the "wealthiest negro in Texas," shortly after the war. By the time of his death in 1920, Brown owned roughly 3,200 acres in Brazoria County. Nelson Crosby, also a freedman, raised cattle and horses successfully on land received by his parents from their former owners. Overall, 33 of the 1,332 freedmen families in Brazoria County owned land, a number indicating the tremendous economic barriers freedmen faced after the war. Other freedmen found positions of authority during the Republican-controlled Reconstruction era; however, the rising power of white vigilante groups like the Ku Klux Klan in 1866, limited such roles for blacks (Creighton 1986:261-264). In fact, options for most freedmen after 1866 were few indeed. Brazoria County leaders passed Black Codes that severely limited the economic, social, and political roles for freedmen (Smallwood 1981:54).

\section{Freedmen Communities in Brazoria County}

Despite the economic hardships associated with postwar Brazoria County, freedmen were eager to establish their cultural and religious independence. As part of this trend, freedmen communities across the state formed in the postwar years. The sites of these communities varied, with some forming on lands previously occupied by plantations and others developing on the outskirts of towns or cities.

Upon gaining their freedom, blacks across the state began to pursue educational and religious opportunities. With help from the Freedmen's Bureau, freedmen were moderately successful at establishing schools. Shortly after, churches were formed and included congregations made up of exslaves. In the majority of cases, freedmen rejected the congregations formed by their former masters and instead established their own services. These educational and religious developments grew into distinct communities of ex-slaves. For freedmen engaged in tenant farming, the new communities often developed on former plantation lands. Others tried urban areas for economic opportunities. In fact, the state witnessed a large migration to towns after the war, with one witness stating that freedmen wanted "to get closer to freedom, so they'd know what it was-like it was a place or a city" (Smallwood 1981:28). Houston, San Antonio, Austin, and Gonzales were all towns that witnessed the arrival of large groups of freedmen. As a result, these towns saw the gradual formation of freedmen communities.

The establishment of ex-slave communities in Brazoria County followed similar patterns as those that formed in the rest of the state. However, due to the lack of archival materials, a detailed understanding of the county's freedmen communities is not possible. Despite the lack of information, some trends can be established. Like counties in the rest of the state, Brazoria County witnessed the formation of numerous freedmen churches. One church was formed at Waldeck Plantation and included former slaves from the site. Other churches, the majority of which were Baptist, formed on the outskirts of small towns like East Columbia and Brazoria. Jerusalem Baptist Church, St. Paul Baptist Church and Bethlehem AME were examples of the roughly 13 freedmen churches in the county. It can be safely assumed that the location of the churches indicates where possible freedmen communities may have been located. Some Brazoria County freedmen were also likely to have been part of the migration to urban areas like Houston.

Recently, a freedmen cemetery was discovered at the site of the former Ebenezer Baptist Church near Bailey's Prairie. In addition to demonstrating the presence of freedmen communities in the county, the discovery also shows how much of the freedmen's history remains unknown (Angleton Times, 11 July, 1985).

\section{Agriculture in the Reconstruction Era, Brazoria County}

The economic hardships planters faced following the Civil War worsened when agriculture failed to spring back to prewar yields. The lack of labor and a depressed southern economy devastated agriculture in the county in the immediate postwar years. Crops during the period remained the same: corn, grain, sweet and Irish potatoes, fruits, cotton and sugar. Hardest hit was the sugar industry, which required a large supply of laborers. In 1867, one sugar planter 
commented: "the present crops are but about half an average, owing entirely to the impossibility of getting the negroes to work, for the season has been one of the best ever known" (Johnson 1961:40). Brazoria County produced only 1,423 hogsheads of sugar in 1869.

It was not until 1871 that the sugar industry returned to production levels consistent with prewar levels. The reason for the change was the use of convict labor, which the Texas legislature allowed in 1871. Plantation owners now had the option of leasing convicts to work on their sugar plantations. Planters viewed convict labor as more dependable than freedmen labor. The convict lease system significantly expanded in the $1880 \mathrm{~s}$; by the $1890 \mathrm{~s}$, former plantations, like Retrieve and Darrington, became state prison farms (Johnson 1961:41).

Though cash crops like cotton and sugar showed signs of improvement by 1870 , cattle ranching emerged as an important component of economic life in Brazoria County. Many planters turned to ranching as a more stable pursuit in the postwar years and prospered as a result of the national market for beef (Murray 1940). Brazoria County was also home to an emerging canning industry - over $\$ 100,000$ of canned beef was produced in 1870 (Kleiner 2003a).

\section{Oil, Sulfur, and Petrochemical Developments in Brazoria County}

Agriculture remained the dominant economic activity in Brazoria County until the emergence of oil and sulfur deposits in the early twentieth century. Oil production in the county began in 1902 after an oil field was discovered in West Columbia the year before. Production reached 12,500,000 barrels in 1921. By 1946, the county produced 29,308,106 barrels, making it the fourth largest producer among Texas counties. In 1906, a mining engineer, Bernard Baruch, discovered a sulfur mound along the Gulf of Mexico shoreline in Brazoria County. In 1912, using a recently developed sulfur mining technology, the newly organized Texas Freeport Sulphur Company began mining the sulfur mound, which became known as the Bryan Mound. Other sulfur deposits like Hoskins Mound and Stratton Ridge Dome emerged in later years and provided an economic boost to the region.

The sulfur industry in Brazoria County ranked first in U.S. production and made significant contributions to both world wars. In 1930, the Freeport Sulphur Company was extracting 2,000 tons of sulfur daily at the Bryan and Hoskins Mounds. By the end of World War II, sulfur mining in the county had been depleted; nonetheless, the company extracted 552,000 long tons of ore by 1944 (Kleiner 2003a). Figure A-18 displays a circa 1940 map that locates oil and sulfur deposits throughout the county.

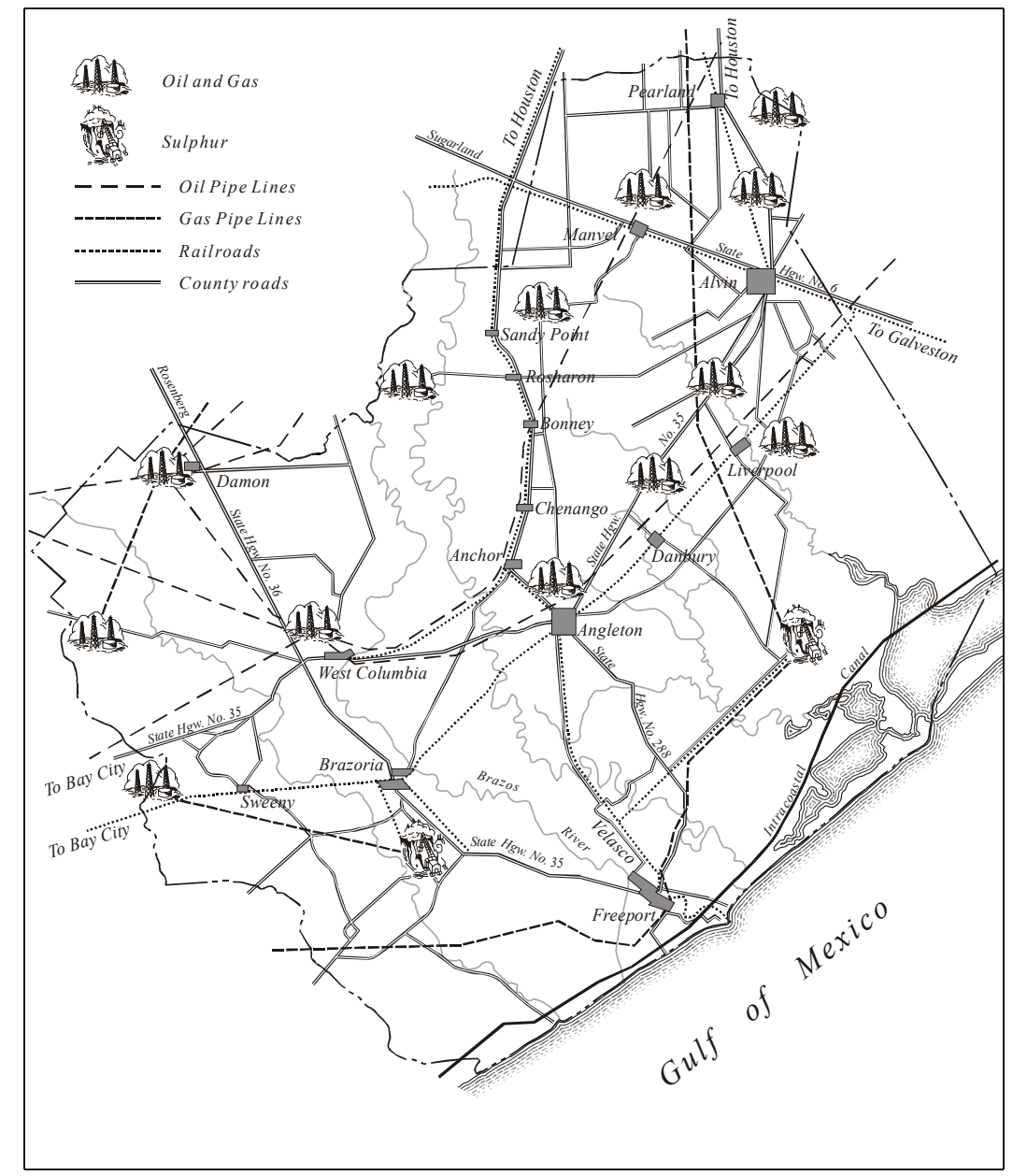

Figure A-18. Oil, gas, and sulfur deposits in Brazoria County, circa 1940. Source: Brazoria County Historical Museum; redrafted from copy. 
Despite the decline of the sulfur industry, Brazoria County in 1939 was fortunate to benefit from Dow Chemical Company's move to Freeport, which added the petrochemical industry to the economic portrait of the county. The company quickly made an impact through its contributions to the war effort. In 1941, the Dow Chemical plant at Freeport began the commercial production of magnesium using sea water processed through electrolysis. The large production of magnesium proved vital for defense purposes and was used in airplanes, transportation, and textile industries. Shortly after, Dow expanded its magnesium production by creating a plant at Velasco, which also had easy access to sea water. The two plants combined produced 92,000 short tons of magnesium a year, in addition to producing refractory magnesia, magnesium chloride, caustic-calcined magnesia, and magnesium hydroxide. As a result, Brazoria County was responsible for more than $84 \%$ of the nation's production of magnesium. In the following decades, magnesium production at Dow continued at a fast pace (Kleiner 2003b).

As part of Dow's presence in Brazoria County, the community of Lake Jackson was established by the company in 1942 on plantation land formerly owned by Abner Jackson. The community grew quickly and today is one of the county's largest cities. During the war, Dow Chemical began the process of connecting its main plant at Freeport with outlying oil fields. The importance of oil and gas to their operations forced Dow to create an infrastructure easing its connections to oil and gas deposits. As a result, oil and gas pipelines running from deposits such as Old Ocean to Freeport began appearing at a fast rate. The old Bryan and Hoskins sulfur mounds were also tapped for their oil and gas as well. The new infrastructure eventually resulted in the formation of a new oil and gas branch of Dow called the Brazos Oil and Gas Division (Brandt 1997:186-187).

The Old Ocean oil field, discovered in 1934, was located near Sweeny, Texas, which in 1947 became the new location for a Phillips Petroleum plant. The company built a refinery, natural gas liquids center, and petrochemical complex at the site. Phillips remains a major employer of the region.

The shift from an agricultural-based to an industry-led economy significantly altered the physical landscape of the county. Several former plantation sites were discovered to later contain significant oil and sulfur deposits, including the Varner-Hogg Plantation site north of West Columbia. In 1990, Phillips Petroleum purchased the last plantation site owned by the same family since the antebellum period. The Sweeny plantation site included the original residence, and a slave cemetery in what is today Old Ocean. The site is currently surrounded by petrochemical plants and refineries. ${ }^{17}$ The Lake Jackson Plantation, of course, was later turned into Dow's company town, Lake Jackson. While some portions of former Brazoria County plantation land remain untouched by development and the petrochemical industry, many areas of the county have been adversely affected in past decades.

17 “John Sweeny," Vertical Files, Brazoria County Historical Museum. 


\section{References Cited}

Angleton Times

1985 “Old Cemetery Link to Past.” 11 July.

Brandt, E. N.

1997 Growth Company, Dow Chemical's First Century. Michigan State University Press, East Lansing.

Campbell, R. B.

1989 An Empire for Slavery-The Peculiar Institution in Texas, 1821-1865. Louisiana State University Press, Baton Rouge.

Champomier, P. A.

1852/53 Statement of the Sugar Crop made in Louisiana in 1852-53. New Orleans.

Creighton, J.

1986 A Narrative History of Brazoria County. Brazoria County Historical Commission.

Curlee, A.

1932 A Study of Texas Slave Plantations, 1822 to 1865. Ph.D. dissertation, The University of Texas at Austin.

Dorsett, J.

1981 Blacks in Reconstruction Texas, 1865-1877. Ph.D. dissertation, AddRan College of Arts and Sciences.

Few, J.

1994 Sugar and Cotton Production in the Texas Sugar Bowl. In Antebellum Texas, Brazos Style, 1994 Session. Brazoria County Historical Museum, February 26, 1994.

Harris, R.

2003 “David Graham Mills." The Handbook of Texas Online. < http://www.tsha.utexas.edu/handbook/online/articles/ view/MM/fmi64.html> Accessed September 2003.

Hilliard, S.

1979 Site Characteristics and Spatial Stability of the Louisiana Sugarcane Industry. Agricultural History 76.

Iruegas, S. A.

2003 Plantation Settlement Patterns: Landscapes in Plantation Archeology. Manuscript on file Texas Historical Commission, Austin.

Johnson, W.

1961 A Short History of the Sugar Industry in Texas. Texas Gulf Coast Historical Association Publications.

Kleiner, D. J.

2003a "Brazoria County." The Handbook of Texas Online. <http://www.tsha.utexas.edu/handbook/online/articles/view/ BB/hcb12.html> Accessed September 2003.

2003b "Magnesium Industry." The Handbook of Texas Online. <http:/www.tsha.utexas.edu/handbook/online/articles/ view/MM/dkm1.html> Accessed September 2003. 
Lowe, R. G., and R. B. Campbell

1987 Planters and Plain Folk, Agriculture in Antebellum Texas. Southern Methodist University, Dallas.

McCormick, A. P.

1897 Scotch-Irish in Ireland and in America. New Orleans.

Murray, M.

1940 Home Life on Early Ranches of Southwest Texas. The Cattleman (November 1940).

Platter, A. A.

1961 Educational, Social, and Economic Characteristics of the Plantation Culture of Brazoria County, Texas. Unpublished Ph.D. Dissertation. College of Education, University of Houston.

Powers, B. J.

1994 From Cotton Fields to Oil Fields: Economic Development in a New South Community, 1860-1920. Ph.D. dissertation, University of Houston.

Roell, C. H.

2003 “Charles D. Sayre.” The Handbook of Texas Online. <http://www.tsha.utexas.edu/handbook/online/articles/view/ SS/fsa43.html> Accessed September 2003.

Smallwood, J. M.

1981 Time of Hope, Time of Despair-Black Texans During Reconstruction. Kennikat Press, Port Washington, New York.

Strobel, A. J.

1930 The Old Plantations and their Owners of Brazoria County, Texas. The Union National Bank, Houston, Texas.

Texas Department of Agriculture

1909 Year Book 1909. Texas Department of Agriculture Bulletin. Von Boeckmann-Jones Company, Austin.

Tuffly, E. L., T. G. Jordan, and J. R. Buchanan.

1976 Cultural and historical maps of Texas from the Atlas of Texas. Bureau of Business Research, University of Texas at Austin.

Turner, S.

1982 Exploring the Landscape Design of Antebellum Plantations. Texana II: Cultural Heritage of the Plantation South. Texas Historical Commission, Austin.

Vlach, M.

1993 Back of the Big House - The Architecture of Plantation Slavery. University of North Carolina Press, Chapel Hill.

Weir, M.

2003 “James Briton Bailey.” The Handbook of Texas Online. $<$ http://www.tsha.utexas.edu/handbook/online/articles/ view/BB/fba8.html> Accessed September 2003.

White, R. E.

1957 Cotton Ginning in Texas to 1861. Southwestern Historical Quarterly vol. 61. 
Williamson, T. A.

1987 The Munsons of Texas: An American Saga. Privately published, T. A. Williamson, Dallas, Texas.

Wooster, R. F.

1961 Notes on Texas' Largest Slaveholders, 1860. Southwestern Historical Quarterly 65:72.

\section{Additional References Consulted}

Brown, K. L.

1994 Material Culture and Community Structure: The Slave and Tenant Community at Levi Jordan's Plantation, 18481892. In Working Toward Freedom: Slave Society and Domestic Economy in the American South. University of Rochester Press, Rochester, New York.

Campbell, R. B., and R. G. Lowe.

1977 Wealth and Power in Antebellum Texas. Texas A\&M University, College Station.

1979 Some Economic Aspects of Antebellum Texas Agriculture. Southwestern Historical Quarterly 82.

Debow's Review, Agricultural, Commercial, Industrial Progress and Resources

1948 “Sugar Manufacture.” Issues 4-5, October-November.

Holbrook, A. C.

1973 A Glimpse of Life on Antebellum Slave Plantations in Texas. Southwestern Historical Quarterly 76.

Roark, J. L.

1977 Masters Without Slaves: Southern Planters in the Civil War and Reconstruction. W.W. Norton \& Company, New York.

Wooster, R.

1967 Wealthy Texans, 1860. Southwestern Historical Quarterly 71. 
